Observations on a Scrapbook Attributed to John Thomson at George Eastman House

by

Bing Wang

Bachelor of History,

Nankai University, Tianjin, China, 2009

A thesis

presented to Ryerson University \&

George Eastman House International Museum of Photography and Film

in partial fulfillment

of the requirements for the degree of

Master of Arts

in the Program of

Film and Photography Preservation \& Collections Management

Toronto, Ontario, Canada \& Rochester, New York, USA, 2014

(C) Bing Wang 2014 


\section{Author's Declaration}

I hereby declare that I am the sole author of this thesis or dissertation.

I authorize Ryerson University to lend this thesis to other institutions or individuals for the purpose of scholarly research.

I further authorize Ryerson University and George Eastman House International Museum of Photography and Film to reproduce this thesis or dissertation by photocopying or by other means, in total or in part, at the request of other institutions or individuals for the purpose of scholarly research. 


\title{
Observations on a Scrapbook Attributed to John Thomson at George Eastman House
}

\author{
By
}

Bing Wang

\begin{abstract}
This thesis comprises a description and analysis of a personal scrapbook with 123 albumen prints compiled in the nineteenth century. Originally attributed to photographer John Thomson (1837-1921), it is held by George Eastman House, International Museum of Photography and Film. The goal of this thesis is to critically examine the original catalogue records and provide more appropriate and searchable catalogue information in the Eastman House's collection management system.

Histories of photography in Asian countries featured in the scrapbook, and an account of Thomson's career contextualize the scrapbook. A detailed analysis of this scrapbook focuses on the attribution and subjects of the photographs and the compiler of the scrapbook. While the attributions for all the images can not be confirmed, this thesis provides more accurate and reliable information about this scrapbook and, therefore, paves the way for future research on this scrapbook and the history of the nineteenth-century Far East photography.
\end{abstract}




\section{Acknowledgements}

This thesis would not have been possible without the support, guidance, and advice of several individuals who, in one way or another, contributed their invaluable input towards the completion of this research.

First and foremost, I would like to thank my supervisor, Dr. Bruno Lessard, for his time, patience, and understanding as the project developed over time. I would like to thank my second reader, Joe R. Struble, who helped me to decipher and analyze this intriguing nineteenth-century scrapbook of images from the Far East.

I owe huge thanks to Stephen White and Richard Ovenden, who kindly spared their time and knowledge to help me analyze this scrapbook and understand photographer John Thomson and his travels in the Far East.

I owe sincere gratitude to Professor David Harris, who shared his insight into photographer John Thomson and helped me through difficult times. I also owe many thanks to Mark Osterman, who guided my understanding of the wet collodion process and provided me with a better sense of the materiality of images in order to better appreciate them.

I would like to acknowledge the staff of George Eastman House, International Museum of Photography and Film, who have helped me carry out this project, in particular: Jessica Johnston, Jamie M. Allen, Barbara Puorro Galasso, Ross Knapper, and William Green.

The assistance of the following individuals and institutions also played an important role in the completion of my thesis: William Schupbach and the Iconographic Collections at Wellcome Library, London; Kirstin Kay and the Special Collections at the University of Massachusetts, Amherst; Dr. Nick Pearce, Professor at the University of Glasgow; and Dr. Heather S. Sonntag, Honorary Fellow at the University of Wisconsin-Madison.

Last but by no means least, countless thanks to my family, for their financial and emotional support through the years. 
Thousands of thanks to Ms. E., who is the one who not only inspired me to rethink my thesis but also the one who helped me survive through difficult times.

Thousands of thanks to A., you are the only reason why I am still standing here. 


\section{TABLE OF CONTENTS}

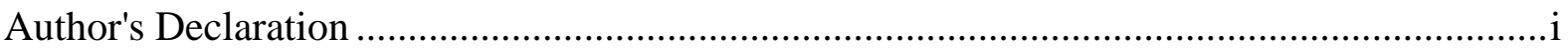

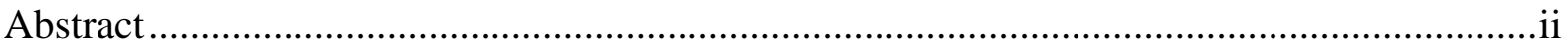

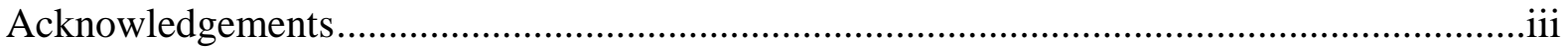

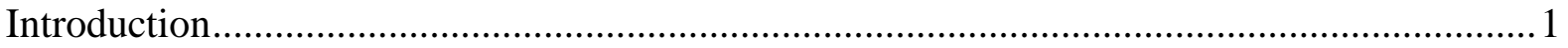

History of Photography in Malaysia, Singapore, Ceylon, India, and China............................. 3

I. History of Photography in Malaysia and Singapore (1843-1910) ....................................

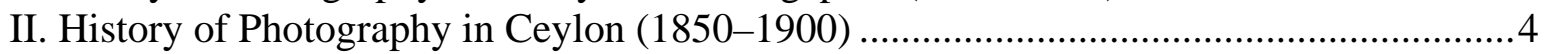

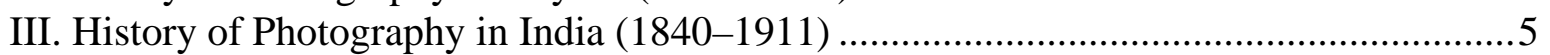

IV. History of Photography in China (1842-1900) ............................................................. 6

V. Photographer John Thomson and His Ten-Year Far East Sojourn .................................9

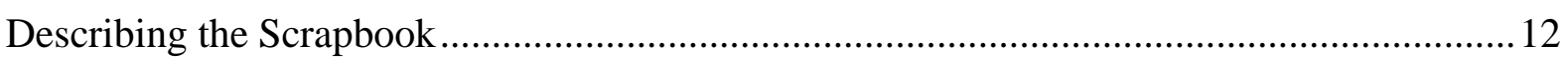

I. Physical Dimensions of the Scrapbook and the Print Process .......................................... 12

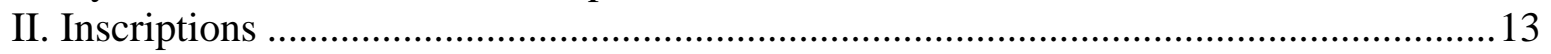

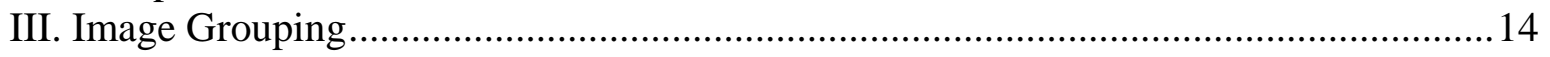

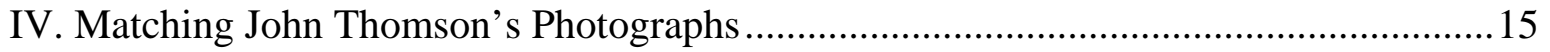

Debating Scholarly Arguments about Thomson................................................................. 17

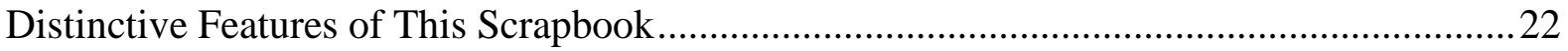

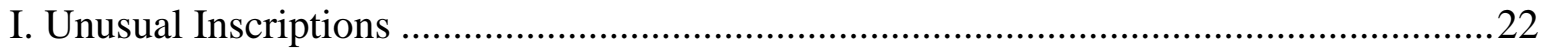

II. Photographs were not Made for Commercial Purposes ….........................................23

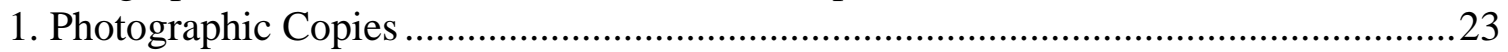

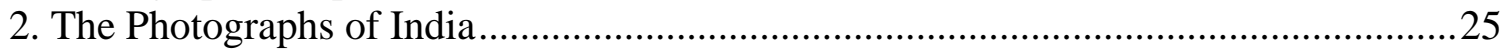

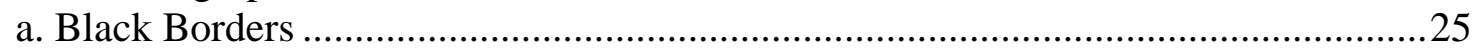

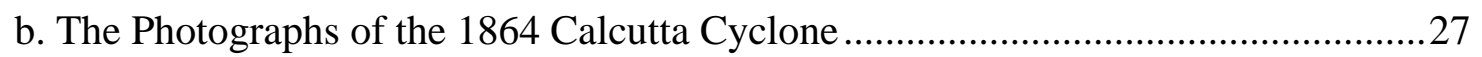

3. Photographer William Pryor Floyd and the Images of the Duke of Edinburgh's 1869

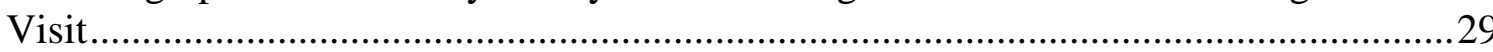

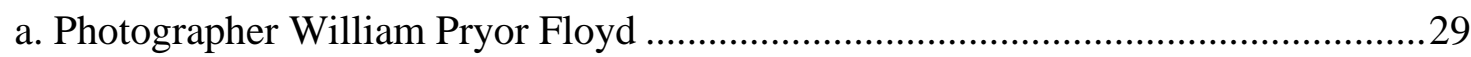

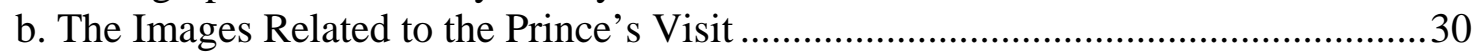

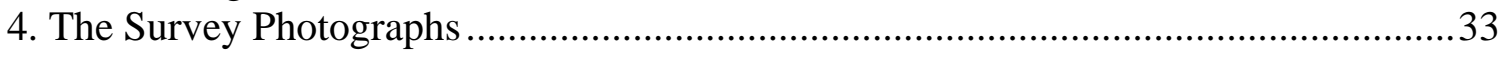

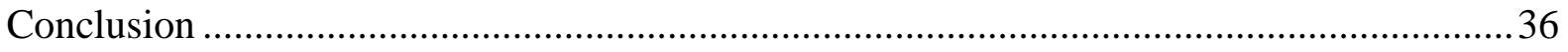

Appendix 1 The Different Numbering Systems and Inscriptions Present in This Scrapbook 39

Appendix 2 Comparing Handwriting ….......................................................................... 41

Appendix 3 Matching Results and Catalogues ........................................................................ 42

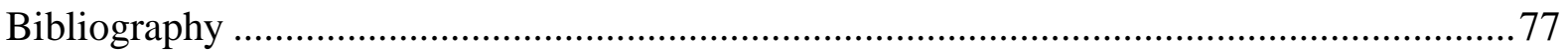




\section{List of Illustrations}

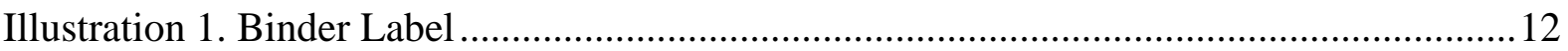

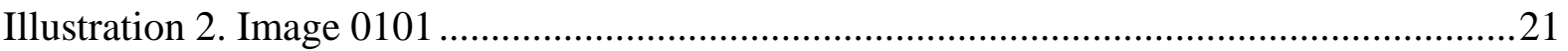

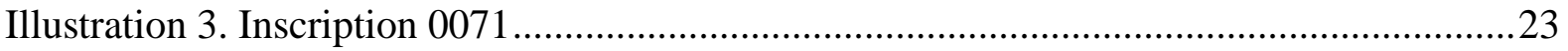

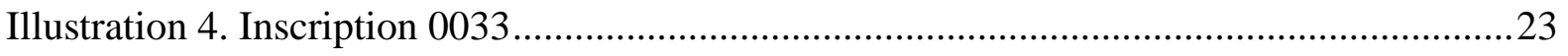

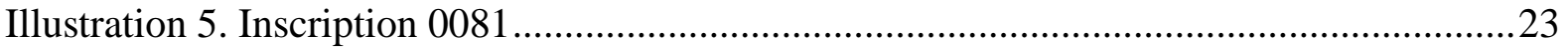

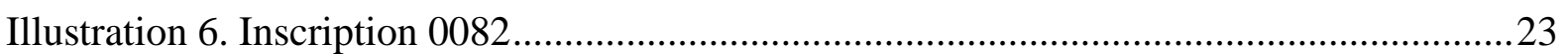

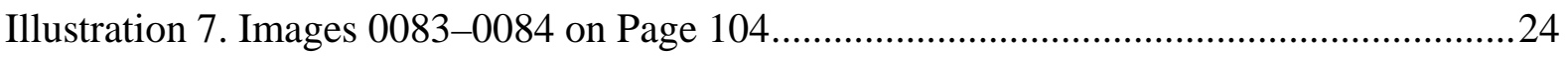

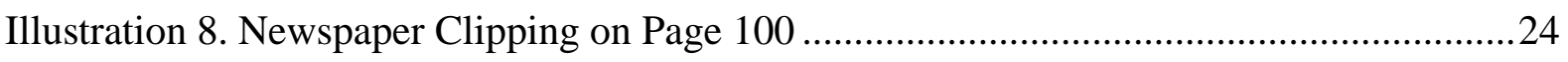

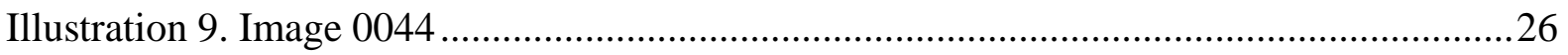

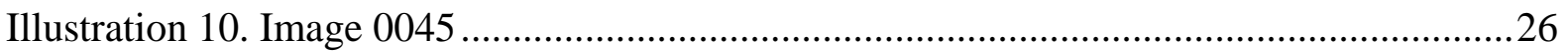

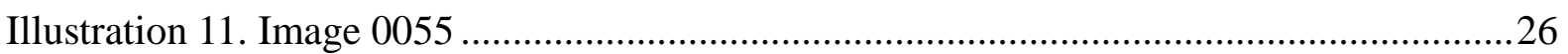

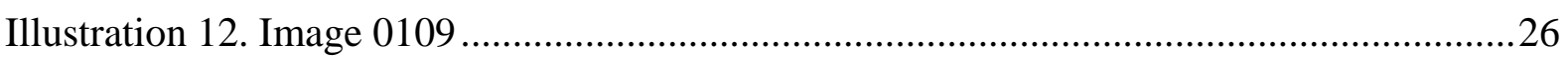

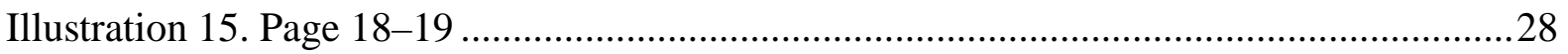

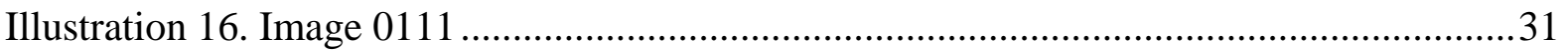

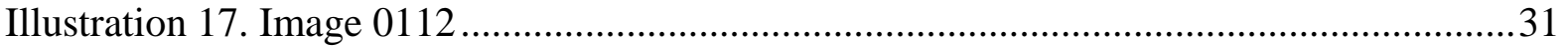

Illustration 18. Prince's Portrait in The Visit of His Royal Highness.......................................32

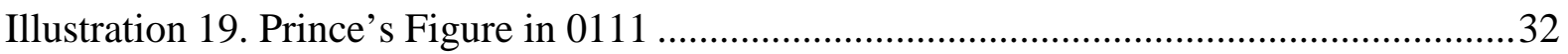

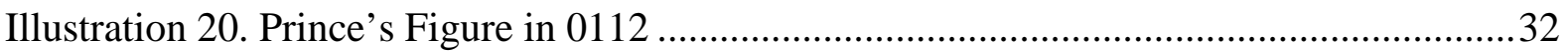

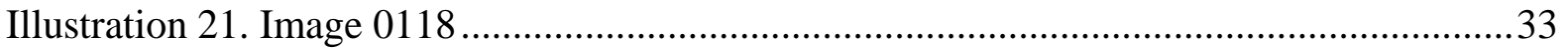

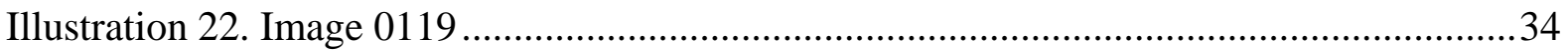

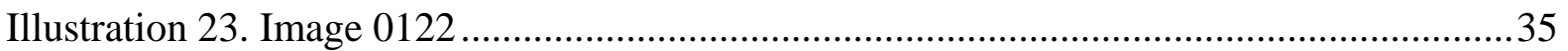




\section{Introduction}

In George Eastman House’s Photography Collection, there is a scrapbook catalogued by the former archivist, David Wooters, as "John Thomson Scrapbook."1 It belongs to the Boyer Collection, an important collection that includes more than 13,500 photographs received by the Eastman House from the American perfume manufacturer and photography collector, Alden Scott Boyer (1887-1953), in the 1950s. ${ }^{2}$

In the collection management system, Wooters lists three justifications for this scrapbook’s attribution to John Thomson (1837-1921): firstly, this scrapbook comprises nine photographs that were signed by John Thomson; secondly, five additional photographs were attributed to Thomson by Stephen White in his John Thomson: A Window to the Orient (1985); and thirdly, the content and sequence in the scrapbook parallel Thomson's travels in south-east Asia. ${ }^{3}$ Wooters further suggests that the album itself may have been Thomson’s personal scrapbook. ${ }^{4}$

However, this catalogue record does not provide adequate evidence to confirm the attribution. To date, within public collections, there is no photo album ${ }^{5}$ that has been identified to be exclusively the work of photographer John Thomson or that of his studio. Were the scrapbook held by the Eastman House proven to have been made by John Thomson, it would provide new solid evidence for researchers to understand this photographer and his travels in Asia. Therefore, this scrapbook deserves a closer analysis.

\footnotetext{
${ }^{1}$ George Eastman House's collection management system (object name John Thomson Scrapbook [accession number 1973:0219:0001-0123]; accessed November 8, 2013). Upon further research, I found out this attribution was made by Stephen White, a photography collector and the author of a book about John Thomson, when he visited George Eastman House in the early 1980s.

${ }^{2}$ George Eastman House, “The Boyer Collection," Image, Journal of Photography of the George Eastman House 2.7 (1953): 41-48; Eastman House's collection management system (constituents name Alden Scott Boyer [constituents number 8103]; accessed June 21, 2014), “Cultivated by Beaumont Newhall, Boyer sold and donated portions of his collection to the Eastman House in the early 1950s. The collection is among the largest and most significant holdings of IMP/GEH.”

${ }^{3}$ Eastman House’s collection management system (object name John Thomson Scrapbook).

${ }^{4}$ Ibid.

5 The "photo album" is a photographic album manually assembled by him or his studio rather than the illustrated books he published such as The Antiquities of Cambodia: A Series of Photographs Taken on the Spot and the Illustrations of China and Its People.
} 
This scrapbook has been viewed separately by Stephen White and Richard Ovenden, who have both written books about John Thomson. They come to two very different conclusions about the scrapbook's attribution. While Ovenden states that this is a "normal" souvenir scrapbook complied by an anonymous traveler, ${ }^{6}$ White attributes this scrapbook to Thomson. ${ }^{7}$

Starting with the controversial attribution, this thesis project includes both research and practical components. The research part is designed to provide a close study and understanding of the images in the scrapbook, and the practical part is designed to revise and complete the catalogue records in the Eastman House's collection management system. To contextualize this project, the thesis will first turn to brief histories of photography in Asian countries; then, it will describe the scrapbook in detail and explain why White's and Wooters' attribution no longer seem convincing. Finally, the thesis will discuss the distinctive features that the scrapbook contains. The practical focus of this project, that of the catalogue records of the attributable John Thomson prints, will be presented in the appendix.

\footnotetext{
${ }^{6}$ Richard Ovenden, e-mail message to author, March 29, 2014.

7 Stephen White, e-mail message to author, March 18, 2014.
} 


\section{History of Photography in Malaysia, Singapore, Ceylon, India, and China}

According to the inscriptions, the photographs in this scrapbook are of Malaysia, Singapore, Ceylon, India, and China and were taken in the latter half of the nineteenth century. To better understand the socio-cultural and commercial context of these photographs, this section will present a brief history of photography in these five countries during the nineteenth century.

\section{History of Photography in Malaysia and Singapore (1843-1910)}

The Malay Kingdom's states of Dinding, Malacca, Penang, and Singapore were the British Straits Settlements from 1826 until 1963, when Malaysia (Federation of Malaya, North Borneo, Sarawak, Singapore) was established. ${ }^{8}$ In 1965, Singapore announced independence from Malaysia. ${ }^{9}$ Hence, the history of Singapore before 1965, either the general history of the country or the specific history of photography, is inseparable from that of Malaysia.

As an important port for the East India Company, Singapore, as well as the entire Malayan mainland, was high on the list of places where Western travelers, including both general travelers and professional/amateur photographers, sought adventure in the Far East in the middle of the nineteenth century. However, the persistently cloudy skies and very humid weather made the area unsuitable for early photographic activities.

The only known photographic works produced in this country during the 1840s both date from $1843^{10}$ : Alphonse Eugène Jules Itier (1802-1877) took the earliest surviving photographs (daguerreotypes) of the Malayan mainland ${ }^{11}$, and Gaston Dutronquoy (c.

\footnotetext{
${ }^{8}$ Virginia Matheson Hooker, A Short history of Malaysia: Linking East and West (Crows Nest: Allen \& Unwin, 2003), 279-81.

${ }^{9}$ Ibid, 281.

10 John Falconer, A Vision of the Past: A History of Early Photography in Singapore and Malaya; The Photographs of G. R. Lambert \& Co., 1880-1910 (Singapore: Times Editions, 1987), 12.

${ }^{11}$ Falconer, A Vision of the Past, 9; Gilbert Gimon, “Jules Itier, Daguerreotypist," History of Photography 5.3 (1981): 225-44. Jules Itier jointed the French Customs Service in 1819. On 12 December 1843, as the chief of a French commercial mission to China, The East Indies and The Pacific, Itier left France to China, and on 3 July 1844 he arrived in Singapore.
} 
1800-c.1857) established the first daguerreotype studio in the land. ${ }^{12}$ From the 1850 s

onwards, photographers such as H. Husband, C. Duban, J. Newman, and Edward A. Edgerton successively set up studios, but the majority of these studios were short-lived. ${ }^{13}$ The Malayan mainland also attracted travelling photographers such as Henry Schuren ${ }^{14}$ and John Thomson, ${ }^{15}$ who used Singapore as a base to visit other countries and the outlying locations in the Malayan mainland.

In the 1860s, long-lasting photographic firms such as Sachtler \& Co. ${ }^{16}$ and G. R. Lambert \& Co. ${ }^{17}$ were established, and of these, G. R. Lambert \& Co. became a significant studio with regard to the history of photography in Malaysia. The studio provided the largest illustrated documentation of the Malayan mainland during the latter half of the nineteenth century. ${ }^{18}$ From 1867 to 1918 , it is not far-fetched to say that the history of photography in Malaysia and Singapore is the history of G. R. Lambert \& Co. ${ }^{19}$

\section{History of Photography in Ceylon (1850-1900) ${ }^{20}$}

It is believed that by as early as 1844, the first daguerreotype studios were operating in the city of Colombo and Kandy; however, the high level of heat and humidity allowed only a

\footnotetext{
12 Falconer, A Vision of the Past, 11; John Hannavy, ed., Encyclopedia of Nineteenth-Century Photography (New York: Taylor \& Francis Group, 2008), 1314. Gaston Dutronquoy arrived in Singapore in 1839 advertising himself as a portrait painter. Dutronquoy was actually a prominent hotelier. To an extent, his photographic activities were on an amateur basis.

13 Falconer, A Vision of the Past, 12-14, 17-18. Among these photographers, Edward A. Edgerton was the photographer who introduced the wet collodion process to Malaya.

14 Ibid, 25.

15 Ibid, 19-21; Stephen White and Robert A. Sobieszek, John Thomson: A Window to the Orient (New York: Thames and Hudson, 1985); Richard Ovenden, John Thomson (1837-1921) Photographer (Edinburgh: National Library of Scotland, 1997). John Thomson was the only identified photographer for this scrapbook; therefore, more discussion about Thomson's Far East trips and works is presented below.

${ }^{16}$ Falconer, A Vision of the Past, 21-25; Khoo Salma Nasution, More than Merchants: A History of the German-Speaking Community in Penang, 1800s-1940s (Penang: Areca Books, 2006), 34. Sachtler \& Co. was established by German photographer E. Hermann Sachtler in 1865, and ran until 1874.

17 Falconer, A Vision of the Past, 27-38. G. R. Lambert \& Co. was established by G. R. Lambert in 1867, and ran until 1918. It was the longest surviving photographic firm in nineteenth-century Malaya.

18 Ibid, 27-38.

19 Ibid.

20 Different from the history of other countries discussed in this thesis, the history of photography in nineteenth-century Ceylon (Sri Lanka) remains a neglected area of research.
} 
small number of this country's earliest daguerreotypes to survive. ${ }^{21}$ Although facing the harsh tropical climate, professional commercial photographers, as far back as the late 1840s and 1850s, established their studios throughout the island. ${ }^{22}$ Among them, J. Barrow, Juan de Silva, and John W. Vanderstraaten Jr. in Colombo along with A. W. Andree in Galle and Henry Marin in Jaffna, were important, better-known early figures. ${ }^{23}$ The photographic firm W. L. H. Skeen \& Co. (1860-c.1920) also played a significant role in terms of the history of photography in Ceylon. ${ }^{24}$ Similar to Malaysia, the exoticism of Ceylon attracted a number of Western photographers such as Frederick Fiebig (fl. 1840s), Samuel Bourne (1834-1912), and John Thomson. ${ }^{25}$ The pioneer fine art photographer Julia Margaret Cameron (1815-1879) also began to photograph in Ceylon beginning in $1875 .^{26}$

In addition to the professionals, amateur photographers also appeared among the Ceylonese middle class by the end of the nineteenth century. ${ }^{27}$ These amateurs not only actively adopted the evolving techniques, but also formed clubs and societies and even organized private and public exhibitions. ${ }^{28}$

\section{History of Photography in India (1840-1911)}

Early photographic activity in the Indian Peninsula met some challenges which seemed “insurmountable": dampness, high temperatures, and inadequate supplies of water. ${ }^{29}$ In spite of these conditions, photography first appeared in the Indian Peninsula in the 1840 s. ${ }^{30}$ By

\footnotetext{
${ }^{21}$ Ismeth Raheem and Percy Colin Thomè, Images of British Ceylon: Nineteenth Century Photography of Sri Lanka (Singapore: Times Editions, 2000), 10-11.

22 Ibid, 11.

23 Ibid; Hannavy, Encyclopedia, 256. The earliest surviving photographs of Sri Lanka are attributed to Frederick Fiebig, a German lithographer and calotypist.

${ }^{24}$ Raheem, Images of British Ceylon, 58-65.

25 Ibid, 19-22.

26 Ibid, 33-37; Hannavy, Encyclopedia, 529.

27 Raheem, Images of British Ceylon, 12.

${ }^{28}$ Ibid.

${ }^{29}$ Clark Worswick and Ainslie Embree, The Last Empire: Photography in British India, 1855-1911 (Millerton, NY: Aperture, 1976), 4.

30 Ibid, 1.
} 
1890, photography had become a well-developed activity with regard to both professional and amateur photography carried out by both Western and Indian photographers. ${ }^{31}$

In 1849, F. Schranzhofer opened the first documented studio in India. ${ }^{32}$ In 1854-55, the first Indian photographic society, the Photographic Society of Bombay, was founded. ${ }^{33}$ In the 1870s and 1880s, photographic firms such as Bourne \& Shepherd and Johnston \& Hoffman could provide "superb” prints to the market. ${ }^{34}$

In terms of the development of photography in India, the British East India Company played a significant role. In 1855, the Company began replacing draftsmen with photographers. $^{35}$ These photographers progressively developed an Indian style of documentary and survey photography. ${ }^{36}$ Western photographers Felice Beato (1832-1909) ${ }^{37}$ and John Burke (c.1843-1900) ${ }^{38}$ also left important illustrated records of India. Among Indian photographers, Lala Deen Dayal (1844-1910), who opened the largest studio in Bombay and the first specialized studio for female photography in Secunderabad, was believed to be the first significant professional native Indian photographer. ${ }^{39}$

\section{History of Photography in China (1842-1900)}

Against the background of the First Opium War (1840-42), Western photographers visited China for the first time, accompanying Western military personnel, missionaries, and

\footnotetext{
31 Stuart Cary Welch, ed., India: Art and Culture, 1300-1900 (New York: Metropolitan Museum of Art, Holt, Rinehart and Winston, 1985), 445.

32 Welch, India: Art and Culture, 445; Worswick, The Last Empire, 3-4; Anne Lacoste, ed., Felice Beato: A Photographer on the Eastern Road (Los Angeles: The J. Paul Getty Museum: 2010), 192. F. Schranzhofer established a calotype studio in Calcutta in 1849.

${ }^{33}$ Worswick, The Last Empire, 4; Welch, India: Art and Culture; Lacoste, Felice Beato. By 1855, the Photographic Society of Bombay had more than 250 members. In 1856-57, produced by William Johnson and William Henderson, the Society published their first album, the Indian Amateur's Photographic Album.

${ }^{34}$ Worswick, The Last Empire, 4; Welch, India: Art and Culture, 445-6.

35 Worswick, The Last Empire, 4.

${ }^{36}$ Ibid, 5.

37 Ibid, 8; Lacoste, Felice Beato.

38 Worswick, The Last Empire, 8.

39 Welch, India: Art and Culture, 445-447. Lala Deen Dayal was assigned as a court photographer in 1884. "He was also the only photographer in India entitled to follow his name with 'By appointment, Photographer to Her Imperial Majesty, Queen Victoria.”
} 
consular officials. ${ }^{40}$ The earliest recorded photographic activity in China by Western photographers was in July $1842,{ }^{41}$ only three years after the invention of the medium. Dr. Richard Woosnam (1815-1888) and Major George Alexander Malcolm (1810-1888) made daguerreotypes at Yangtze (Yangzi) River during the final stages of the First Opium War. ${ }^{42}$ In 1842, the Treaty of Nanking (Nanjing) was signed between the defeated Qing government and Britain. As a result, five trade ports ${ }^{43}$ were opened to foreigners, and Hong Kong became a British colony. This provided the first opportunity for Western photographers such as Jules Itier ${ }^{44}$ and George R. West (c.1825-1859) ${ }^{45}$ to visit China.

The Second Opium War (1856-1860) once again encouraged both amateur and commercial Western photographers to come to China. Photographers such as Paul-Emile Marie Camille Berranger (1815-1896), ${ }^{46}$ Colonel Charles Louis Desiré Dupin (1814-1868), ${ }^{47}$ Lieutenant John Ashton Papillon (1838-1891), ${ }^{48}$ and Felice Beato, ${ }^{49}$ among others, accompanied the military forces that visited the mainland. The Treaties of Tientsin (Tianjin), signed in 1858, allowed Britain, France, Russia, and the United States to establish legations in Peking (Beijing). Diplomats such as Robert Morrison (1825-1911) and William Nassau Jocelyn (1832-1892) could thus come to Peking to photograph and record significant

\footnotetext{
40 Terry Bennett, History of Photography in China, 1842-1860 (London: Bernard Quaritch Ltd., 2009), 1-2.

41 Ibid.

42 Ibid. Woosnam and Malcolm were the assistants to the British envoy Sir Henry Pottinger (1789-1856).

43 These five ports were Canton (Guangzhou), Amoy (Xiamen), Foochowfoo (Fuzhou), Ningpo (Ningbo), and Shanghai.

44 Bennett, 1842-1860, 3-6; Gimon, “Jules Itier, Daguerreotypist.” At the time, Itier took a good number of daguerreotypes, among which over forty have survived as the first photographs of China.

45 Bennett, 1842-1860, 9-15; Samuel C. Busey, "Early History of Daguerreotype in the City of Washington,” Records of the Columbia Historical Society (Washington, D. C.) 3 (1900): 81-95, accessed May 13, 2014, http://www.daguerreotypearchive.org/texts/P9000001_BUSEY_WASHINGTON_1900.pdf. George R. West was a commercial daguerreotype photographer who joined the American diplomatic mission as an official artist. He visited China in 1844 and set up one of the first commercial photographic studios in Hong Kong in 1845.

46 Bennett, 1842-1860, 90-93. Berranger was a member of the French naval and military forces during the Second Opium War. He was famous for the earliest surviving paper photographs of Canton.

47 Ibid, 96-102; David Harris, Of Battle and Beauty: Felice Beato's Photographs of China (Santa Barbara, CA: Santa Barbara Museum of Art, 1999), 40. Colonel Dupin was also a member of the French naval and military forces. According to Bennett, the only photographs of the final stages of the Second Opium War are attributed to Colonel Dupin.

48 Bennett, 1842-1860, 110-115; John Falconer, “John Ashton Papillon: An Amateur Photographer in China 1858-60,” The Photographic Collector 3. 3 (1982): 346-62. Papillon was one of the military photographers in Canton with the Royal Engineers during the Second Opium War.

49 Bennett, 1842-1860, 141-162; Harris, Of Battle and Beauty.
} 
events. $^{50}$ After the Second Opium War, a limited number of legation staff, missionaries, and Imperial Maritime Customs Service officials were also allowed to reside in Peking. The medical missionary Dr. John Dudgeon (1837-1901) ${ }^{51}$ and Customs employee Thomson Child (1841-1898) ${ }^{52}$ were among the significant amateur and part-time commercial photographers who documented nineteenth-century Peking.

The Treaties of Tientsin also stipulated the opening of four or more trade ports. ${ }^{53}$ This encouraged commercial photographers such as Charles Leander Weed (1824-1903) ${ }^{54}$ and Milton M. Miller (1830-1899) ${ }^{55}$ to visit China in search of commercial opportunities, and the successes of these two pioneering figures attracted a good number of photographers who set up studios in the treaty ports. ${ }^{56}$ William Pryor Floyd (1834-c.1900), who set up a studio in Hong Kong in 1866, ${ }^{57}$ and John Thomson, who set up a studio in Hong Kong in 1868, ${ }^{58}$ were two of the most noted later commercial photographers.

Native Chinese photographers made their appearance in the early 1840s. The autodidact Zou Boqi (1819-1869) is believed to be one of the first Chinese photographers to

\footnotetext{
50 Bennett, 1842-1860, 123-139; Laurence Oliphant, Narrative of the Earl of Elgin's Mission to China and Japan in the Years 1857, '58, '59 (Edinburgh: William Blackwood \& Sons, 1859), 16-17, accessed May 13, 2014, https://archive.org/details/narrativeearlel03olipgoog. Morrison and Jocelyn were two attachés to Lord Elgin's 1857-1859 embassy to China. They were successively assigned to photograph main events.

51 Terry Bennett, History of Photography in China, Western Photographers 1861-1879 (London: Bernard Quaritch Ltd., 2010), 31, 37-55; Nick Pearce, Photographs of Peking, China 1861-1908 (NY: The Edwin Mellen Press, 2005), 34-5; Nick Pearce, “A life in Peking: The Peabody Albums,” History of Photography 31.3 (2007): 276-87.

52 Bennett, 1861-1879, 56-78; Colin Osman, “In Search of Thomson Child,” British Journal of Photography 6729 (1989): 16 - 17, 6730 (1989): 18-19, 6732 (1989): 14-15; Colin Osman, “Thomson Child (1841-1898) Photographer of Peking,” The Photo Historian 84 (1989): 3-5.

53 These four ports were Newchwang (Yingkou), Tamsui (Danshui), Hankow (Hankou), and Nanching (Nanjing).

54 Bennett, 1842-1860, 163-169; Clark Worswick, ed., Sheying: Shades of China, 1850-1900 ([Madrid]: Turner; New York, NY: D.A.P., 2008), 12. According to Worswick, Weed arrived in China in 1860.

55 Bennett, 1842-1860, 169-193; Worswick, Sheying, 12; Wu Hung, "Inventing a 'Chinese' Portrait Style in Early Photography: The case of Milton Miller,” in Brush and Shutter: Early Photography in China, ed. Jeffrey W. Cody and Frances Terpak (Los Angeles: Getty Research Institute, 2011), 69-90. Miller arrived in China in 1861. He was not only the best portrait photographer in nineteenth-century China, but also one of the Western photographers who established and developed his own Chinese portrait style.

56 Bennett, 1842-1860, x.

57 Bennett, 1861-1879, 7-18. According to Bennett, Floyd's studio was one of the most successful studios in nineteenth-century Asia. A detailed description of Floyd's career is found below.

58 Ibid, 214-256.
} 
learn photography without the help of foreign photographers. ${ }^{59}$ Among the most notable commercial Chinese photographers in nineteenth-century China, influenced or taught by foreign photographers, were: Afong (Lai Fong) (c.1839-1890), whose studio in Hong Kong ran from 1870 to at least 1887; $;^{60}$ Pun Lun (Bin Lun), whose studio in Hong Kong ran from 1864 to at least $1889 ;^{61}$ and See Tay (Liang Shitai), who successively set up studios in Hong Kong, Shanghai, and Tientsin from the 1870 s to the 1880 s. $^{62}$ The late nineteenth century saw the designation of the first official Chinese court photographer: Shilling (Yu Xunling) (ca. 1880-1943), who became famous as the only royal photographer assigned to Empress Dowager Cixi. $^{63}$

\section{Photographer John Thomson and His Ten-Year Far East Sojourn}

Since there are photographs in the scrapbook that can be attributed to John Thomson, this photographer and his ten-year Far East trip deserve an entire section. As mentioned earlier, Edinburgh-born photographer John Thomson was one of the first photographers who traveled to the Far East, and, along with Milton M. Miller, he was also one of the pre-eminent

\footnotetext{
59 Bennett, 1842-1860, 6-8; Terry Bennett, History of Photography in China, Chinese Photographers 1844-1879 (London: Bernard Quaritch Ltd., 2013), 5-8; Edwin K. Lai, “The History of the Camera Obscura and Early Photography in China,” in Brush and Shutter, 19-20; Oliver Moore, “Zou Boqi on Vision and Photography in Nineteenth-Century China,” in The Human Tradition in Modern China, ed. Kenneth J. Hammond and Kristin Stapleton (Lanhan, MD: Rowman \& Littlefield, 2008), 40-42.

60 Bennett, 1844-1879, 66-98; John Thomson, The Straits of Malacca, Indo-China, and China; or, Ten Years' Travels, Adventures, and Residence Abroad (London: Sampson Low, Marston, Low, \& Searle, 1875), 188-89, accessed April 4, 2014, https://archive.org/details/straitsofmalacca00thomuoft; John Thomson, "Hong Kong Photographers,” British Journal of Photography 19 (1872): 569, 591-2. Afong probably was the Chinese photographer who was the most familiar to Westerners. John Thomson was one of the Western photographers influenced by him. After Thomson returned to England, Thomson continued to recommend Afong's work to the British.

61 Bennett, 1844-1879, 100-106; Lai, “The History of the Camera Obscura,” 26-27; Jeffrey W. Cody and Frances Terpak, “Through A Foreign Glass: The Art and Science of Photography in Late Qing China,” in Brush and Shutter, 37.

62 Bennett, 1844-1879, 106-107; Lai, “The History of the Camera Obscura,” 27-28; Edwin K. Lai, “Liang Shitai, Chinese Court Photographer from Hong Kong,” in Responding to Art: From, Content, and Context, ed. Robert Bersson (New York: McGraw-Hill, 2003), 160-1. See Tay was the photographer who took remarkable photographs of Prince Chun Xian (1841-91), father of the Emperor Guangxu, and his gardens.

63 Jing Lin, The Photographs of Cixi in the Collection of the Palace Museum, Beijing: Forbidden City Publishing House, 2002; Clark Worswick, "Photography in Imperial China,” in Imperial China: Photographs 1850-1912, ed. Clark Worswick et al. (New York: Pennwick, 1978), 144-5.
} 
European photographers in nineteenth-century China. ${ }^{64}$

In 1862, Thomson left for Singapore and embarked on a ten-year sojourn in Asia. ${ }^{65}$ Upon arrival, he established a studio together with his brother, William, who had settled in Singapore in August 1859 to set up a watch-making business. ${ }^{66}$ Using Singapore as a base, Thomson made his first photographic journey to Penang and Wellesley Province, Malaysia, in 1862. ${ }^{67}$ From 1865 to 1866, Thomson visited Siam, Laos (controlled by Siam and Vietnam), and Cambodia. ${ }^{68}$ He returned to England in 1866, but travelled back to Asia in July 1867. ${ }^{69}$ After moving his studio from Singapore to Hong Kong in 1868, he spent the next five years documenting China and the Chinese people, their architecture, landscape, and culture. $^{70}$ Thomson's travels within China were extensive, from the southern trading ports of Hong Kong and Canton to Peking in the north, and from the island of Taiwan in the Southeast to the interior of China. ${ }^{71}$

What distinguishes Thomson's Far East trips from those of other photographers was his network of contacts, which allowed him access to sites and people that few others achieved. $^{72}$ He photographed the King of Siam in 1865, and, using the passport (letter) issued by the King himself, he visited Laos and Cambodia in 1866 and photographed the King of Cambodia. ${ }^{73}$ He was, we may suppose, the first person who photographed these two

\footnotetext{
64 Worswick, Sheying, 12.

65 White, John Thomson, 195; Ovenden, John Thomson, 6.

66 Nick Pearce , “John Thomson’s China: 1868-1872.” In China Through the Lens of John Thomson 1868 -1872, Beijing World Art Museum (Bangkok: River Books Press: 2010), 6-7.

67 White, John Thomson, 9-10, 195; Ovenden, John Thomson, 6-8; John Thomson, The Straits of Malacca, Indo-China, and China.

68 White, John Thomson, 11-15, 195; Ovenden, John Thomson, 8-10; Thomson, The Straits of Malacca, Indo-China, and China; “John Thomson's China: A Scot who Travelled Throughout the Far East, Photographing Everyday Life,” accessed May 25, 2014,

http://www.wellcomecollection.org/explore/time--place/topics/john-thomsons-china/john-thomsons-china.aspx.

69 White, John Thomson, 15, 195; Ovenden, John Thomson, 11-13.

70 White, John Thomson, 195; Ovenden, John Thomson, 13-17.

${ }^{71}$ White, John Thomson, 17-29, 195; Ovenden, John Thomson, 17-20; “The Photographs of John Thomson,” accessed in November 11, 2013, http://digital.nls.uk/thomson/index.html.

72 Pearce, “John Thomson's China: 1868-1872,” 6-7.

73 White, John Thomson, 11-15, 195; Ovenden, John Thomson, 8-10; Thomson, The Straits of Malacca, Indo-China, and China.
} 
kings and the first photographer who visited Cambodia, ${ }^{74}$ which is now one of the most renowned countries in terms of ancient architecture.

Another characteristic that reveals how Thomson was ahead of his time is that he is considered one of the first photojournalists. Indeed, he had a keen "journalistic interest in documenting his travels,"75 and his journeys were recorded in his illustrated books and articles. He was one of the first professional photographers "whose careers do not depend purely on the number of prints sold, ... but on the publication of their photographic images through conventional print media,"76 and these books and articles now are "one of the richest sources of Asian photography of the period."77

\footnotetext{
74 Ovenden, John Thomson, 10.

75 Worswick, Sheying, 24.

76 Ovenden, John Thomson, xi.

77 Worswick, Sheying, 24.
} 


\title{
Describing the Scrapbook
}

\section{Physical Dimensions of the Scrapbook and the Print Process}

The portrait format scrapbook measures 35 x 25 x $5.5 \mathrm{~cm}$. It has a dark blue cloth cover and a black leather replacement binding. The pages were initially sewn together, but are now disassembled. In total, there are 88 leaves in the scrapbook. The numbering system assigned by the archivist to this scrapbook is a standard pagination with odd numbers as the rectos and the even numbers as the versos. The majority of the photographs are mounted on the recto leaves, with occasionally on the versos.

There is a small black leather label, stamped in gold with the word "SCRAPBOOK," attached to the outside front cover of the book. Yellow and green marbled paper has been used for both front and back endpapers. On the top left of the front pastedown there is an applied binder's label indicating that the scrapbook was bound in Hong Kong; see Illustration 1 below.

Illustration 1. Binder Label

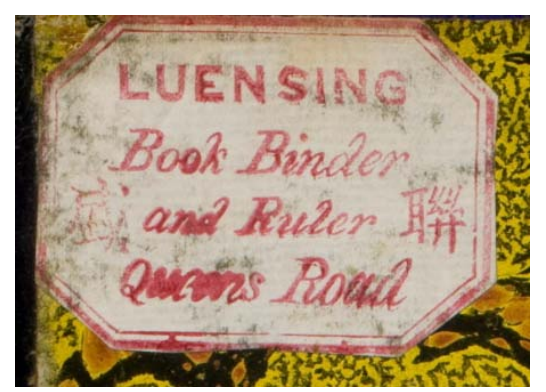

\author{
“LUENSING \\ BOOK Binder \\ And Ruler 聯 \\ Queens Road”
}

This scrapbook contains 120 photographs, three photographic copies (photographs of a photograph and/or paper materials), and one newspaper clipping. The photographs are in various sizes: nineteen are approximately 5 x 9 cm; eighty-two are approximately 32 x 24 cm; and twenty-two are approximately $10 \times 13 \mathrm{~cm}$. There are two photographs that are slightly larger than the page and were folded down in order to fit the size of the book: 0053 measures 26.6 x $30.5 \mathrm{~cm}$ and 0054 measures 25.6 x $30.5 \mathrm{~cm}$. 
The photographs in this album are albumen prints made from wet collodion negatives. Even though the pages of the scrapbook are themselves fragile, the overall condition of the albumen prints is fairly good. ${ }^{78}$

\section{Inscriptions}

Almost all the photographic prints in the scrapbook have handwritten texts associated with them. Upon further examination, I found that there are handwritten texts on the backs of some of the prints as well. By photographing the scrapbook pages on a light box, the backs of the prints are visible. In comparing the handwriting, it can be argued that of all the captions in the scrapbook, on both the recto and verso of the prints, were written by the same person. ${ }^{79}$

Since this scrapbook was originally attributed to John Thomson, comparing the handwriting in the scrapbook with Thomson's handwriting was imperative. William Schupbach, a librarian with the Iconographic Collections at Wellcome Library, London, kindly provided samples of Thomson's handwriting for this purpose. ${ }^{80}$ In comparing some specific letters and words, the handwriting in the scrapbook shows similar characteristics to that of Thomson. ${ }^{81}$ However, Richard Ovenden, who holds samples of Thomson's handwriting provided by the photographer's successors, rejects this hypothesis maintaining that "Victorian British hands are quite hard to distinguish." 82 Therefore, unless graphology experts appraise the handwriting, it is impossible for museum and photography specialists to

\footnotetext{
78 Mark Osterman, Photographic Process Historian, George Eastman House, interview with author, March 24, 2014. None of the prints shows surface cracking, a condition that is frequently seen on albumen prints in nineteenth-century travel albums, caused by acquiring rolled up albumen prints in one country, which were then re-opened in another country.

79 This point of view is also shared by Joe R. Struble, Collections Manager of the Department of Photography, George Eastman House, interview with author, March 17, 2014. Struble suggests that these inscriptions were written in different time periods using different pens, and that the writing on the front of the photograph points to a more cautious attitude than writing on the back. Even though some handwriting on the backs of the photographs cannot be confirmed, the majority of the handwriting in this scrapbook is likely from one person. 80 Thomson donated almost all of his negatives to the Wellcome Library, London, before he died. Today, the Wellcome Library holds the largest Thomson collection in the world.

81 Some examples are presented in the Appendix 2.

82 Ovenden, e-mail message.
} 
provide a conclusive or convincing attribution by analyzing the handwriting alone.

\section{Image Grouping}

The majority of the photographs in the scrapbook are of landscapes and street scenes. According to the inscriptions, they were taken in the following locations: Penang and Wellesley Province in Malaysia; Galle in Ceylon; Calcutta, Lucknow, and Ramkistopore in India; Singapore; and Amoy, Canton, Macao, and Hong Kong in China. The inscriptions also indicate that the photographs were taken as early as 1864 . Based on the locations, the images can be divided into four groups: Malaysia and Ceylon; India; Singapore; and China. However, there are several exceptions.

The first exception occurs on the verso of the front endpaper, which is deemed "page 0" by the cataloguer. Here there are five portraits, comprising two individual studio portraits and three group portraits.

Group 1 (image numbers are 0001 to 0028 ) is found in pages 1-19, ending with the first of two images on page 19. There are twenty-two photographs in total. On pages 1 and 3, there is one mounted photograph of Malaysia per page. On page 4, there are nine carte-de-visite sized photographs of Ceylon (this is the second exception for the grouping). On pages 5-19, there are eleven photographs of Malaysia again. On pages 5, 7, and 13, there is one mounted photograph per page; and on pages $9,11,15$, and 17 , there are two photographs per page. On page 9, the inscription for photograph 0020 is "Siamese Temple." The architecture recalls a Siamese Buddhist temple with its steeple and stacked roof. However, according to the Special Collections at the University of Massachusetts, Amherst, the caption for the same image is "Temple, Penang.",33 Therefore, whether "Siamese Temple” means a temple at Siam or a Siamese temple at Penang is undetermined.

\footnotetext{
83 UMass Amherst Libraries, Special Collections \& University Archives, "John Thomson Photograph Collection,” accessed April 4, 2014, http://www.library.umass.edu/spcoll/ead/muph002.html\#.
} 
Group 2 extends from the second photograph on page 19 to page 65 (image numbers are 0029-0055); there are twenty-six photographs of India. On pages 19-25, there are two mounted photographs per recto page; and on pages 27-65, there is one photograph per recto page.

Group 3 extends from page 66 to page 72 (image numbers are 0056 to 0063); there are eight photographs of Singapore. On pages 66 and 68, there are two mounted photographs per page; and on pages $67,69,71$, and 72 , there is one photograph per page.

Group 4 extends from page 73 to page 177 (image numbers are 0064 to 0123); there are sixty-two images in total, among which there are 3 photographic copies and fifty-nine photographs of China. There are two photographic copies (two photographs of hand-made montages) on page 104 and one photographic copy on page 130. There is a newspaper clipping on page 100. In this group, each recto page contains one photograph; and on the verso pages $74,76,102,106$, and 130 , there is one mounted photograph per page.

\section{Matching John Thomson's Photographs}

The scrapbook includes twelve images signed “J. Thomson” or “Thomson.” A stylus would have been used to scratch the signature into the surface of the collodion coating. Since the scrapbook was originally attributed to John Thomson, the starting point of this project is matching the images in the scrapbook with confirmed Thomson works. The sources consulted include Thomson's travelogues and publications, institutional collections that include Thomson's prints and negatives, and scholarly works.

Upon comparison, there are thirty images that can be matched with confirmed Thomson works, of which six are signed. Besides these thirty images, there are three more images signed by Thomson but no matched images are found in the sources that were consulted. Therefore, there are thirty-three out of 123 images that can be attributed to John 
Thomson. ${ }^{84}$ Attributions for the remaining ninety images are impossible to make at this time.

In Group 1 (Malaysia and Ceylon), there are two images attributed to Thomson.

There is no image in Group 2 (India) corresponding to the matching results.

In Group 3 (Singapore), there is one image attributed to Thomson.

In Group 4 (China), there are thirty images attributed to Thomson. Also, all nine of the signed images belong to this group.

${ }^{84}$ A detailed matching result is presented in Appendix 3. 


\section{Debating Scholarly Arguments about Thomson}

After matching the images with scholarly sources, the focus shifts to the examination of the original attribution for this scrapbook and the soundness of the attribution.

First suggested by Stephen White, David Wooters has given one of the justifications, and also the most important reason, for attributing all of the work in this scrapbook to John Thomson: “The parallel between Thomson's life and this album's contents and sequence is very strong." 85 Wooters also states that

The first ten views in the album are of Penang, where Thomson first established himself in the Far East in 1862. The next 14 photographs are of the cyclone that hit Calcutta in October 1864. Thomson was in India at that time and photographed the aftermath of the cyclone. The next 12 photographs are also of India, but of other locations, predominantly Lucknow. Thomson remained in India until November, when he returned to Singapore, where he had moved in 1863 and which is pictured in the next 5 photographs of the album. ${ }^{86}$

Three considerations throw doubt on the statement in the Eastman House cataloguing records. Firstly, whether Thomson visited India in 1864 and photographed the 1864 Calcutta cyclone has not been established. In his 1985 book, White states: "In October 1864 Thomson set out by way of Ceylon for India. He was admitted to membership of the Bengal Photographic Society and photographed the devastation newly wrought in the area by a cyclone....”87 White also writes “Thomson gave a talk to the Bengal Photographic Society in 1864."

Richard Ovenden disputes this assertion in his 1997 book: "The suggestion that he [Thomson] visited India, probably based on the fact that he was a member of the Bengal

\footnotetext{
85 Eastman House's collection management system (object name John Thomson Scrapbook).

${ }^{86}$ Ibid.

87 White, John Thomson, 11.

${ }^{88}$ White, e-mail message, April 1, 2014.
} 
Photographic Society, is otherwise unsubstantiated." ${ }^{89}$ He adds: "The photograph of a destructive Indian cyclone in 1864, which has been attributed to Thomson by Stephen White, was no doubt taken by one of a number of other photographers known to have taken similar images." 90 Ovenden further states that Thomson "was proposed for membership of the Bengal Photographic Society at the meeting of 25 October 1864, and elected at the following meeting of 22 November 1864."91

In addition to Thomson being a member of the Society, another reason that White believes Thomson once visited India in 1864 is likely because the Society Journal (1864) includes Thomson’s article. ${ }^{92}$ However, including Thomson’s article does not mean that he attended the meeting; it is possible that he submitted his article, but did not necessarily physically attend the meeting. ${ }^{93}$

Also worth examining is Thomson's documentation of his travels. Clark Worswick states that “All his [Thomson's] journeys were recorded in [his] illustrated travel books."94 Thomson's books and articles do not contain any descriptions of India, but only brief descriptions of Indian businessmen’s experiences in Singapore and nearby countries. Had Thomson visited India, we would expect to find the same detailed descriptions of the country, its culture, customs, landscape, and local photographers that he vividly recorded in his other books.

The second problem with White's and Wooters' attribution is that the scrapbook's contents and sequence do not parallel Thomson's life and travels as White and Wooters assert. As mentioned earlier, the photographs in this scrapbook are roughly in accordance with the

\footnotetext{
89 Ovenden, John Thomson, 8.

90 Ibid.

91 Ibid, 188.

92 Journal of the Bengal Photographic Society, 3 (1864), 18, 20, quoted in Ovenden, John Thomson, 188; White, interview with author, April 17, 2014.

93 David Harris, Professor and Director of the Film and Photography Preservation and Collections Management Program, Ryerson University, interview with author, April 23, 2014.

94 Worswick, Sheying, 24.
} 
sequence of Malaysia and Ceylon, India, Singapore, and China. Thomson's documented Far East journeys, however, are as follows: ${ }^{95}$

- 1862- Left England on April $29^{\text {th }}$ and settled in Singapore no later than June $12^{\text {th}}$; spent ten months in Penang and Wellesley Province, Malaysia.

- 1863- Remained in Malaysia earlier this year until he returned to Singapore.

- $1864^{96}$

- 1865- Arrived Siam no later than September $28^{\text {th }}$ and spent six months in Siam when he first time photographed the King of Siam, Mongkut (1804-1868).

- 1866 - Left Siam on January $27^{\text {th }}$ for Cambodia and Laos and arrived Cambodia on March $27^{\text {th }}$, where he photographed the King of Cambodia, Norodom (1834-1904) and Angkor Wat; returned to Bangkok when he photographed the King of Siam second time and then returned to Singapore at where he left for Edinburgh in May or June.

- 1867- Returned to the Far East later this year to Singapore and visited Vietnam the same year.

- 1868- Remained in Vietnam earlier this year; settled in Hong Kong no later than March $11^{\text {th }}$ and began working on photographing China and the Chinese until the autumn of 1872, when he returned permanently to England

There are no photographs of Siam, Laos, Cambodia, and Vietnam in this scrapbook. This diminishes the claim that the scrapbook mirrored Thomson's travels in both subject matter

\footnotetext{
95 White, John Thomson, 195; Ovenden, John Thomson, 6-17. Aside from the countries listed here, Thomson also visited Ceylon (Sri Lanka) after he settled in Singapore in 1862. He recorded this trip in The Straits of Malacca, Indo-China, and China: “...The project I was unable to carry out, so that my experiences in Ceylon are confined to the narrow limits of Galle harbour and to the adjacent hills such indeed as fall to the lot of all who travel by the steamers of the Peninsular and Oriental line.” The exact year when he visited Ceylon is unconfirmed.

96 Thomson's travels in 1864 are disputed in the sources.
} 
and sequencing.

The experiences and photographs of Siam and Cambodia were extremely important to Thomson. Not only did he make successful and impressive portraits of the kings of these two countries, but he was also the first Western photographer to photograph Angkor Wat. He also believed that this trip would "establish his reputation as a serious traveler, photographer, and writer" in the circle he respected and admired. ${ }^{97}$ It was this trip that ensured his membership in the Ethnological Society of London (May 1866) and his rise to being a Fellow of the Royal Geographical Society in November of the same year. ${ }^{98}$ This same journey helped him successfully establish important contacts in both Edinburgh and Glasgow in the Edinburgh Photographic Society and Glasgow Photographic Association, and gave him the opportunity to give private and public lectures on the subject of his travels. ${ }^{99}$ The journey through Siam and Cambodia resulted in his articles being published widely, and The Antiquities of Cambodia: A Series of Photographs Taken on the Spot became his first published book on the Far East. Were the “John Thomson Scrapbook,” compiled by John Thomson himself, and illustrated with his own work, it is very likely that Thomson would have included his photographs and experiences of these two countries. The fact of the matter is that he did not.

Another detail in the scrapbook that counters White's and Wooters' attribution is the inscription for 0101. Image 0101 is signed “J. Thomson” and its inscription reads “Junks H Kong.” Thomson's Illustrations of China and Its People Vol. II, Plate XIX is of the same image as 0101, and is titled “Old Junks.” In the book's text, it is noted that the image was taken at Canton River (Pearl River), which is far upstream from Hong Kong. Were the scrapbook assembled by Thomson, he would most likely not have misidentified where the image had been made.

\footnotetext{
97 Ovenden, John Thomson, 11.

98 Ibid.

99 White, John Thomson, 15; Ovenden, John Thomson, 11-12.
} 
Illustration 2. Image 0101

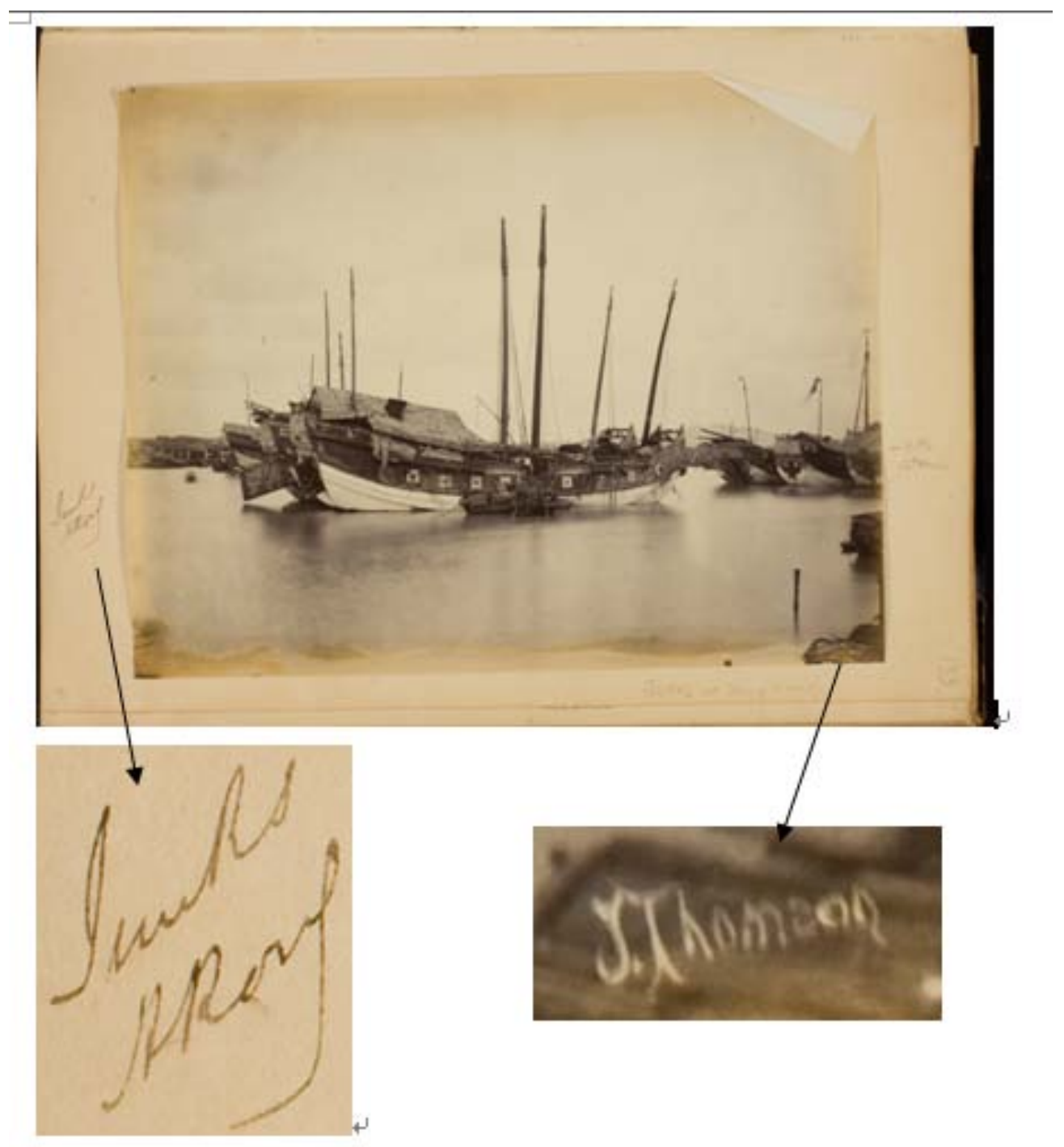




\section{Distinctive Features of This Scrapbook}

On one hand, based on the above inconsistencies, the original attribution for this scrapbook as John Thomson's personal scrapbook cannot be supported. On the other hand, this scrapbook also shows features that distinguish itself from a typical nineteenth-century souvenir travel album.

\section{Unusual Inscriptions}

One argument is that the scrapbook contains unusual inscriptions that typical nineteenth-century souvenir travel albums usually did not include. Since its emergence as a genre, the souvenir tourist photo album, which typically contains the local scenic images and/or portraits of the person (people) who visited these places, has acted both as a memento of a trip and a way to share the journey with others. Usually, the inscriptions in a souvenir travel album act as the only written clues that help the owner remember the details of the trip. For this reason, the maker or owner usually makes carefully and neatly presented, or at least legible and accurate, inscriptions. However, the inscriptions in this scrapbook tell a different story.

There are spelling mistakes in the inscriptions, as 0071 shows in the Illustration 3, which spells tea house as “tea hous.” There are a few inscriptions that are difficult to decipher, a good example being 0033. There are also some inscriptions in shorthand abbreviations: the maker or the owner of this scrapbook wrote “H. Kong” instead of Hong Kong, as seen in examples 0081, 0096, 0098 (front), 0100, 0101, 0104, 0110, 0119, 0121, 0122, and 0123. However, the maker or owner wrote “Hong Kong” for 0082, 0085, 0087, 0088, 0089, 0090, 0092, 0093, 0095, 0098 (back), and 0105, which indicates that “H. Kong” instead of Hong Kong was neither the popular form at that time, nor did it reflect a consistent style and use of abbreviations. 


\section{Illustration 3. Inscription 0071}

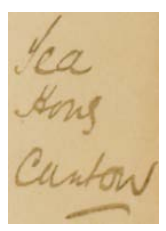

Illustration 4. Inscription 0033

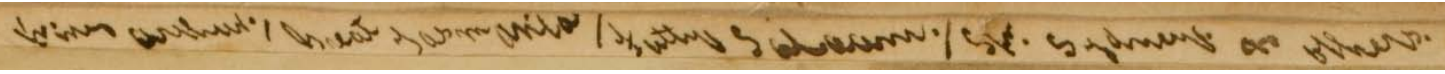

Illustration 5. Inscription 0081

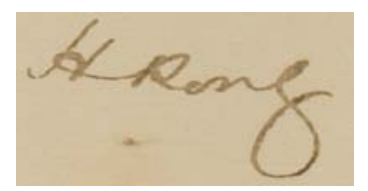

Illustration 6. Inscription 0082

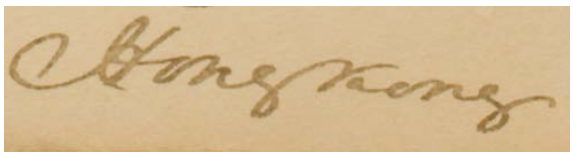

\section{Photographs were not Made for Commercial Purposes}

Under normal circumstances, photographs in a typical nineteenth-century souvenir travel album would have been made by the photographer(s) for commercial purposes and then acquired by the tourist who would later assemble an album from the souvenir market. In this scrapbook, however, there are evidences that demonstrate that some images were made by a professional or serious amateur photographer, or several such individuals, not for commercial purposes. This is the most notable feature that distinguishes this scrapbook from a typical tourist album.

\section{Photographic Copies}

As mentioned earlier, there are three photographic copies in this scrapbook: 0099 on page 130, whose inscription reads “Civis Romanus. (I am a Roman Citizen) 1869.,” and 0083 and 0084 on page 104, which are of particular interest.

Image 0083 measures 11.6 x $17.2 \mathrm{~cm}$ and 0084 measures 14.2 x $11.3 \mathrm{~cm}$. These two photographs were mounted close together. Unlike elsewhere in this scrapbook, there is no space between these two photographs. The inscription for 0083, "The Pantomime of the 
'Stamp Act' as performed at Government House," is written on the print instead of on the scrapbook’s page.

Similar to other photographs in this scrapbook, 0083 and 0084 are albumen prints from wet collodion negatives and both are photographs of hand-made montages. Image 0083 contains twelve different caricatures along with three fragments of newsprint. These figures are made up of cut-out heads, probably from carte-de-visite photos of politicians, and drawn-in bodies. Then all of it was re-photographed and the negative printed.

\section{Illustration 7. Images 0083-0084 on Page 104}

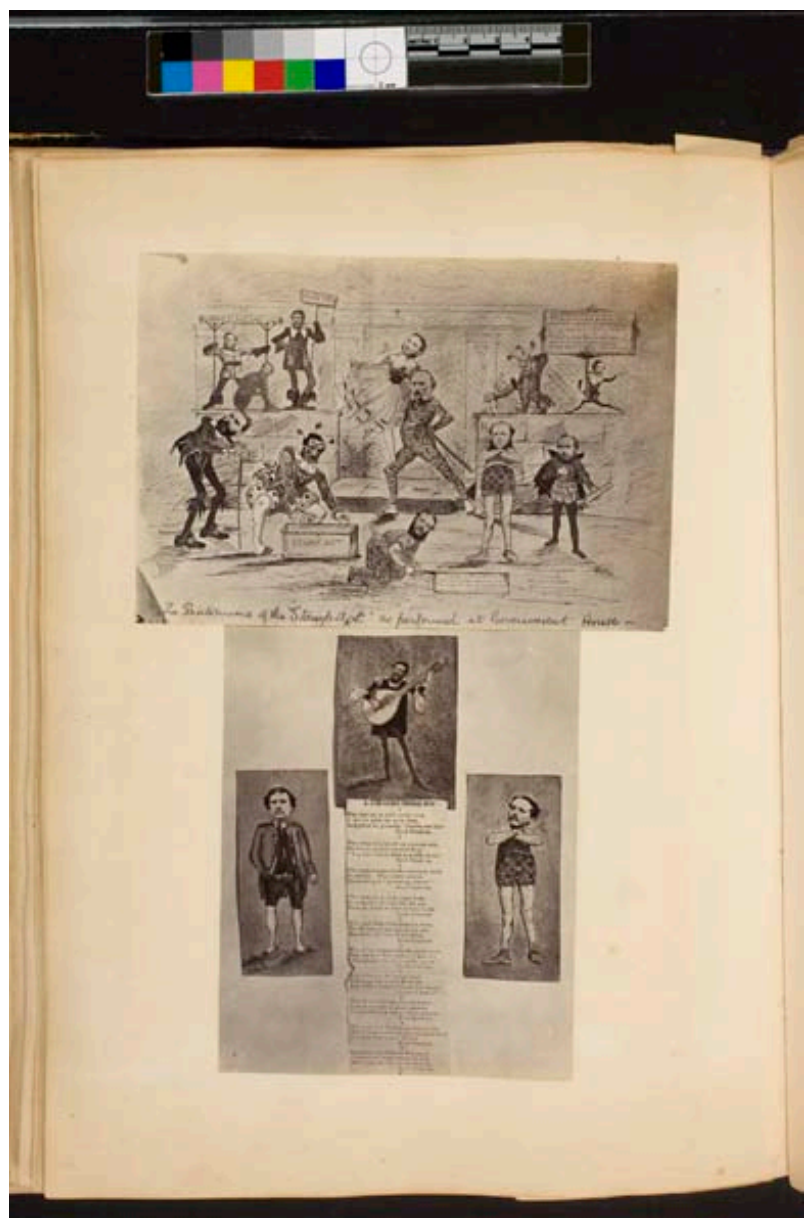

Illustration 8. Newspaper Clipping on Page 100

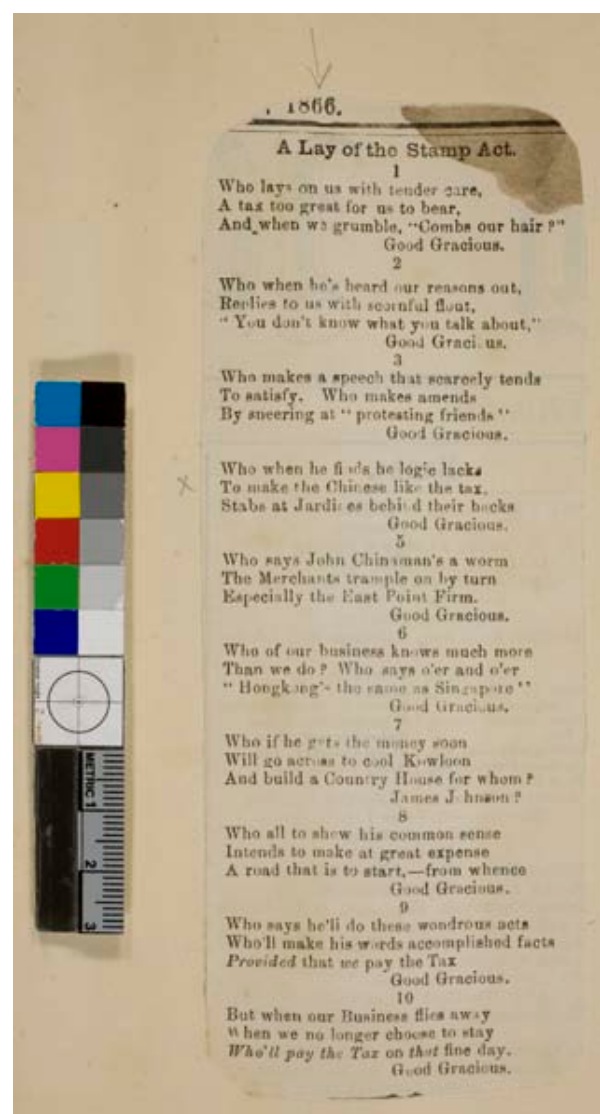

Image 0084 is composed of three caricatures, which are positioned at the left, top, and right of the print, and a newspaper clipping, which is positioned at the bottom. Each caricature portrays one individual. As is the case with 0083, the three figures have drawn-in bodies and cut-out heads. The newspaper clipping is a poem, which is titled "A Lay of the 
Stamp Act.” The text is identical to that of the photograph of the newspaper clipping on page 100. The three tiny pieces of clippings on 0083 are excerpts from the same poem. There are shadows at the edges of the caricatures and the clipping, which indicate that during the shooting, the compositions were not pasted down, but rather simply laid upon the background.

The inscription for 0083, “The Pantomime of the 'Stamp Act,” indicates that the characters in 0083 and 0084 were likely politicians related to the Stamp Act. Image 0083, 0084, and the clipping on page 100 belong to Group 4, China. The newspaper clipping on page 100 shows the newspaper was published in 1866, and the documents for the Hong Kong Stamp Act were passed by the Hong Kong Legislative Council on September $5^{\text {th }}, 1866 .{ }^{100}$ Therefore, it is likely that the aim for making this caricature was to satirize Hong Kong's "Stamp Act."

In all likelihood, the purpose of making and including 0083 and 0084 was for the personal recreation or amusement of the maker rather than commercial purposes.

\section{The Photographs of India}

Photographs in Group 2, which are photographs of India, also stand out when viewing the scrapbook.

\section{a. Black Borders}

The first distinction that arises relates to numbers 0044 to 0055 (inclusive); these twelve photographs show black borders, a photographic artifact which is related to glass plate negatives. Image 0109 from Group 4 also shows black borders.

The making of a wet collodion glass plate negative involved pouring a solution of collodion and potassium iodide over the glass plate. The process of hand-pouring the

\footnotetext{
100 “Documents Connected with the Hong Kong Stamp Act,” accessed May 27, 2014, https://openlibrary.org/works/OL5425400W/Documents_connected_with_the_Hong_Kong_Stamp_Act_passed _in_the_Legislative_Council_Sept._5th.
} 
chemicals frequently resulted in uneven edges of the collodion on the glass. The corner of the glass plate where the photographer's thumb held the plate during the pouring of the chemicals, and the edges of the plate that the chemicals did not reach, therefore remained chemical-free. These uncoated areas allowed light to pass through during the printing process, resulting in the black borders on the final positive print, such as the image 0109. Black borders on a photographic print could also occur during the printing process, when the collodion glass plate negative is smaller than the paper on which the image will be printed. Any area of the sensitized paper thus exposed directly to the sunlight during the printing process would turn black, such as in the image 0044, 0045, and 0055. In both these cases, however, these black borders were usually trimmed off for aesthetic reasons before the prints were sold to buyers.

These thirteen photographs were presented in the scrapbook untrimmed. Therefore, it is unlikely that these photographs were acquired from the tourist souvenir market.

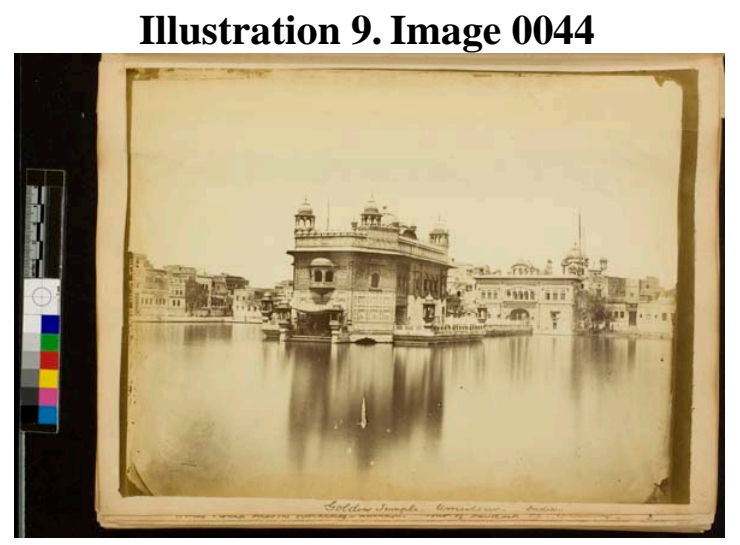

Illustration 11. Image 0055

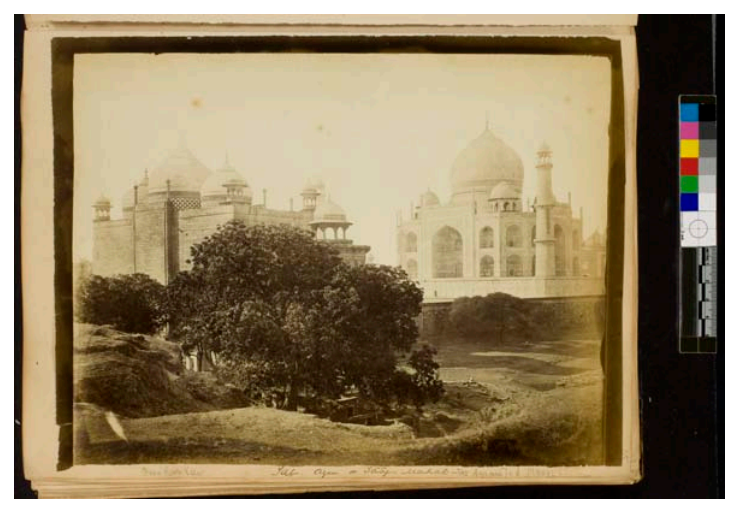

Illustration 10. Image 0045

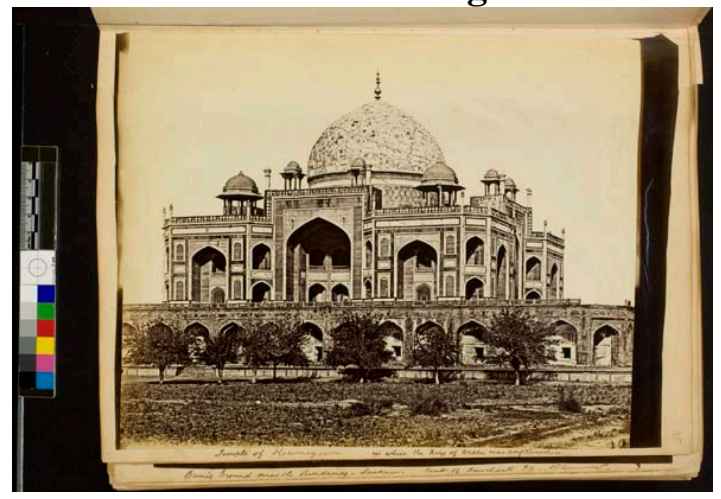

Illustration 12. Image 0109

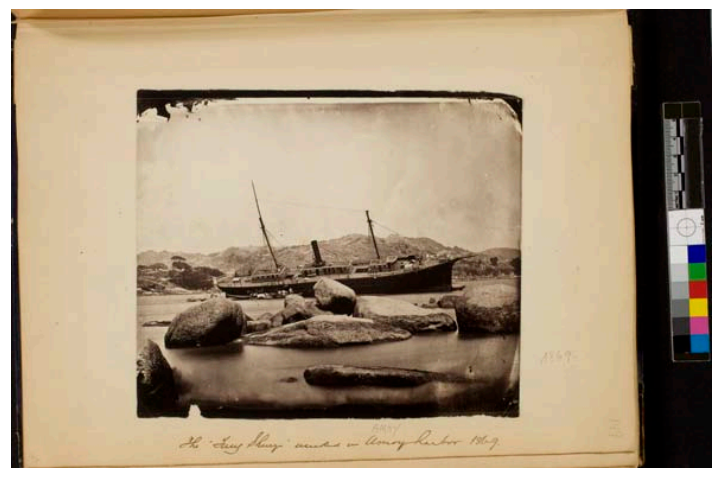


b. The Photographs of the 1864 Calcutta Cyclone

On October $5^{\text {th }}, 1864$, the city of Calcutta and its surrounding areas, West Bengal, India, were flooded and destroyed by a powerful cyclone. Approximately 60,000 people were killed by the cyclone, and thousands more died because of the diseases that followed. ${ }^{101}$ The anemometer in the city, which measures the force and speed of the wind, was blown away during the cyclone, and in the port of Calcutta out of 195 vessels, only twenty-three remained undamaged. ${ }^{102}$ In this scrapbook, fourteen consecutive photographs, 0029 to 0043 , record the aftermath of the cyclone.

Image 0029, the second image on page 19, was the first photograph of Group 2 and also the first photograph of the cyclone. On page 18, there is no photograph but an inscription, which reads “Cyclone 5th October 1864 Calcutta.” (Page 18 is also the only page in this scrapbook that has an inscription but no photograph.) These fourteen photographs were taken at various locations in Calcutta and surrounding regions, including Ramkistopore, Neemtollah Ghaut, Garden Reach, Jackson Ghaut, Armenian Ghaut, and Wood Street. They record the wreckages of the vessels at beaches, ghauts, and ports, the destruction of civilian houses and government buildings, and toppled trees and chimneys.

101 Gastrell, Report on the Calcutta Cyclone of the 5th October 1864, 126-129.

102 “Cyclones and Floods at Contai,” accessed February 10, 2014, http://www.contai.info/cyclone1.php. 


\section{Illustration 13. Page 18-19}

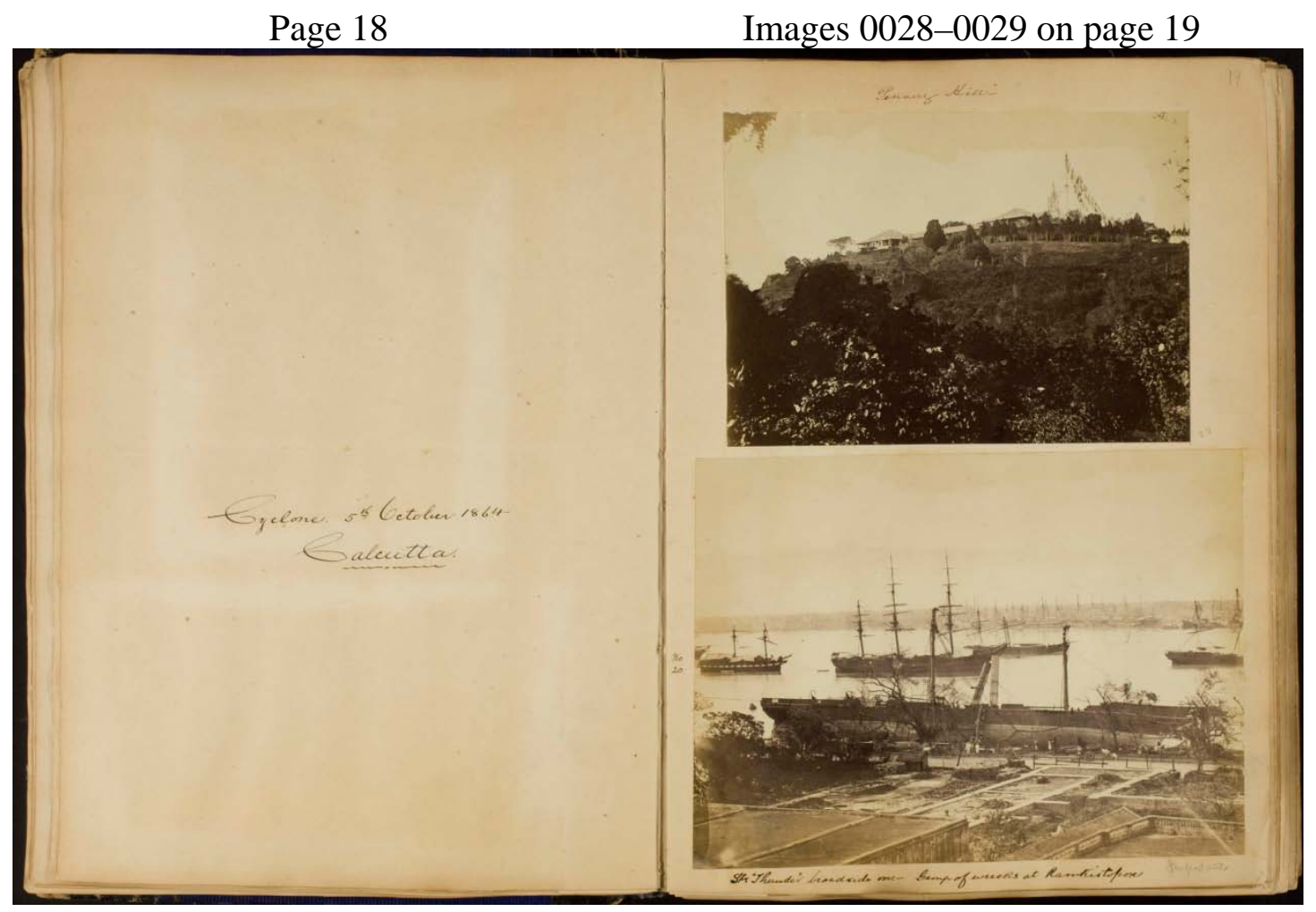

In general, natural disaster photographs, such as these fourteen photographs that record the cyclone, are found much less frequently in typical souvenir travel albums at the time than the souvenir images depicting local customs, natural scenery, representative and distinctive architecture, and ethnographical "types." Alternatively, natural disaster photographs were more likely reproduced as line engravings in newspapers or magazines, or tipped into limited edition illustrated books, or sold in pre-assembled albums, such as The Typhoon of September, 1874 sold by Afong's studio and the series of photographs published by Floyd, which both record the 1874 typhoon in Hong Kong and Macau. ${ }^{103}$

In conclusion, these twenty-six photographs of India, whether the 1864 cyclone photographs (0029 to 0043) or the photographs with their black borders untrimmed (0044 to 0055), distinguish this scrapbook from a typical nineteenth-century souvenir travel album.

103 Bennett, 1861-1879, 71. 


\section{Photographer William Pryor Floyd and the Images of the Duke of Edinburgh's}

\section{Visit}

In November 1869, Prince Alfred (Alfred Ernest Albert, 1844-1900), Duke of Edinburgh, visited Hong Kong during a tour of the Far East aboard HMS Galatea; he was the first British prince to visit this land. ${ }^{104}$ Even though William Beach, the Anglican Colonial Chaplain to Hong Kong, commissioned John Thomson to provide seven original photographs for a commemorative volume, The Visit of His Royal Highness the Duke of Edinburgh to Hong Kong in 1869, both Thomson and British photographer William Pryor Floyd were assigned to photograph the Prince's visit. ${ }^{105}$ This scrapbook contains two group portraits (0111 and 0112), that include the Prince, and a further ten photographs (0001-0005, 0113, 115-118) are believed to be related to this trip.

\section{a. Photographer William Pryor Floyd}

Similar to Milton Miller, William Floyd, who was born in Phillack, Cornwall in 1834, was also a talented portrait photographer and successfully established his own "Chinese portrait type.”106 In addition to portraits, he also made excellent architectural and scenic images. During the late 1860s, Floyd and Chinese photographer Afong were Thomson’s major competitors in Hong Kong.

Floyd's personal life and background are still unknown. In terms of his "high standard" and “distinguished photographic career” in China, Floyd moved to Macau in 1865 and set up a photographic studio, which burned down the following year. ${ }^{107}$ In late 1866 or early 1867, he joined the Silveira \& Co. in Hong Kong, and soon became its owner. ${ }^{108}$ On April $8^{\text {th }}$, he

\footnotetext{
${ }^{104}$ Rev. William Roberts Beach, The Visit of His Royal Highness the Duke of Edinburgh to Hong Kong in 1869, $2^{\text {nd }}$ ed (Hong Kong: Noronha and Sons, Government Printers, 1870).

105 Bennett, 1861-1879, 222.

106 Ibid, 7

107 Ibid, 7-8.

108 Ibid, 8.
} 
established Floyd \& Co. at 62 Queen’s Road Central, Hong Kong, ${ }^{109}$ where Afong's and later Thomson's studios were also to be found. ${ }^{110}$

The photography market competition in late nineteenth-century Hong Kong was fierce. Western photographers (such as Thomson, Floyd, and Miller) and Chinese photographers (such as Afong and Pun Lun) all contributed to their energies to the competitive atmosphere. While Thomson sought to publish his images widely and cooperated with China Magazine, Miller had achieved unrivalled success in the area of portraiture. ${ }^{111}$ Afong and Pun Lun not only attracted both Chinese and foreign residents, but also gained government assignments which included providing passport photo services. ${ }^{112}$ Facing these competitors, Floyd launched a price and technology war. He not only offered lower prices, but he also introduced the new wide-angle camera-lens technology (a Dallmeyer and Ross lens) to the Hong Kong market. $^{113}$

\section{b. The Images Related to the Prince's Visit}

By comparing the Prince's portrait in The Visit of His Royal Highness ${ }^{114}$ to the figures in the group portraits 0111 and 0112, it appears that both include Prince Alfred, the Duke of Edinburgh. In the following illustrations, the individual circled in red is believed to be the Prince.

\footnotetext{
109 Ibid.

110 Ovenden, John Thomson, 143. Thomson’s studio was at no. 29 Queen’s Road, and Afong’s was at no. 54.

111 Bennett, 1842-1860, 169-193; Wu, “Inventing a 'Chinese’ Portrait Style.”

112 Bennett, 1844-1879, 66-98, 100-106.

113 Bennett, 1861-1879, 10-11.

114 Beach, The Visit of His Royal Highness, i.
} 
Illustration 14. Image 0111

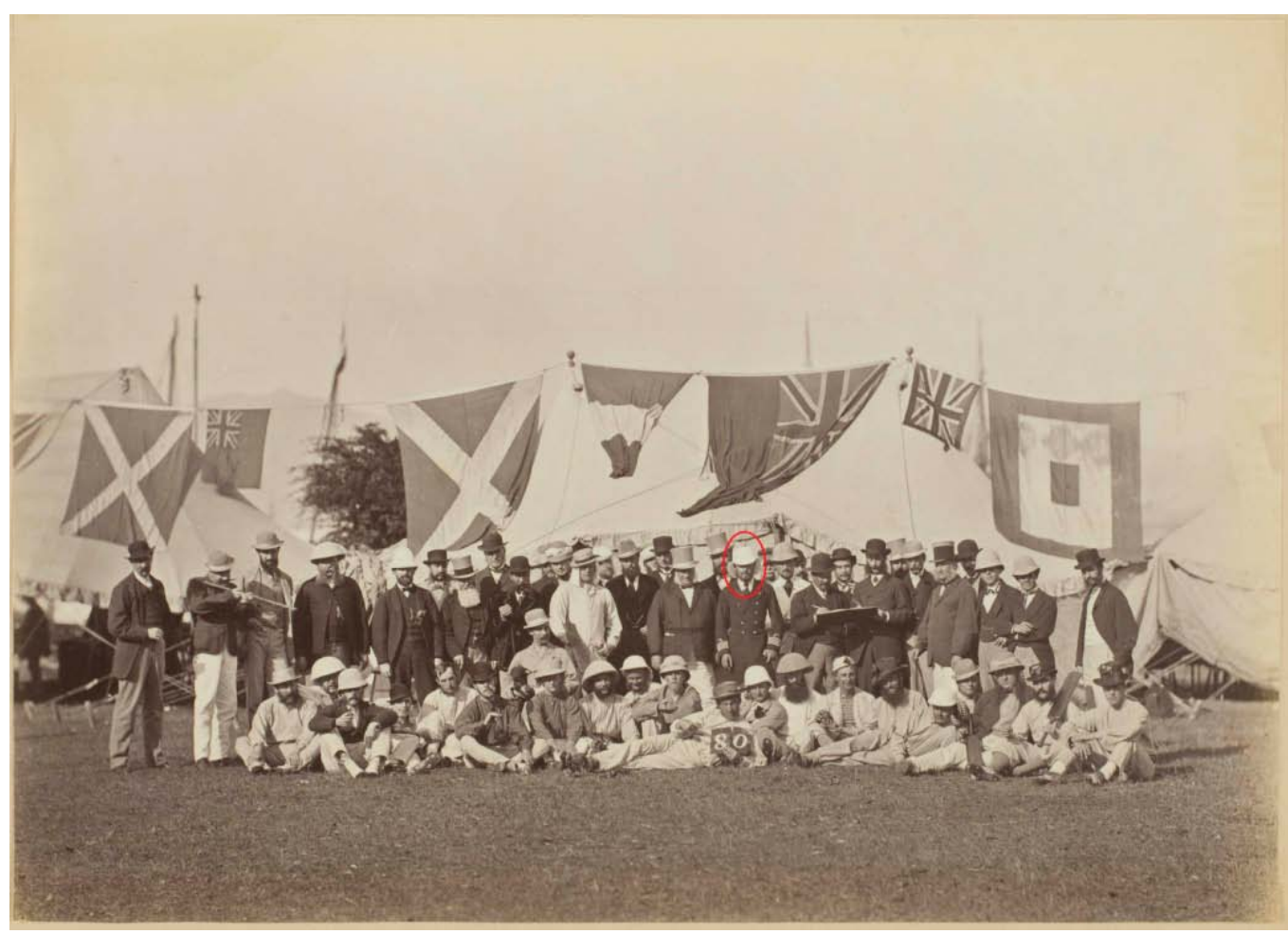

Illustration 15. Image 0112

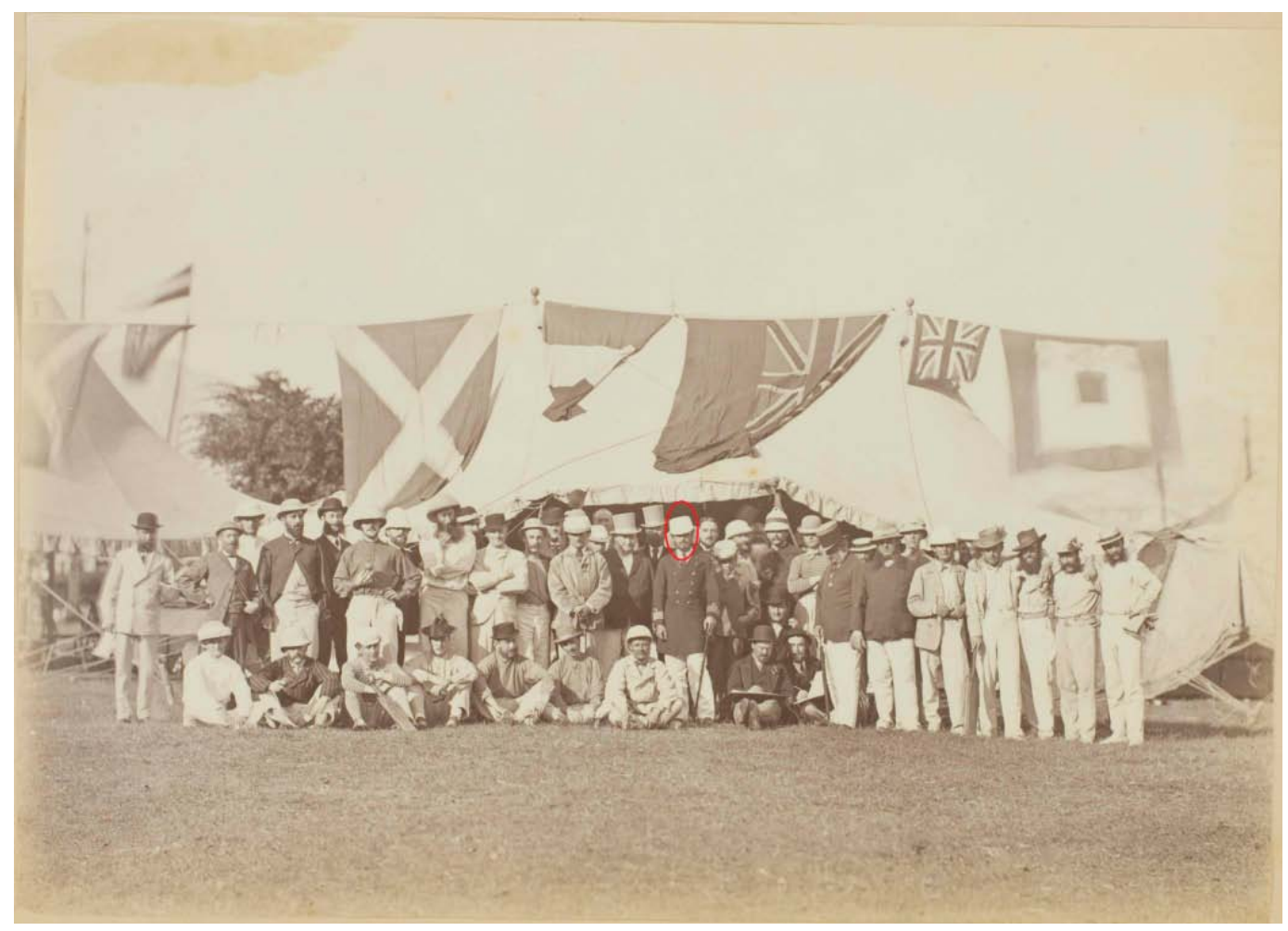


Illustration 16. Prince's Portrait in The Visit of His Royal Highness

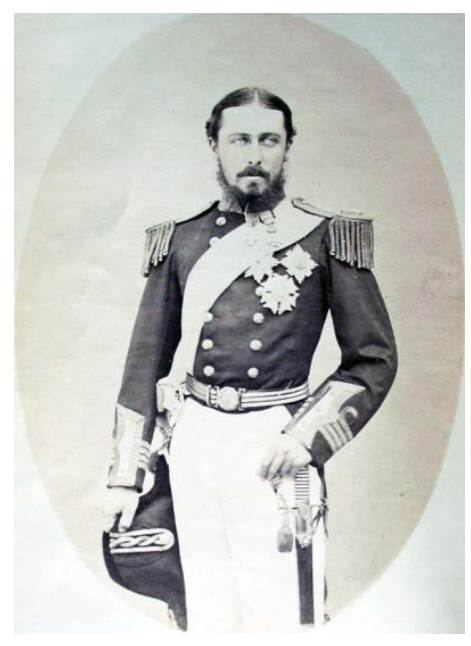

Illustration 17. Prince's Figure in 0111

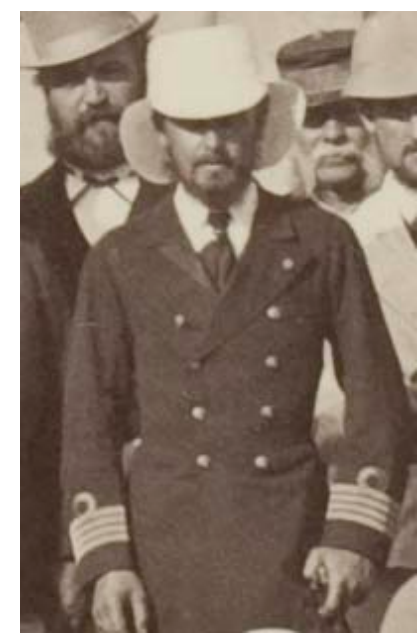

Illustration 18. Prince's

Figure in 0112

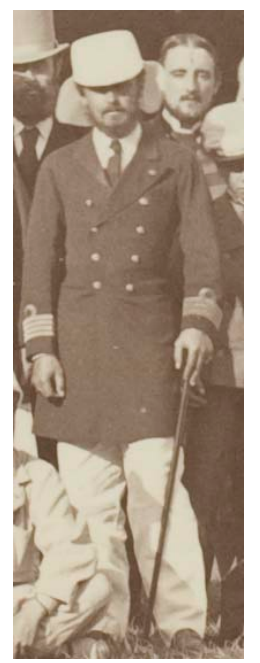

Photographs 0002, 0003, 0005, 0113, and 0115-0118 are also group portraits. The background for 0117 is the same as that for 0002, 0003, and 0005. Even though these photographs do not include the Prince, by comparing the figures in 0111 and 0112 one can see that some of the same figures appear in these images. It would thus, suggest, that these photographs were also taken during the Prince’s visit. The two figures in the individual studio portraits 0001 and 0004 also appear in these larger group portraits. Therefore, in total, there are twelve photographs in this scrapbook that are believed to have documented the Prince's visit, and none of them is signed. Since both Thomson and Floyd were the official photographers for the visit, an attribution for these twelve images to John Thomson cannot be made with any certainty, but these photographs are arguably the work of either a professional like them, or of an advanced amateur, and in any case, not intended for general sale.

Aside from the unconfirmed attribution, another question presented by the photographs of the Prince's visit is how these photographs entered into this scrapbook. After the Prince’s visit, both Thomson and Floyd offered the Prince's portraits for sale. ${ }^{115}$ It is unlikely that the group portraits, whether or not they include the Prince, would be marketable ones. The

115 Bennett, 1861-1879, 222. 
images sold were either the studio portraits of the Prince, or the landscapes and scenic images associated with his visit such as those published in The Visit of His Royal Highness.

From an aesthetic point of view, the quality of some of the images does not reflect the quality that a typical souvenir photograph should have. Taking 0118 as an example, many of the figures in the image are blurred or out of focus. In the lower left corner, there is a local man who does not seem to belong in the group portrayed, but who was nevertheless photographed.

\section{Illustration 19. Image 0118}

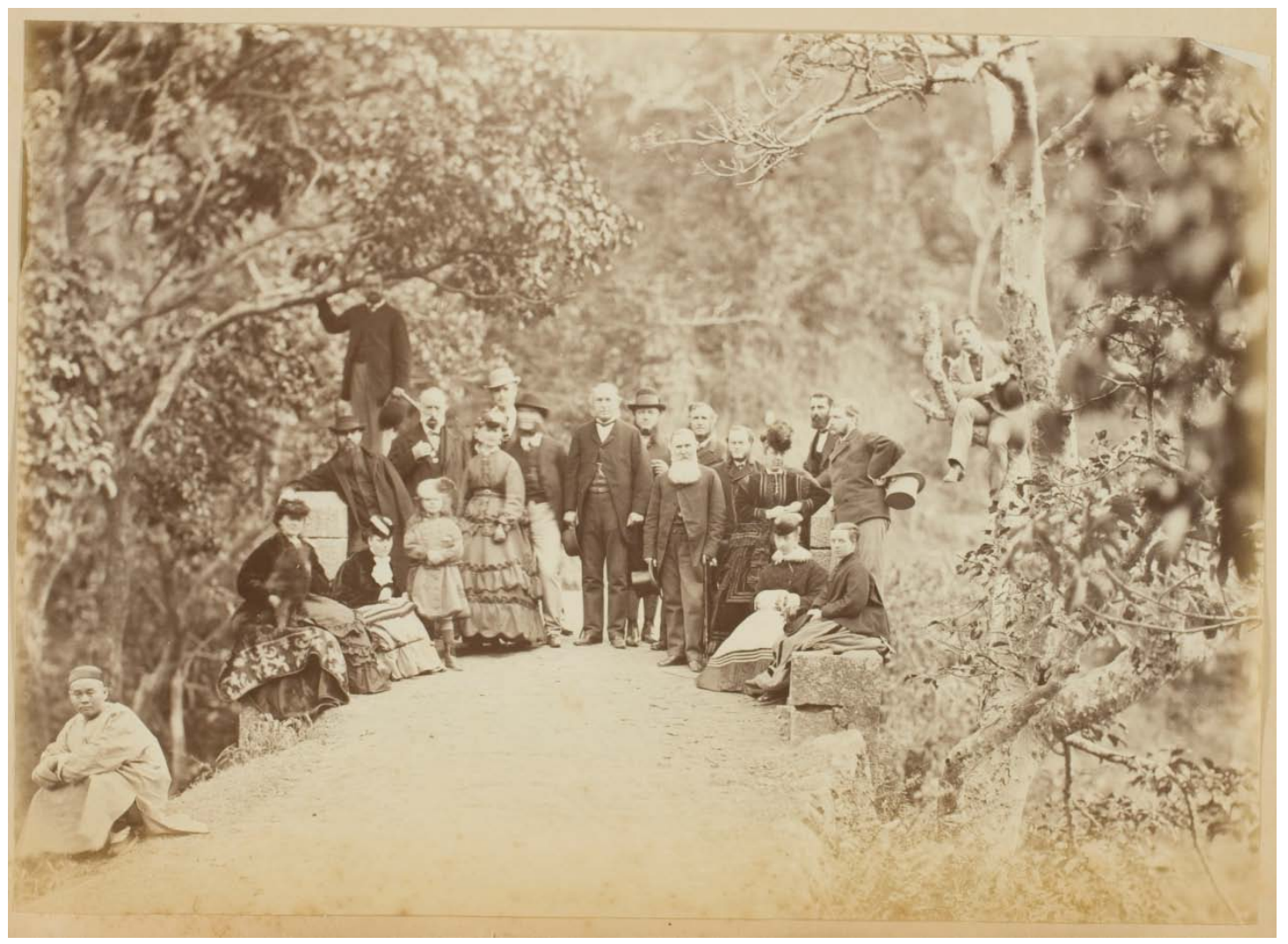

\section{The Survey Photographs}

In this scrapbook, there are five photographs, 0119-0123, that are believed to be survey photographs, which were likely taken for a government assignment. They are all of Pokfulam, Hong Kong. The inscription for 0119 reads “Block House Telegraph Pokfulam HKong”; 0120 reads “Ganey Pokfulam”; 0121 reads “Ganey Telegraph Testing House 
Pokfulam H Kong”; 0122 reads "Pokfulam H Kong Bay where the cable is landed”; and 0123 reads “Pokfulam H Kong.”

Pokfulam is an area on Hong Kong Island. ${ }^{116}$ The Telegraphy Bay, or Kong Sin Wan, Tai Hau Wan, where the first Hong Kong telegraph cable was linked overseas in 1871, is also located in this area. ${ }^{117}$ According to the inscriptions, it is reasonable to believe that these photographs were meant to record the installation of the first telegraph cable in Hong Kong.

\section{Illustration 20. Image 0119}

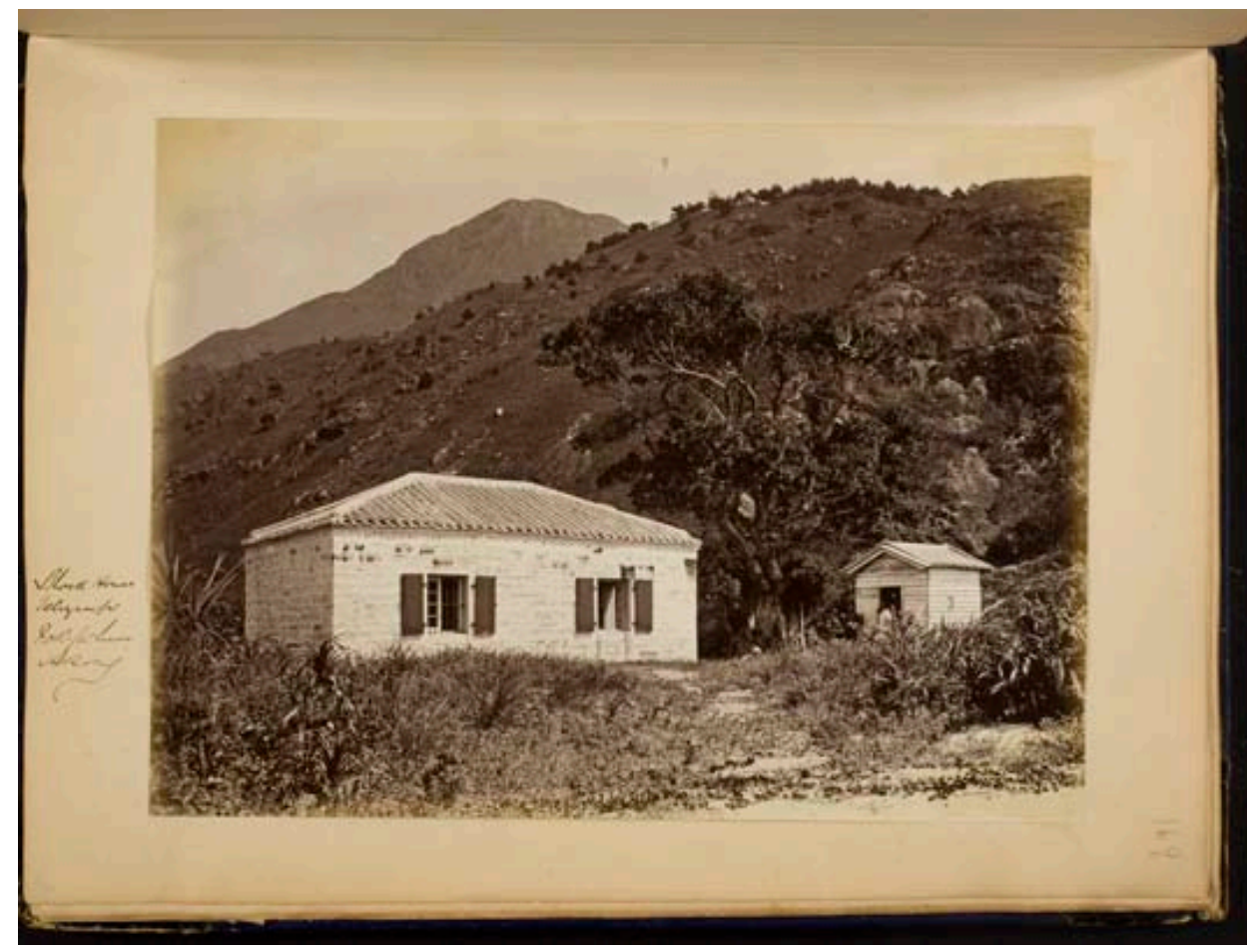

116 Wikipedia, “Pok Fu Lam,” last modified on 6 April 2014, accessed July 11, 2014, http://en.wikipedia.org/wiki/Pok_Fu_Lam.

117 Wikipedia, “Telegraph Bay,” last modified on 7 September 2013, accessed July 11, 2014, http://en.wikipedia.org/wiki/Telegraph_Bay. 


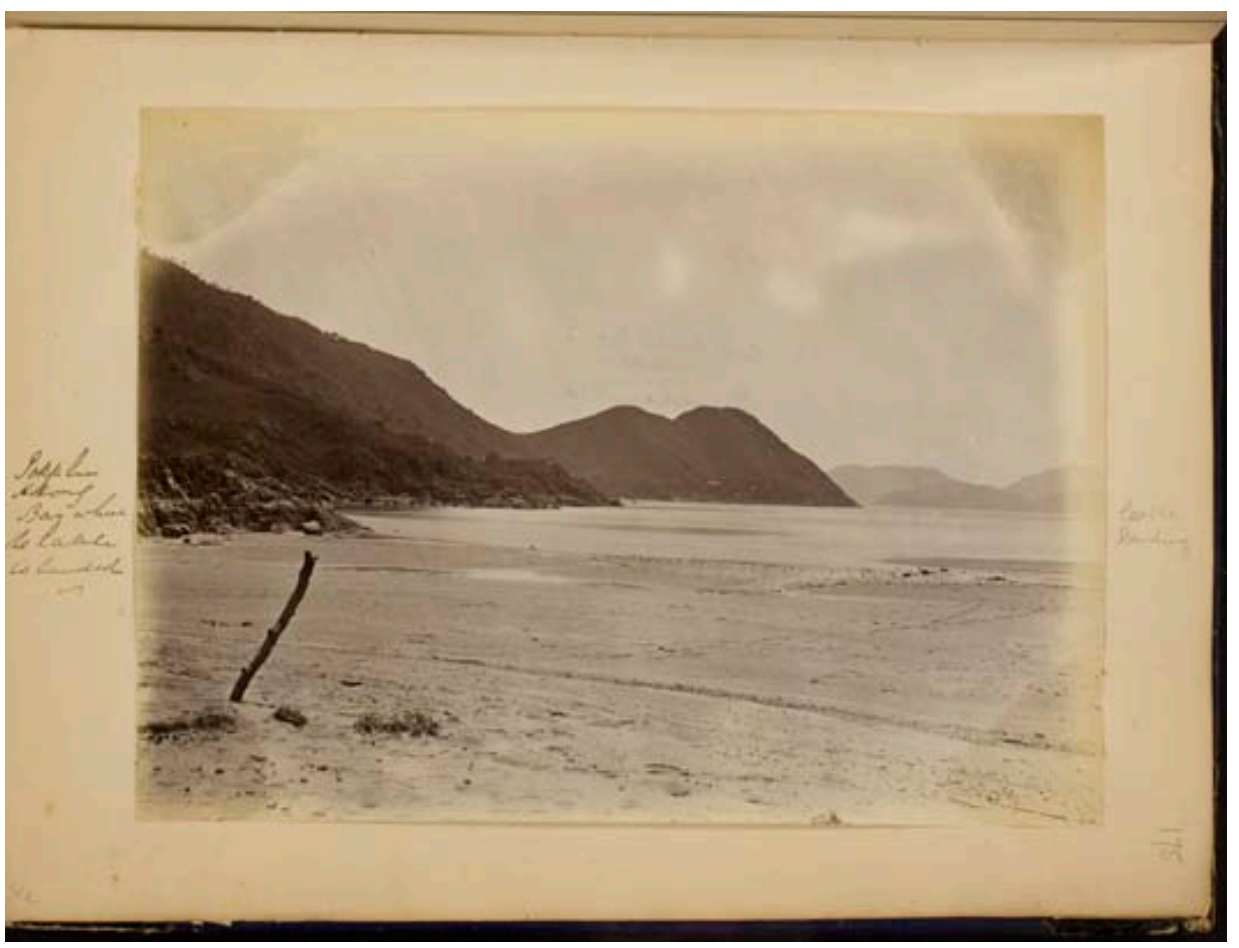

Survey photographs, in general, are not made for sale but rather, for documentary use, which is believed to be the same situation here: these five photographs do not focus on the scenic landscape. Taking 0122 as an example, when photographing the sea, the photographer did not present the vast and becalmed ocean or the relationship between the mountains and the water. What these photographs focus on are the shape of the lonely telegraph testing house, its location, and the surrounding environment of mountains and the nearby bay. These photographs were not likely to appear in the souvenir market, and the survey photographs in general rarely appear in a typical nineteenth-century souvenir travel album. 


\section{Conclusion}

The attribution of unidentified nineteenth-century Far East photographs is a difficult matter in general. Numerous amateur and professional photographers visited the Far East to seek commercial opportunities and memorable adventures. They traveled widely and took countless photographs. Today, the majority have already been forgotten. Alternatively, they have not been forgotten, but their works cannot be attributed with certainty.

There are many reasons for this. For example, Hong Kong, which was an important port, was visited by a good number of photographers who achieved brilliant successes in the history of Far East photography. Numerous eminent Chinese photographers also established their photographic careers in the Hong Kong area. Their names and works should be remembered and studied. However, the war, the immature market system, and even the practices of the photographers themselves created conditions which made the early history of Hong Kong photography unclear. Moreover, during World War II, paper documents, archives, and newspapers were either lost or destroyed. Even before that, when the negatives and prints were made, the attribution for some was destined to be forgotten: the majority of the photographers in Hong Kong during that time period did not sign their works. ${ }^{118}$ Since so much time has passed, definite attribution for many of these images is virtually impossible.

Making matters much worse was the emergence and development of The Firm ${ }^{119}$. A great numbers of negatives were left behind as photographers closed their studios and moved away. The accumulation of these negatives provided photographers such as Milton Miller, William Floyd, Emil Rusfeldt, and Afong, the successive “owners” of The Firm, the

\footnotetext{
118 Worswick, "Photography in Imperial China," 149. “During the late 1860s and early 1870s, Thomson was the only photographer in Hong Kong to sign his name to his work (Miller's signature had been cropped out when the copy negatives of his prints were made)...”

119 Ibid, 139. The Firm is a concept created by Worswick. He writes "The Firm was not an actual commercial entity but rather a huge collection of negatives left behind by all the photographers who had ever arrived in Hong Kong, set up shop, and then gone bankrupt. In time, The Firm would come to include the stockpiles of eleven photographic establishments that attempted to do business in Hong Kong from 1860 to 1877. As succeeding photographers went out of business, their stock would be assumed by the next professional photographer who believed that he alone knew the secret of establishing a solid clientele in South China...”
} 
opportunity to print negatives made by others and thus to take credit for the images. For example, Floyd printed Thomson's work; Rusfeldt printed both Thomson's and Floyd's works; and Afong printed Beato’s works, without mentioning that the negatives were made by other, and in many cases lesser known photographers. ${ }^{120}$ This makes a positive attribution for an early Hong Kong photograph highly questionable and most of the time impossible, as we do not know whether it was printed by the maker of the negative or the later photographer who had access to the negatives. Even though there might be an attribution associated with the print, we do not know for certain whether the printer acknowledged or gave credit to the original photographer or did not.

The question of attribution of an unsigned and even of a signed photograph is often complicated. As such, the conclusion of this thesis is that this scrapbook was likely not compiled by photographer John Thomson or owned by him. Whoever assembled it, and whoever the photographer(s) was (or were) remains unknown.

Nevertheless, from an institutional and scholarly perspective, this thesis is still meaningful. Indeed, the practical focus of this project, which is about compiling research results, comparing them with the George Eastman House cataloguing records, and improving and correcting the object level records, provides more accurate information about this scrapbook. This will benefit future researchers in terms of the scrapbook itself, John Thomson scholarship, and the history of Far East photography in general. The records' improvement presents the following information for the first time: the confirmed attributions, which were researched and determined by consulting the reliable sources and matching the findings with the prints, the detailed and specific photographic locations, the suggested time period during which the photographs were made, and the transcription of both the recto and the verso inscriptions from the photographs themselves. In what is hoped will be a significant

${ }^{120}$ Worswick, “Photography in Imperial China,” 140, 142, 149; Bennett, 1861-1879, 22. 
way, this thesis, together with the catalogue records, will serve as an aide for thoroughly understanding this intriguing scrapbook. 


\section{Appendix 1.}

\section{The Different Numbering Systems and Inscriptions Present in This Scrapbook}

This scrapbook includes three numbering systems that were and are still used by George Eastman House from the time that the object was received into the collection. The four-digit number on the lower left of the page 0 is one of the numbering systems that the Eastman House once used, which indicates that the photographs in the scrapbook were related to the Far East or Australia. The number below is the accession number for the scrapbook. The numbers in pencil in the upper right corner of the right-hand pages are the page numbers. The numbers in pencil in the bottom right corner of the right-hand pages are the (abbreviated) accession numbers of the print(s). There are two kinds of inscriptions in this scrapbook: the inscriptions written in ink date from the nineteenth century, and the ones in pencil were added by the donor, Alden Scott Boyer, probably in the late 1940’s. 


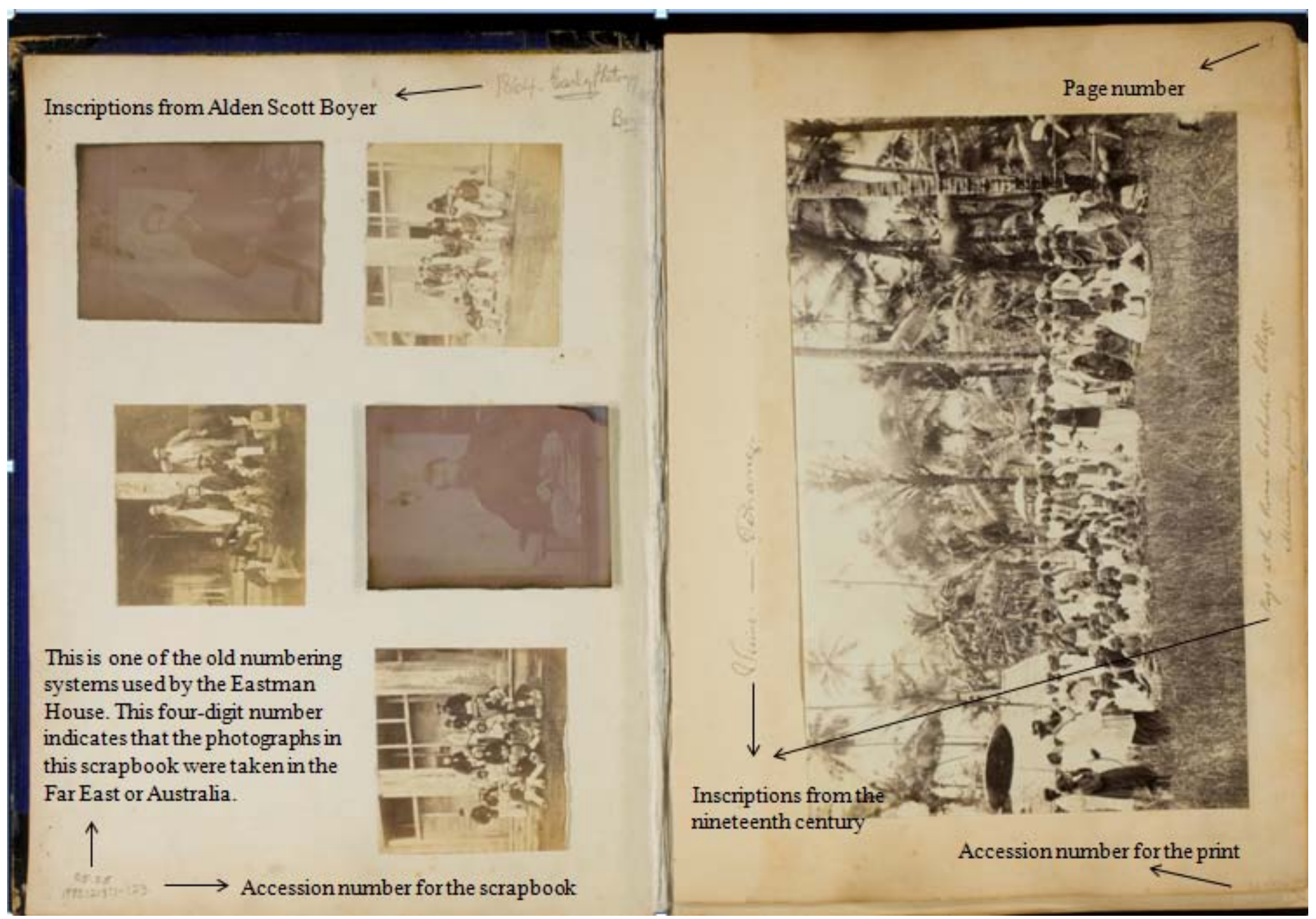




\section{Appendix 2.}

\section{Comparing Handwriting}

One of the difficulties in comparing handwriting is that, if inscriptions in this scrapbook were made by Thomson, they would probably have been written no later than when he was 35 years of age, that is, before he left Hong Kong. The samples provided by the Wellcome Library were from his later years.

\section{Handwriting from Scrapbook}
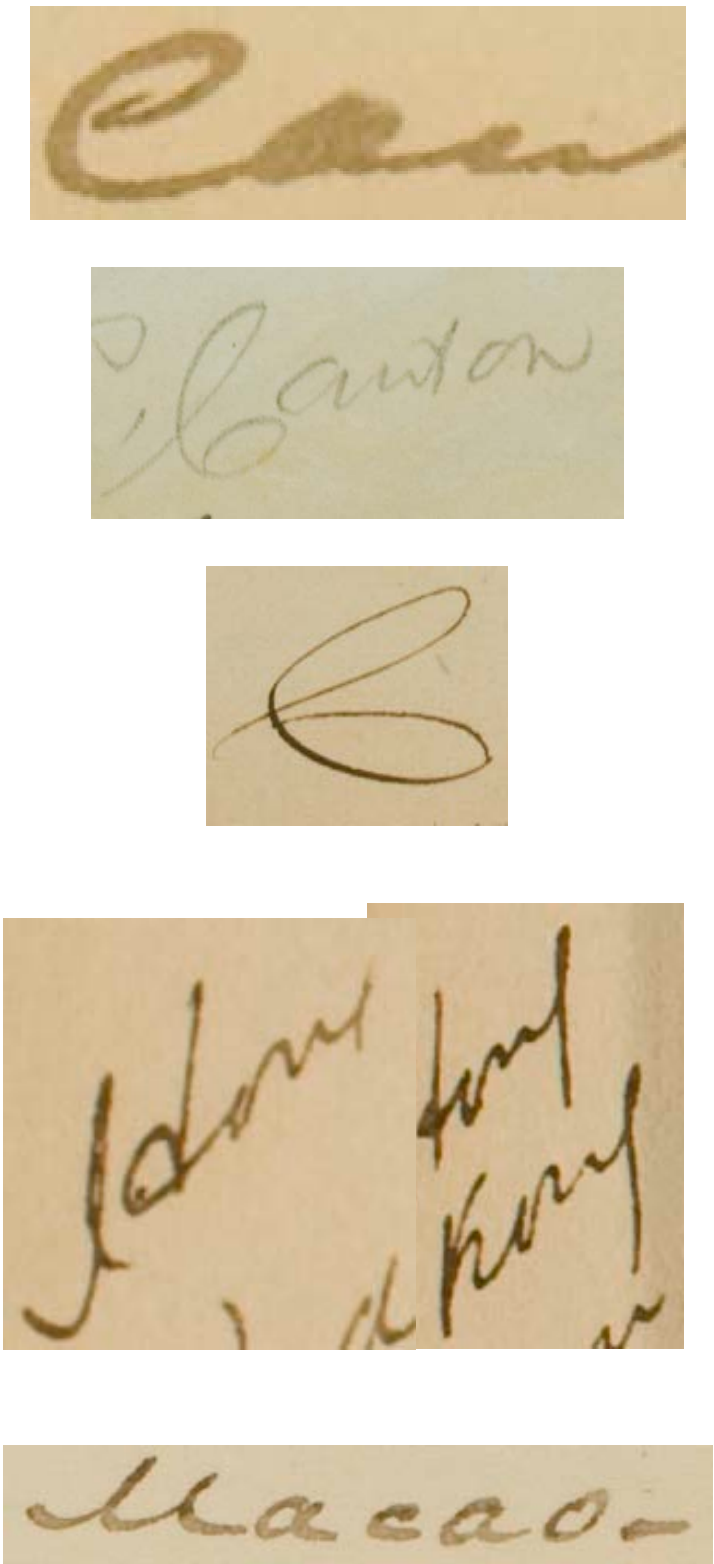

\section{Handwriting Provided by Wellcome \\ Library, London}
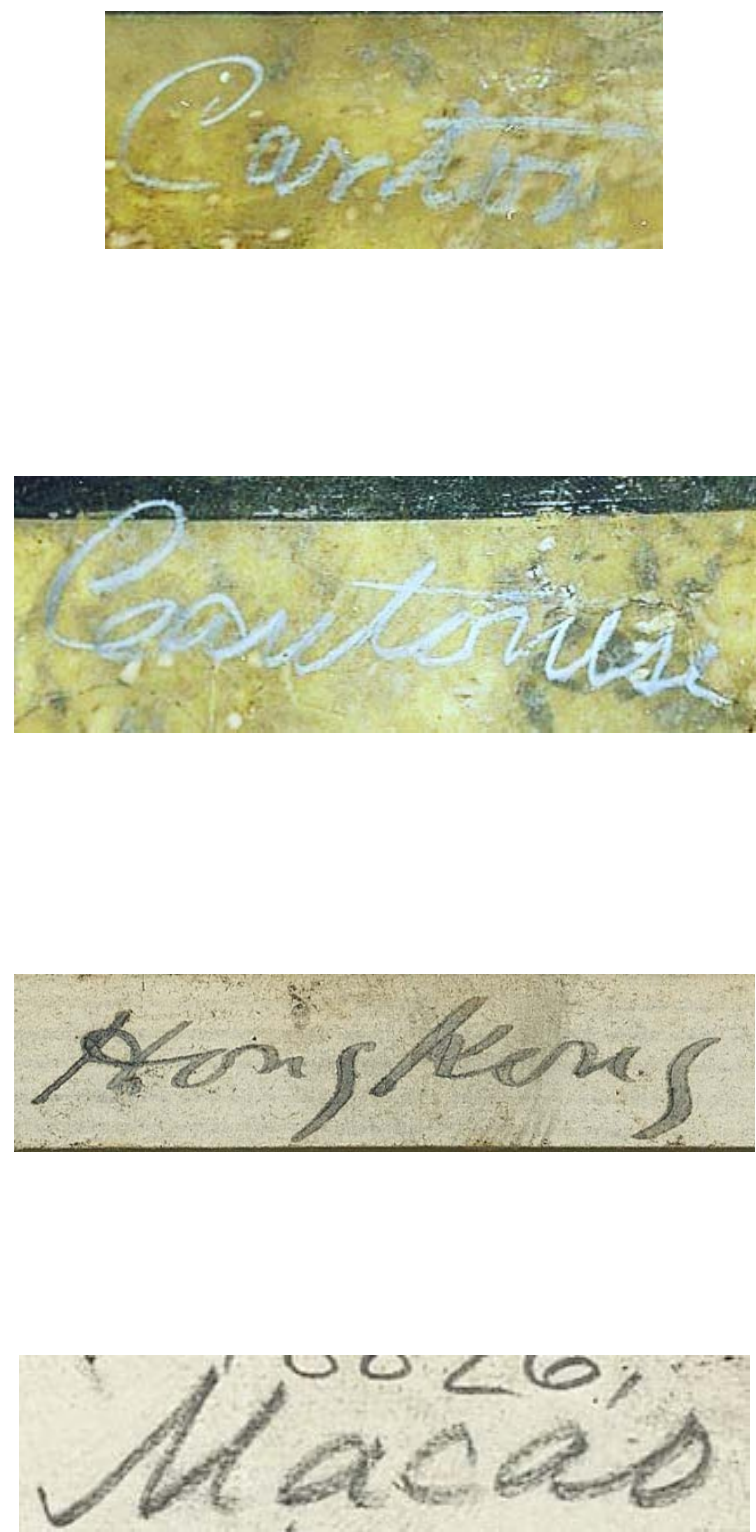


\section{Appendix 3.}

\section{Matching Results and Catalogues}

This part is a catalogue record of the thirty-three photographs from the scrapbook that can be attributed to John Thomson, a determination which was based on matching the images in the scrapbook with confirmed Thomson works, and also in some cases, by examining whether a Thomson signature appears in the print, scratched through the surface of the collodion coating.

This scrapbook was received by George Eastman House on September $6^{\text {th }}, 1950$ from the donor Alden Scott Boyer, but was given a new accession number in 1973. In that year, it was the $219^{\text {th }}$ object to be accessioned; therefore, the accession number of the images in the scrapbook begins with "1973:0219:. ” In the catalogue records that follow, the date field refers to the date that the negative was made, which is based on established the chronology of Thomson's Far East journeys, and the dimensions field refers to the dimensions of the prints. 


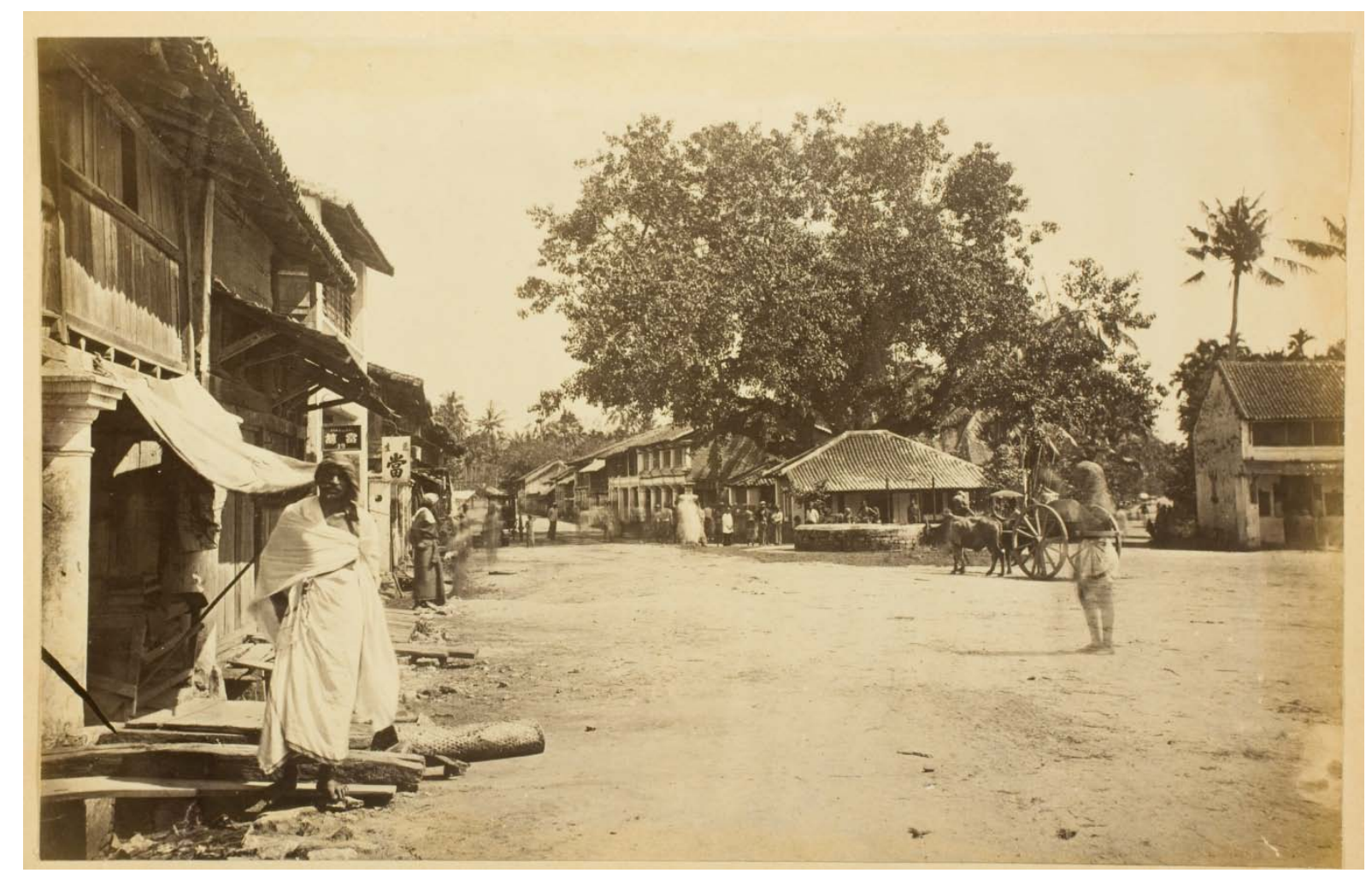

Accession No.: 1973:0219:0017

Page No.: 5

Date: $1862-1868$

Signature: no signature

Dimensions: 17.3 x $27.1 \mathrm{~cm}$

Inscriptions: recto on album page (ink from $19^{\text {th }}$ century hand): Main Street - Penang recto on album page (pencil from Alden Scott Boyer hand): 1864

References: Stephen White, John Thomson: A Window to the Orient, Plate 6.

Notes: White alone has attributed this image to Thomson, and it is not included in the surviving negatives at the Welcome Library, nor appeared in any of Thomson's publications, nor does it exist as a print in any known public collection. 


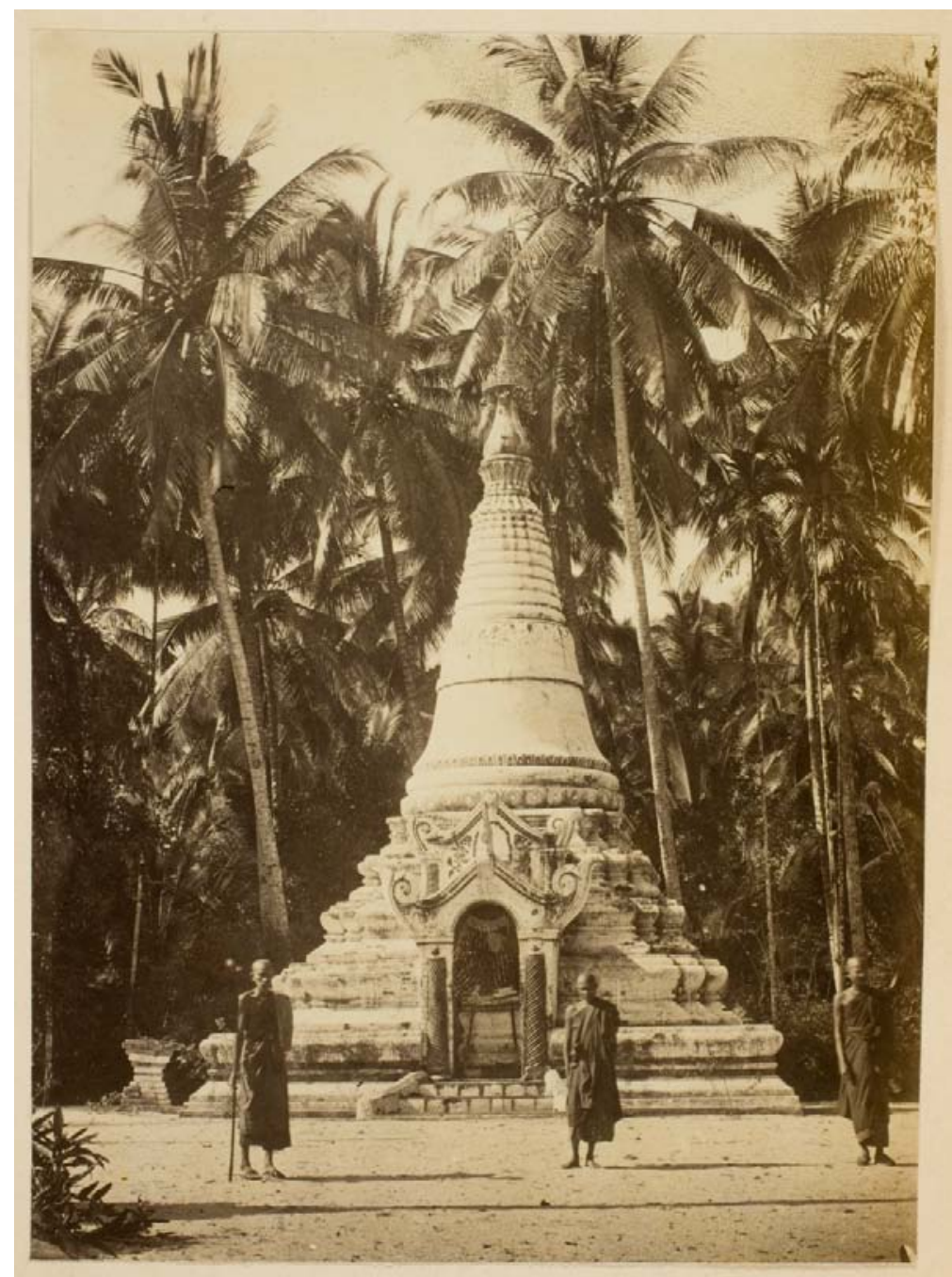

Accession No.: 1973:0219:0019

Page No.: 9

Date: $1862-1868$

Signature: no signature

Dimensions: 14.5 x $10.4 \mathrm{~cm}$

Inscriptions: recto on album page (ink from $19^{\text {th }}$ century hand): Siamese Temple

References: Special Collections at the University of Massachusetts Amherst, Temple, Penang, http://www.library.umass.edu/spcoll/ead/muph002.html\#.

Notes: The inscriptions on the mount of the Massachusetts prints are "Photo'ed by J. Thomson Penang" and "Nov. 1863." ${ }^{121}$

The special collection at the University of Massachusetts Amherst alone has attributed this image to Thomson, and it is not included in the surviving negatives at the Welcome Library, nor appeared in any of Thomson's publications.

\footnotetext{
${ }^{121}$ Kirstin Kay, Archivist at Special Collections, University of Massachusetts Amherst, e-mail message to author, March 13, 2014.
} 


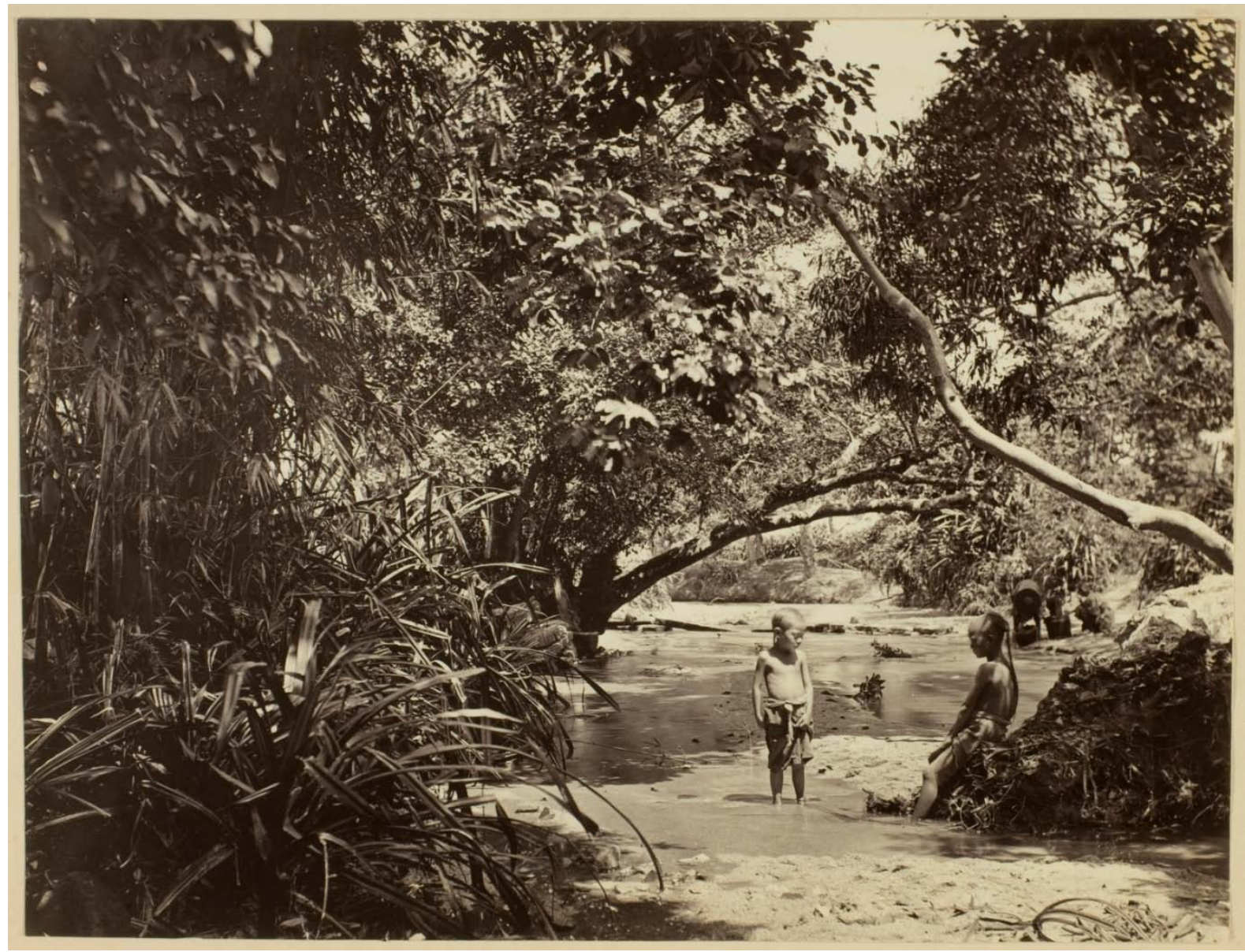

Accession No.: 1973:0219:0062

Page No.: 71

Date: $1862-1868$

Signature: no signature

Dimensions: 17.4 x $23 \mathrm{~cm}$

Inscriptions: recto on album page (ink from $19^{\text {th }}$ century hand): Singapore verso on print (ink from $19^{\text {th }}$ century hand): Singapore

References: Wellcome Library collection 19370i

http://search.wellcomelibrary.org/iii/encore/record/C_Rb1177248_S19370i Orightresult__U_X3?lang $=$ eng\&suite $=$ cobalt.

Stephen White, John Thomson: A Window to the Orient, Plate 16.

Notes: 


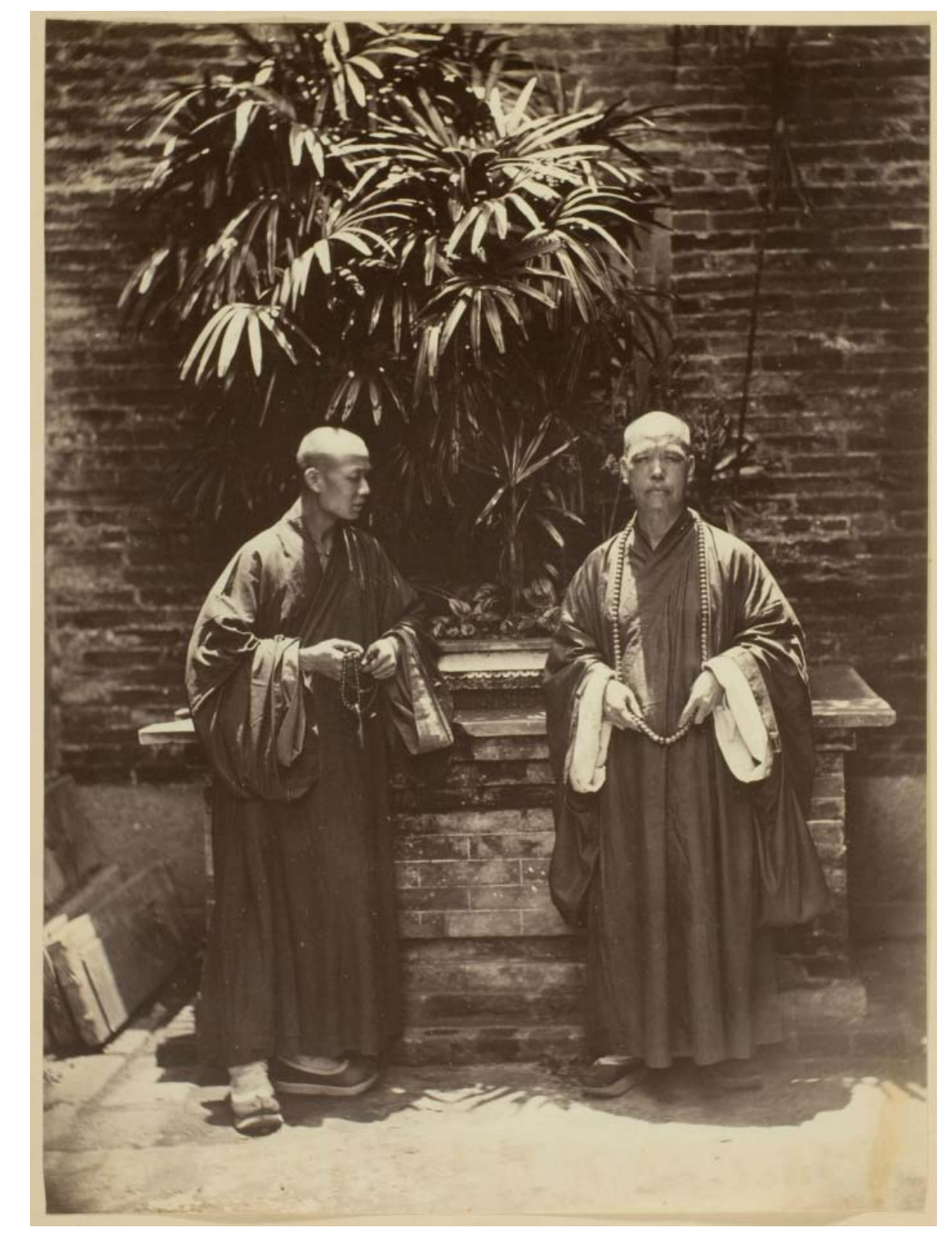

Accession No.: 1973:0219:0064

Page No.: 73

Date: $1868-1872$

Signature: no signature

Dimensions: 24.8 x $18.3 \mathrm{~cm}$

Inscriptions: recto on album page (ink from $19^{\text {th }}$ century hand): Priests. Canton. recto on album page (pencil from Alden Scott Boyer hand): China verso on print (ink from $19^{\text {th }}$ century hand): Priests of Wah Lum Chu / Canton

References: Wellcome Library collection 19526i

http://search.wellcomelibrary.org/iii/encore/record/C__Rb1177404_S19526i Orightresult____X3?lang=eng\&suite $=$ cobalt.

Beijing World Art Museum, China Through the Lens of John Thomson 1868 $-1872,151$ 
Stephen White, John Thomson: A Window to the Orient, Plate 69.

Notes: Wah Lum Chu (Canton) was built in 520 A. D. This is a famous and important Buddhist temple in southeastern China. The temple was built in the mountains. The name of the temple means "flying," which suggests the difficulties in building this temple. $^{122}$

${ }^{122}$ Baidu 百度, "Feilaisi (Guangdongsheng Qingyuanshi simiao)" 飞来寺(广东省清远市寺庙) [Wah Lum Chu, A Temple at Canton], last modified on 29 August 2013, http://baike.baidu.com/subview/508989/10244062.htm. 


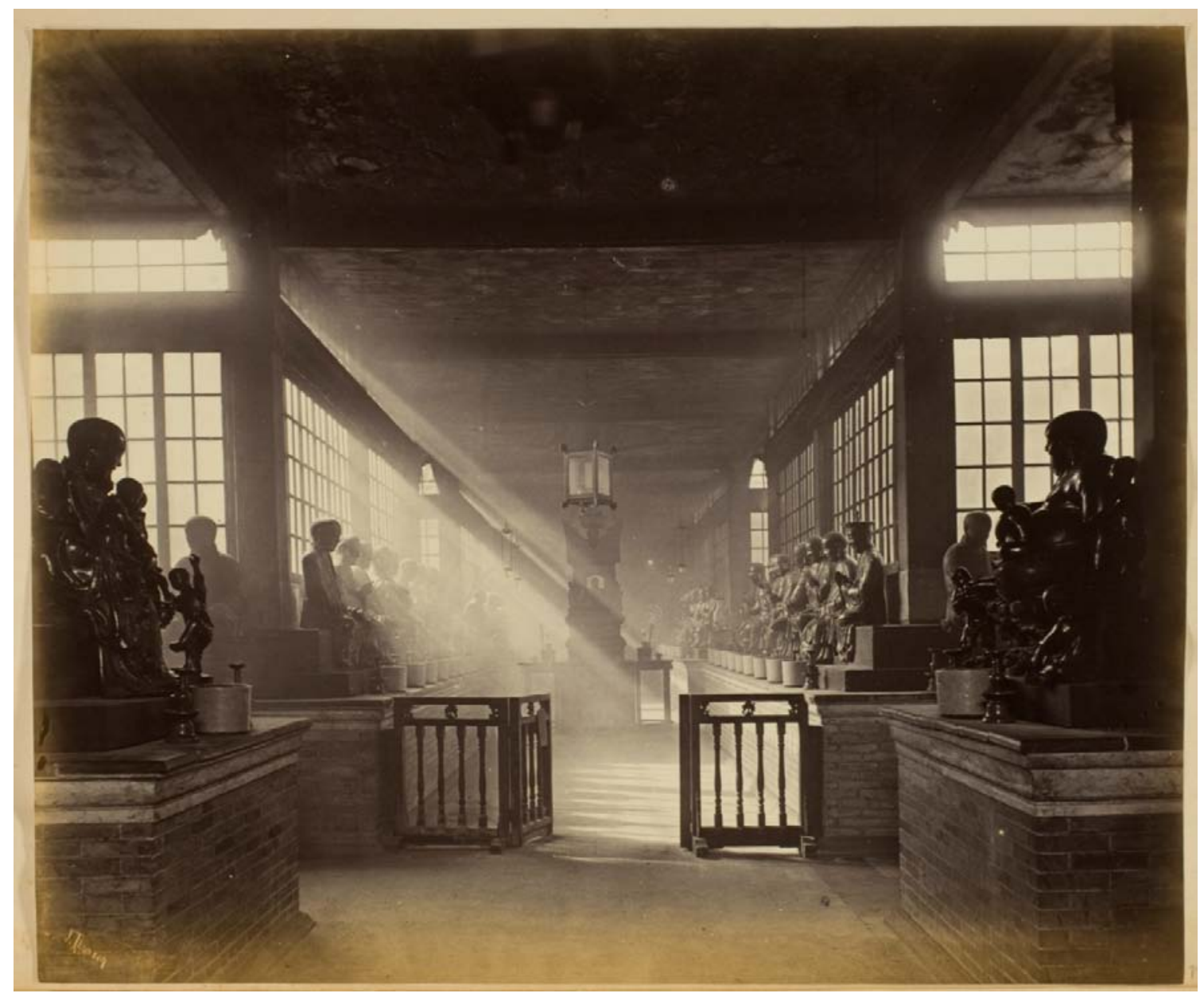

Accession No.: 1973:0219:0066

Page No.: 75

Date: $1862-1868$

Signature: Thomson's signature at lower left

Dimensions: 22.8 x $27.4 \mathrm{~cm}$

Inscriptions: recto on album page (ink from $19^{\text {th }}$ century hand): Wah Lum Chu Canton recto on album page (pencil from Alden Scott Boyer hand): China recto in print (white lettering, printed through from negative): J. Thomson verso on print (ink from $19^{\text {th }}$ century hand): Wah Lum Chu / Canton

References: Wellcome Library collection 19501i http://search.wellcomelibrary.org/iii/encore/record/C_Rb1177379_S19501i Orightresult_U__X3?lang=eng\&suite $=$ cobalt.

John Thomson, The Straits of Malacca, Indo-China, and China, 265, Temple of the Five Hundred Gods.

Notes: 


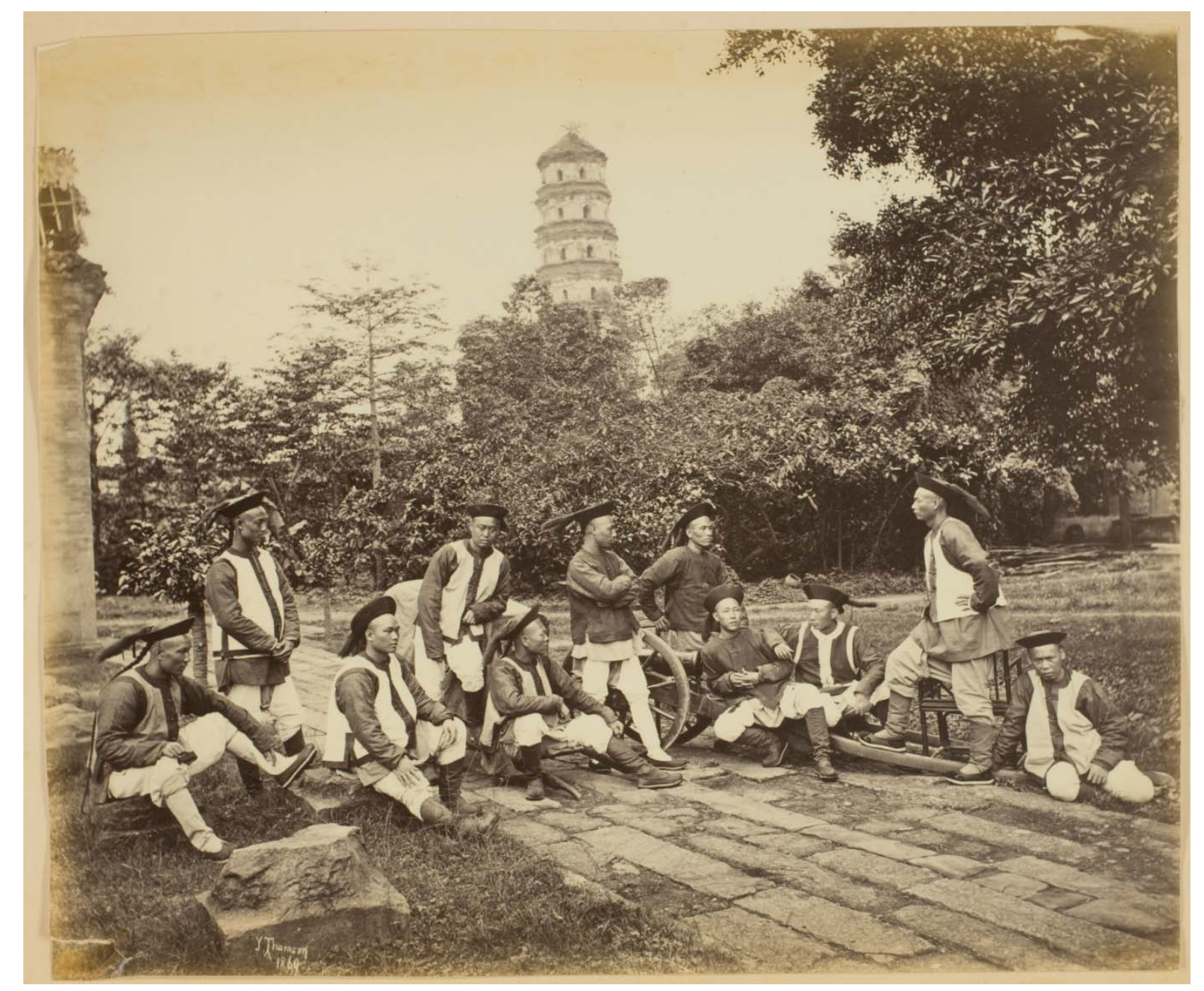

Accession No.: 1973:0219:0069

Page No.: 79

Date: 1869

Signature: Thomson's signature at lower left

Dimensions: 22.4 x $27 \mathrm{~cm}$

Inscriptions: recto on album page (ink from $19^{\text {th }}$ century hand): Tartars

recto on album page (pencil from Alden Scott Boyer hand): Tartars

recto in print (white lettering, printed through from negative): J. Thomson/

1869

verso on print (ink from $19^{\text {th }}$ century hand): Canton

References: Wellcome Library collection 19576i

http://search.wellcomelibrary.org/iii/encore/record/C_Rb1177454_S19576i

Orightresult____X3?lang=eng\&suite $=$ cobalt.

John Thomson, Illustrations of China and Its People, Vol. I, Plate XIV, TarTar Soldiers.

Notes: 


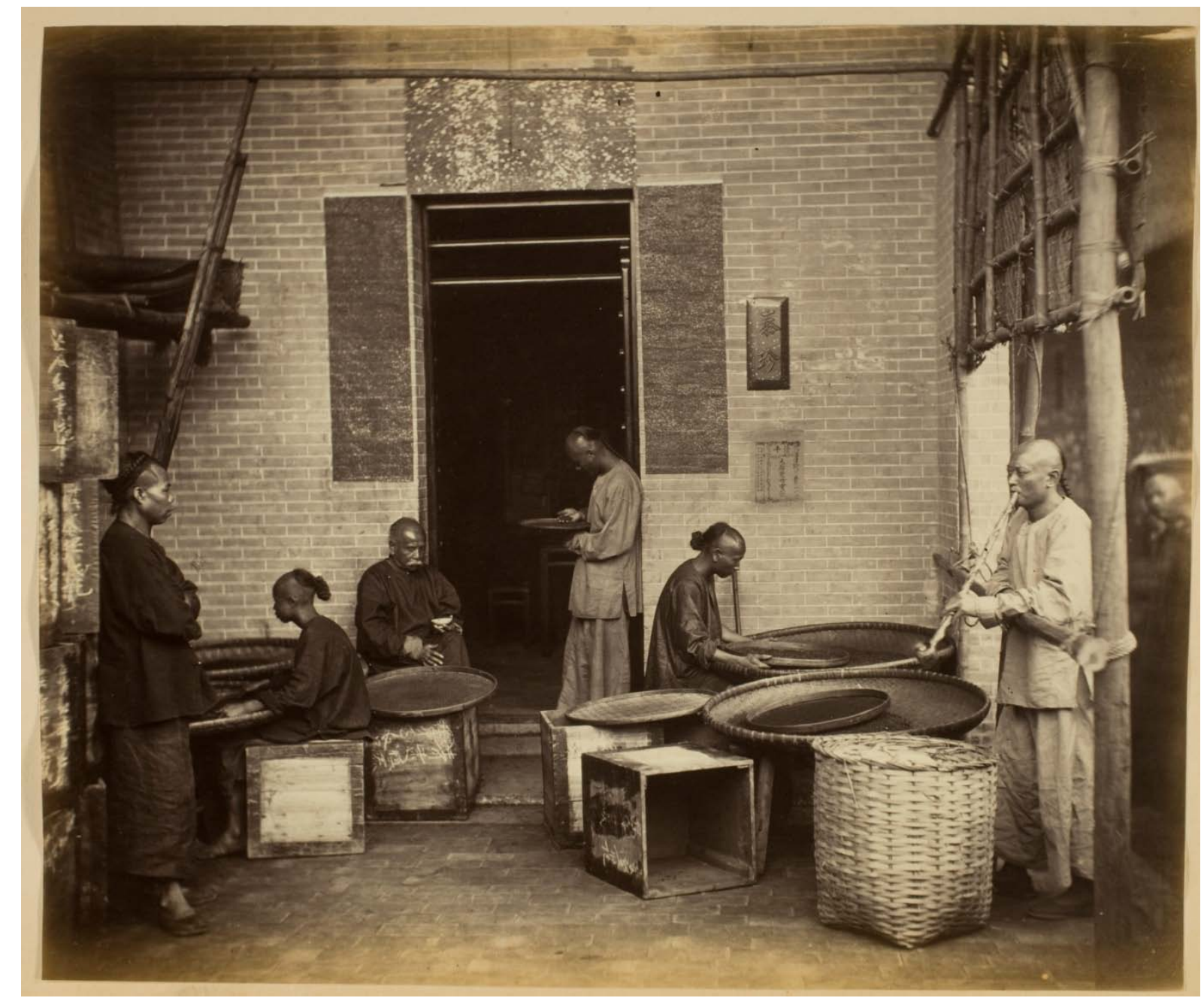

Accession No.: 1973:0219:0071

Page No.: 83

Date: $1862-1868$

Signature: no signature

Dimensions: 22.4 x $26.6 \mathrm{~cm}$

Inscriptions: recto on album page (ink from $19^{\text {th }}$ century hand): Tea/ Hous [sic]/ Canton recto on album page (pencil from Alden Scott Boyer hand): Tea House verso on print (ink from $19^{\text {th }}$ century hand): Tea House / Canton

References: John Thomson, Illustrations of China and Its People, Vol. I, Plate XXI, A Tea House, Canton.

Notes: 


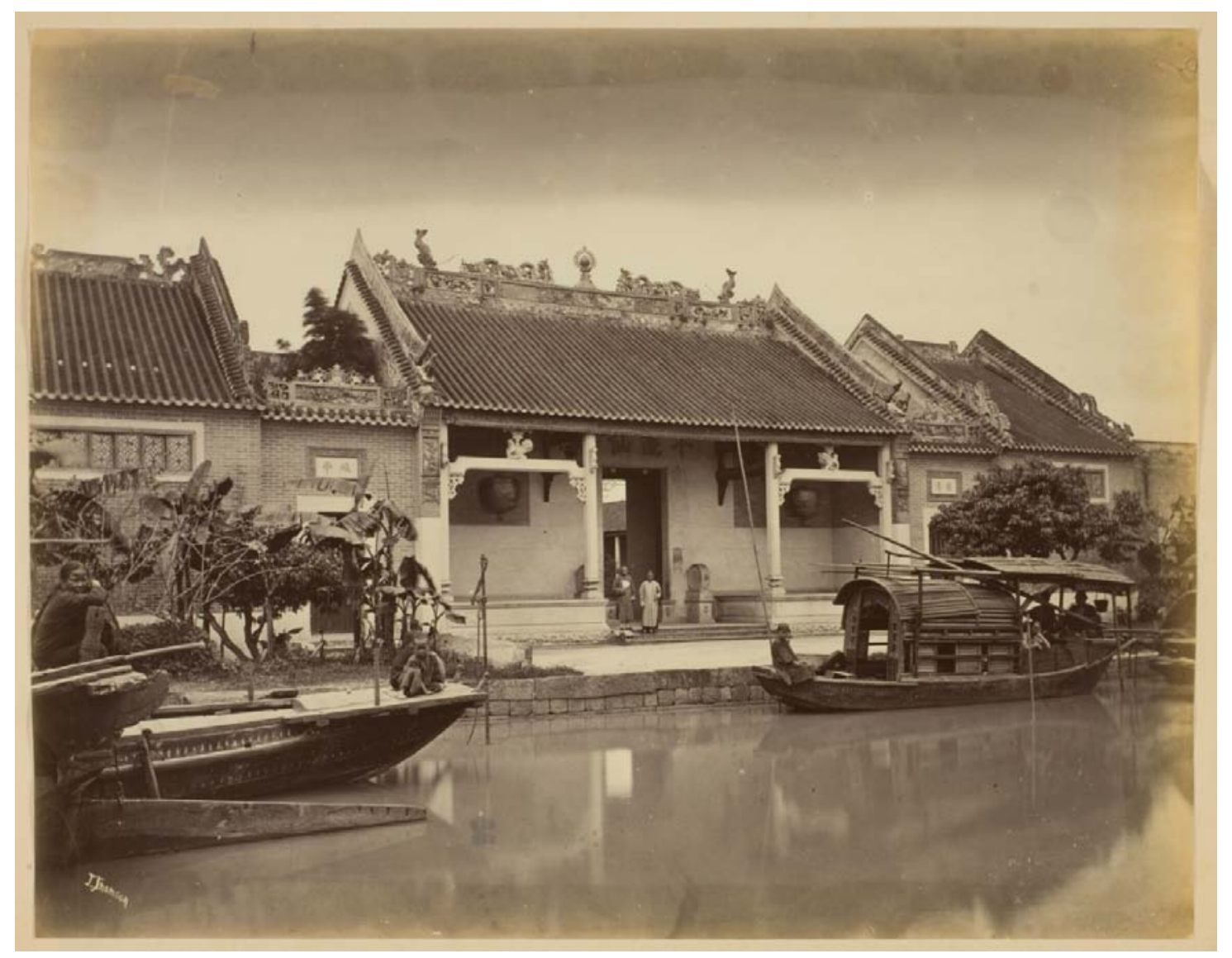

Accession No.: 1973:0219:0072

Page No.: 85

Date: $1862-1868$

Signature: Thomson's signature at lower left

Dimensions: 21.2 x $27.1 \mathrm{~cm}$

Inscriptions: recto on album page (ink from $19^{\text {th }}$ century hand): Yeh's Temple Canton recto in print (white lettering, printed through from negative): J. Thomson verso on print (ink from $19^{\text {th }}$ century hand): Yeh's Temple Canton

References: ${ }^{123}$

Notes: Yeh's Temple is the family temple for the famous Canton governor Ming-ch'en Yeh (1807-1859). However, this was a mistaken identification made by the photographer. Contemporary historians have confirmed that the temple in the photograph was a Taoist temple, named "Xiaopengxian Guan" (小蓬仙馆/Small Penglai Immortal Temple), rather than the Yeh family temple. ${ }^{124}$

\footnotetext{
${ }^{123}$ For the images with no associated references, the attributions were made based on John Thomson's signature appearing on the images.

${ }^{124}$ Henandi Wenhua Xueshe 河南地文化学社 [Henan Culture Society], "Yizhang Guangzhou laozhaopian yinfa de dili yian" 一张广州老照片引发的地理疑案 [A Geographical Mystery from an Old Canton Photo], Xinxi Shibao 信息时报 [Information Times], June 29, 2013, accessed February 10, 2014, http://informationtimes.dayoo.com/html/2013-06/29/content_2301981.htm.
} 


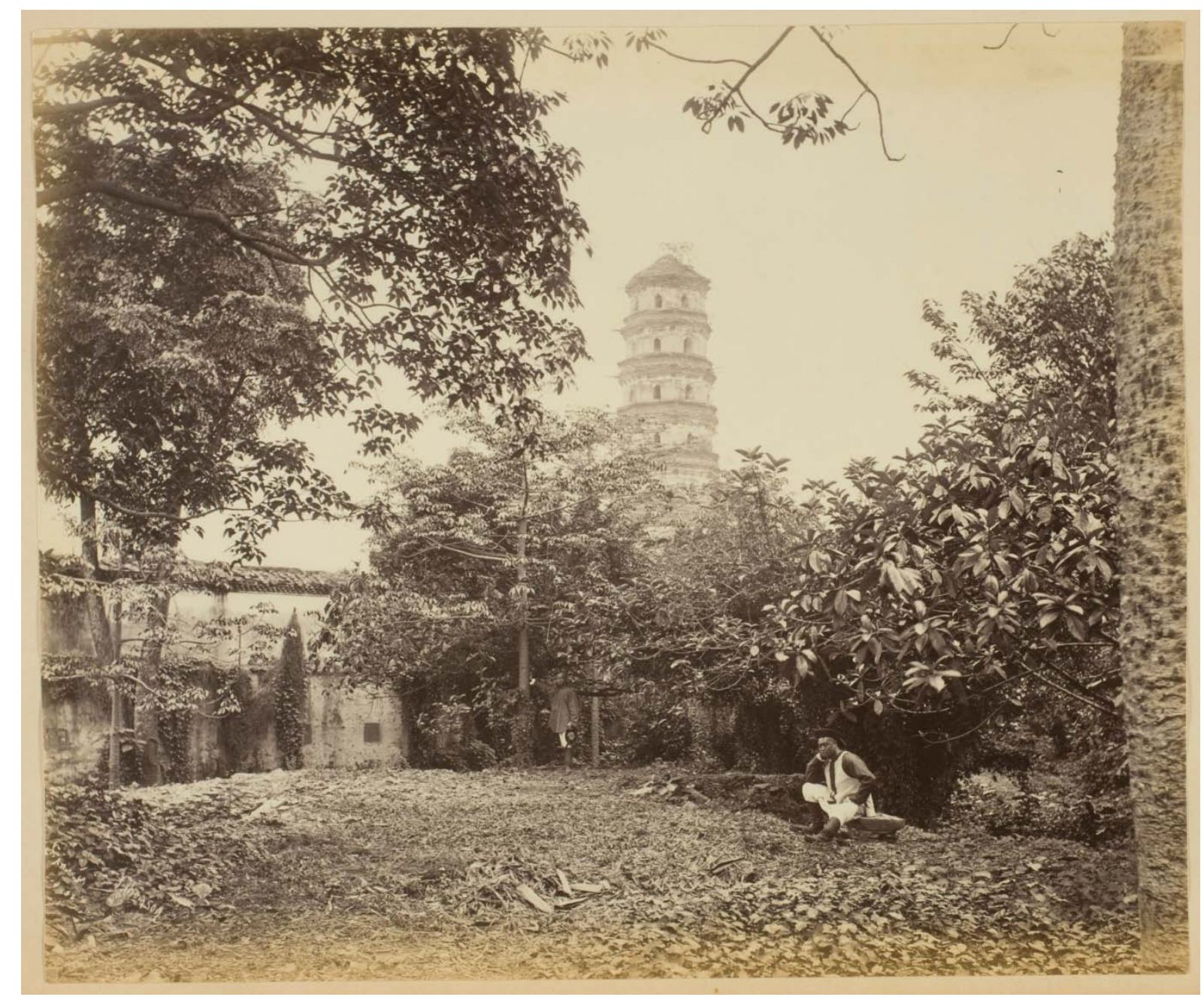

Accession No.: 1973:0219:0074

Page No.: 89

Date: $1862-1868$

Signature: Thomson's signature at lower left

Dimensions: 22.1 x $26.5 \mathrm{~cm}$

Inscriptions: recto on album page (ink from $19^{\text {th }}$ century hand): Consular / Garden / Canton recto in print (white lettering, printed through from negative): J. Thomson

\section{References:}

Notes: 


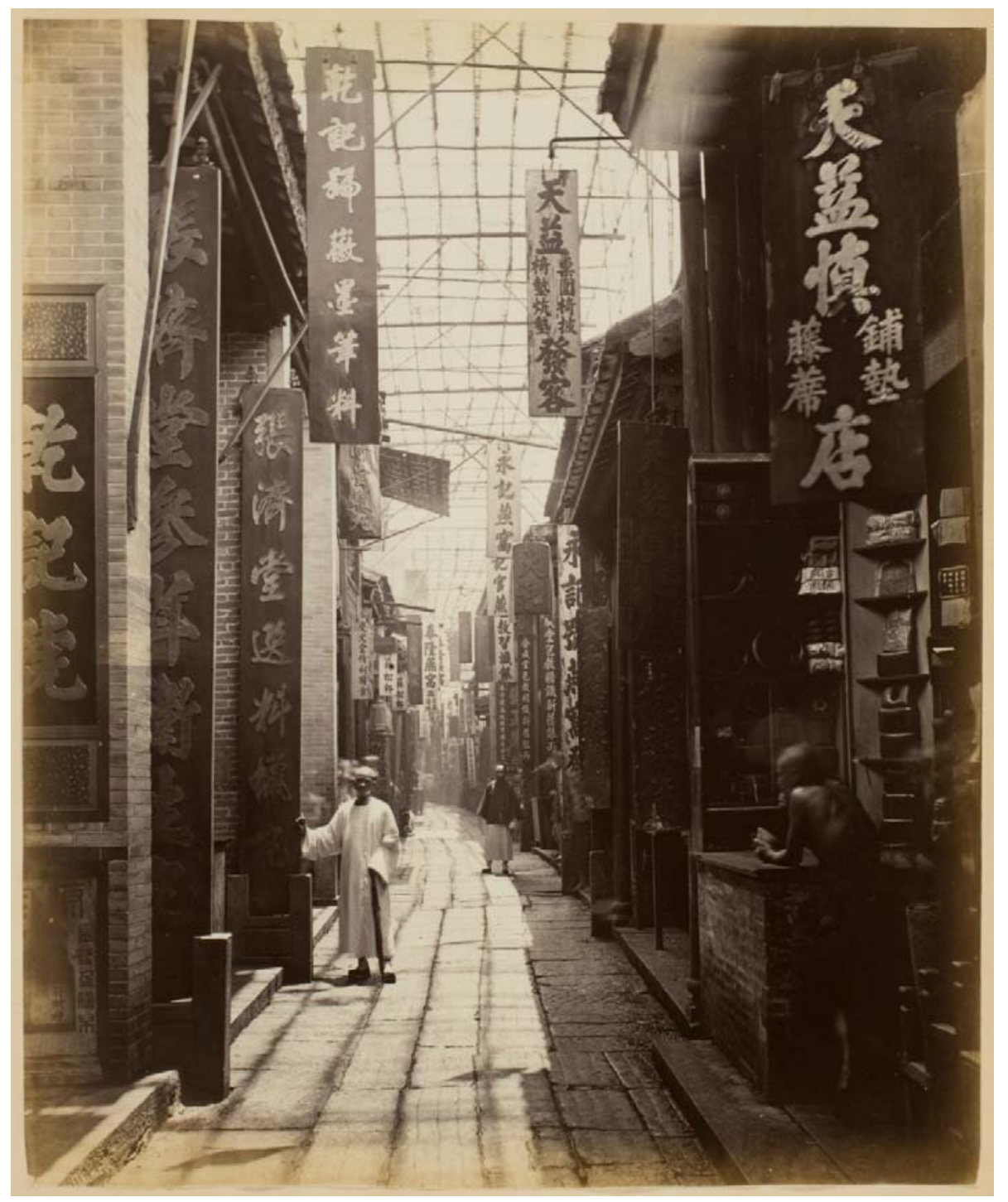

Accession No.: 1973:0219:0075

Page No.: 91

Date: $1862-1868$

Signature: Thomson's signature at lower left

Dimensions: 27.6 x $22.8 \mathrm{~cm}$

Inscriptions: recto on album page (ink from $19^{\text {th }}$ century hand): Physic St Canton recto in print (white lettering, printed through from negative): J. Thomson verso on print (ink from $19^{\text {th }}$ century hand): Physic Street / Canton

References: John Thomson, Illustrations of China and Its People, Vol. I, Plate XX, Physic Street, Canton.

John Thomson, The Straits of Malacca, Indo-China, and China, 249, A Street in Canton.

Notes: 


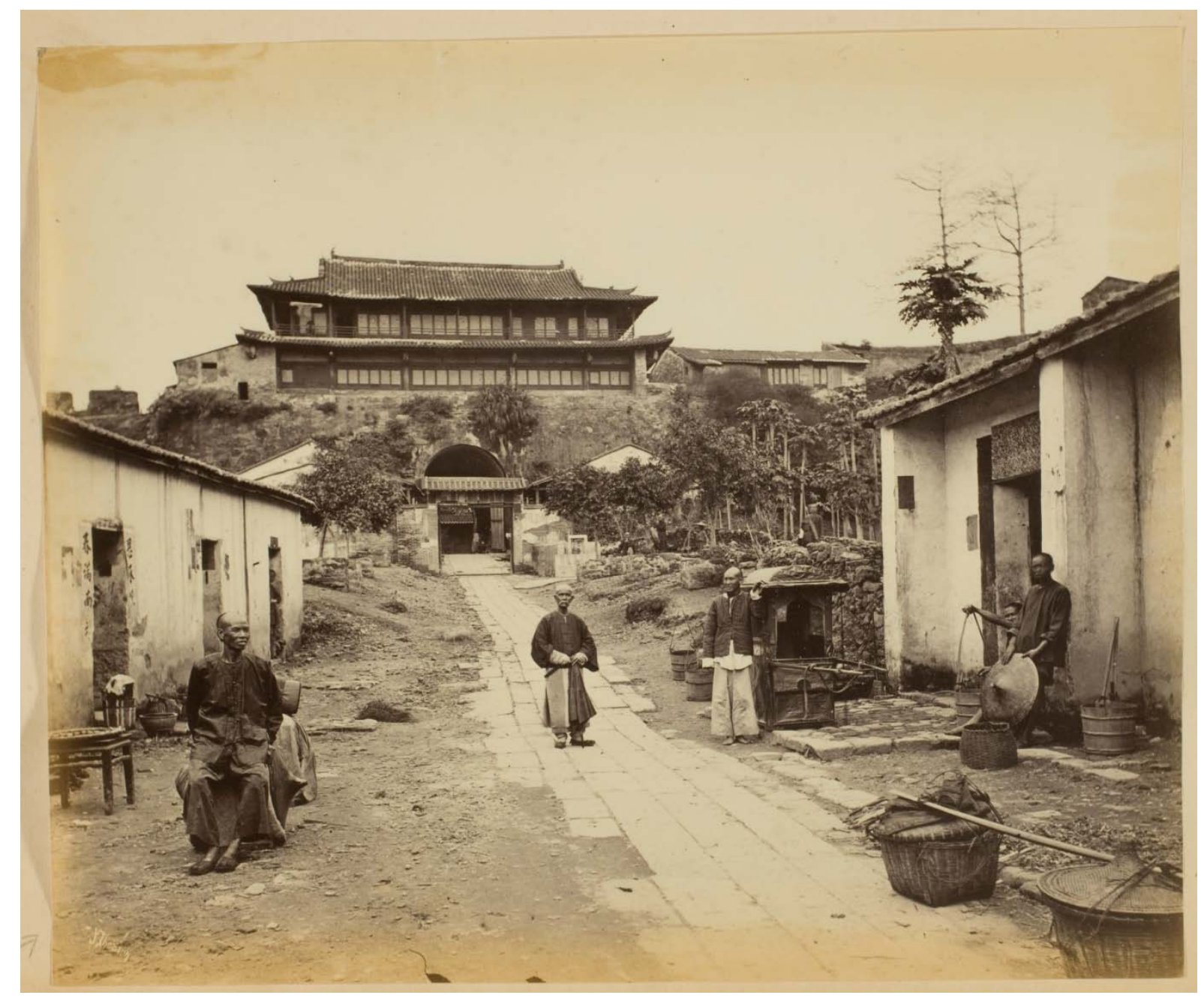

Accession No.: 1973:0219:0076

Page No.: 93

Date: $1862-1868$

Signature: Thomson’s signature at lower left

Dimensions: 22.7 x $27.1 \mathrm{~cm}$

Inscriptions: recto on album page (ink from $19^{\text {th }}$ century hand): West Gate / Canton recto on album page (pencil from Alden Scott Boyer hand): Photo Signed recto in print (white lettering, printed through from negative): J. Thomson verso on print (ink from $19^{\text {th }}$ century hand): West Gate Canton

References: Clark Worswick, Imperial China: Photographs 1850-1912, 102.

\section{Notes:}




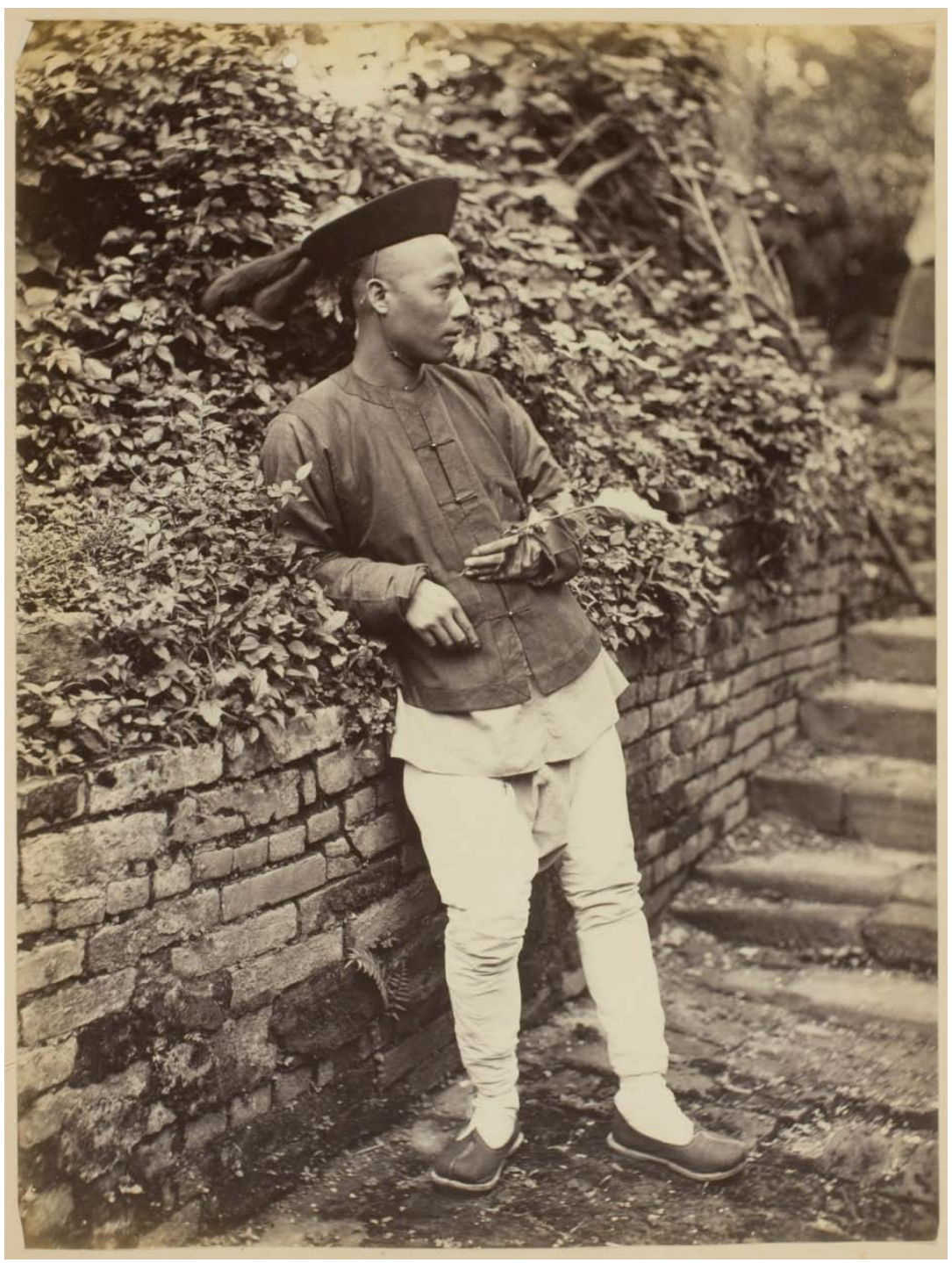

Accession No.: 1973:0219:0077

Page No.: 95

Date: $1862-1868$

Signature: no signature

Dimensions: 26.6 x $20 \mathrm{~cm}$

Inscriptions: recto on album page (ink from $19^{\text {th }}$ century hand): Tartar Canton recto on album page (pencil from Alden Scott Boyer hand): Tartar verso on print (ink from $19^{\text {th }}$ century hand): Canton

References: Wellcome Library Collection 19572i

http://search.wellcomelibrary.org/iii/encore/record/C_Rb1177450_S19572i

Orightresult____X3?lang=eng\&suite $=$ cobalt.

Notes: 


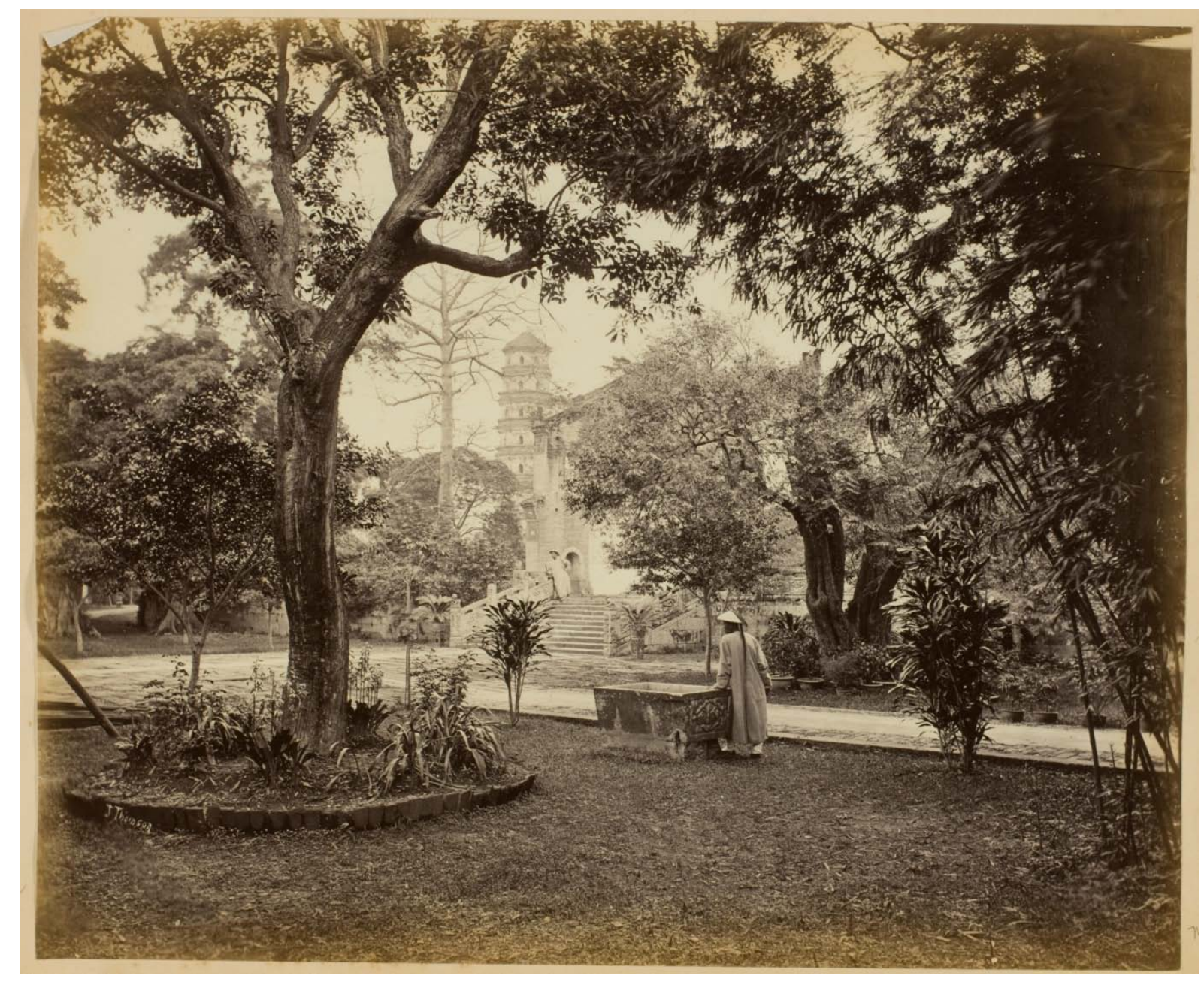

Accession No.: 1973:0219:0078

Page No.: 97

Date: $1862-1868$

Signature: Thomson's signature at lower left

Dimensions: 22.7 x $27.6 \mathrm{~cm}$

Inscriptions: recto on album page (ink from $19^{\text {th }}$ century hand): Consular / Garden / Canton recto on album page (pencil from Alden Scott Boyer hand): Signed Photo J. Thomson / Consular Garden recto in print (white lettering, printed through from negative): J. Thomson

References: John Thomson, Illustrations of China and Its People, Vol. I, Plate XVII, The British Consular Yamun, Canton.

\section{Notes:}




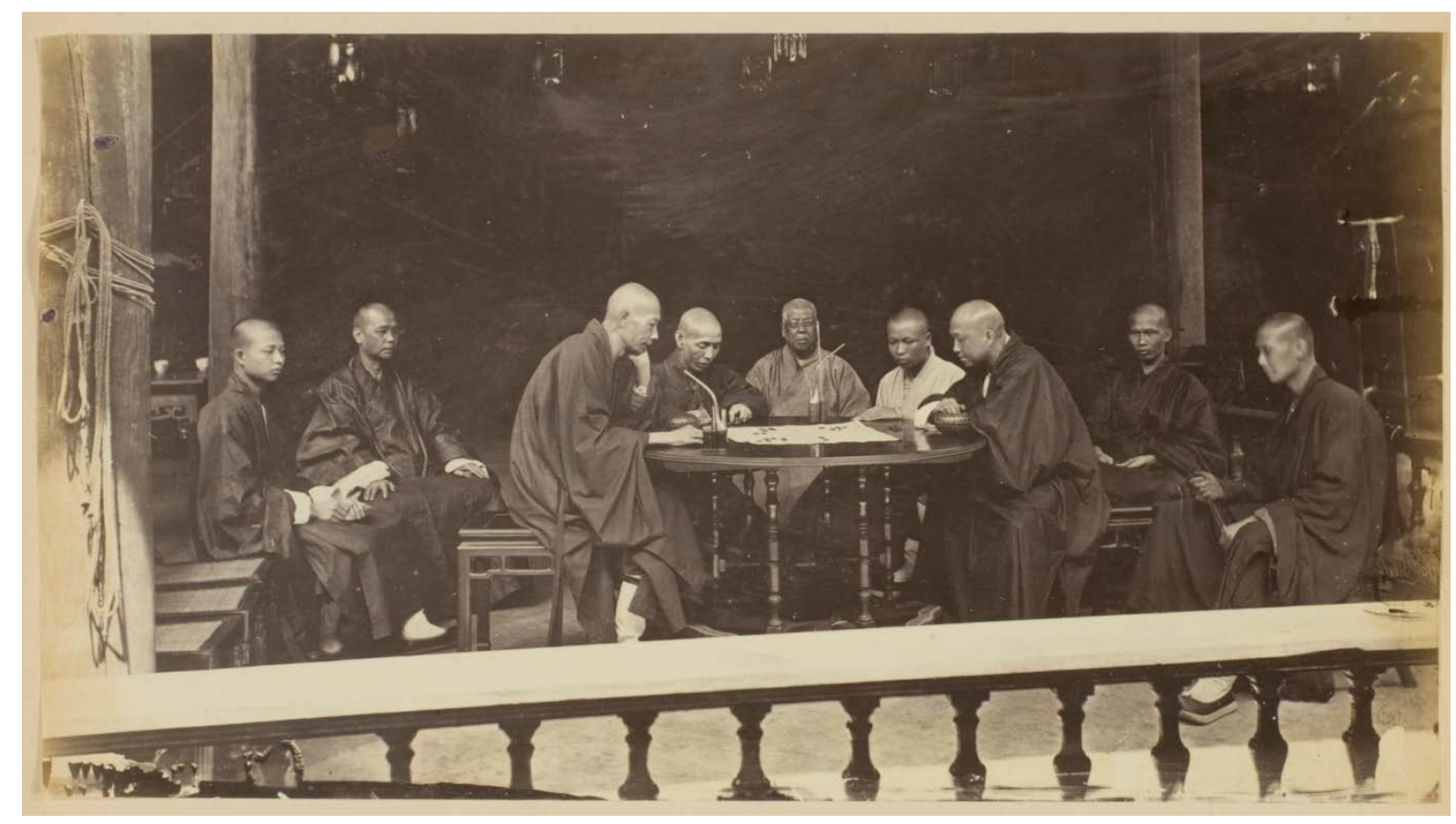

Accession No.: 1973:0219:0079

Page No.: 99

Date: $1862-1868$

Signature: no signature

Dimensions: 15.1 x $27.6 \mathrm{~cm}$

Inscriptions: recto on album page (ink from $19^{\text {th }}$ century hand): Monks playing recto on album page (pencil from Alden Scott Boyer hand): Monks verso on print (ink from $19^{\text {th }}$ century hand): A favorite [illegible] of monks

References: Wellcome Library Collection 19530i http://search.wellcomelibrary.org/iii/encore/record/C_Rb1177408_S19530i Orightresult_U_X3?lang=eng\&suite $=$ cobalt.

John Thomson, The Straits of Malacca, Indo-China, and China, 266, Chess-playing in a Buddhist Monastery.

Notes: 


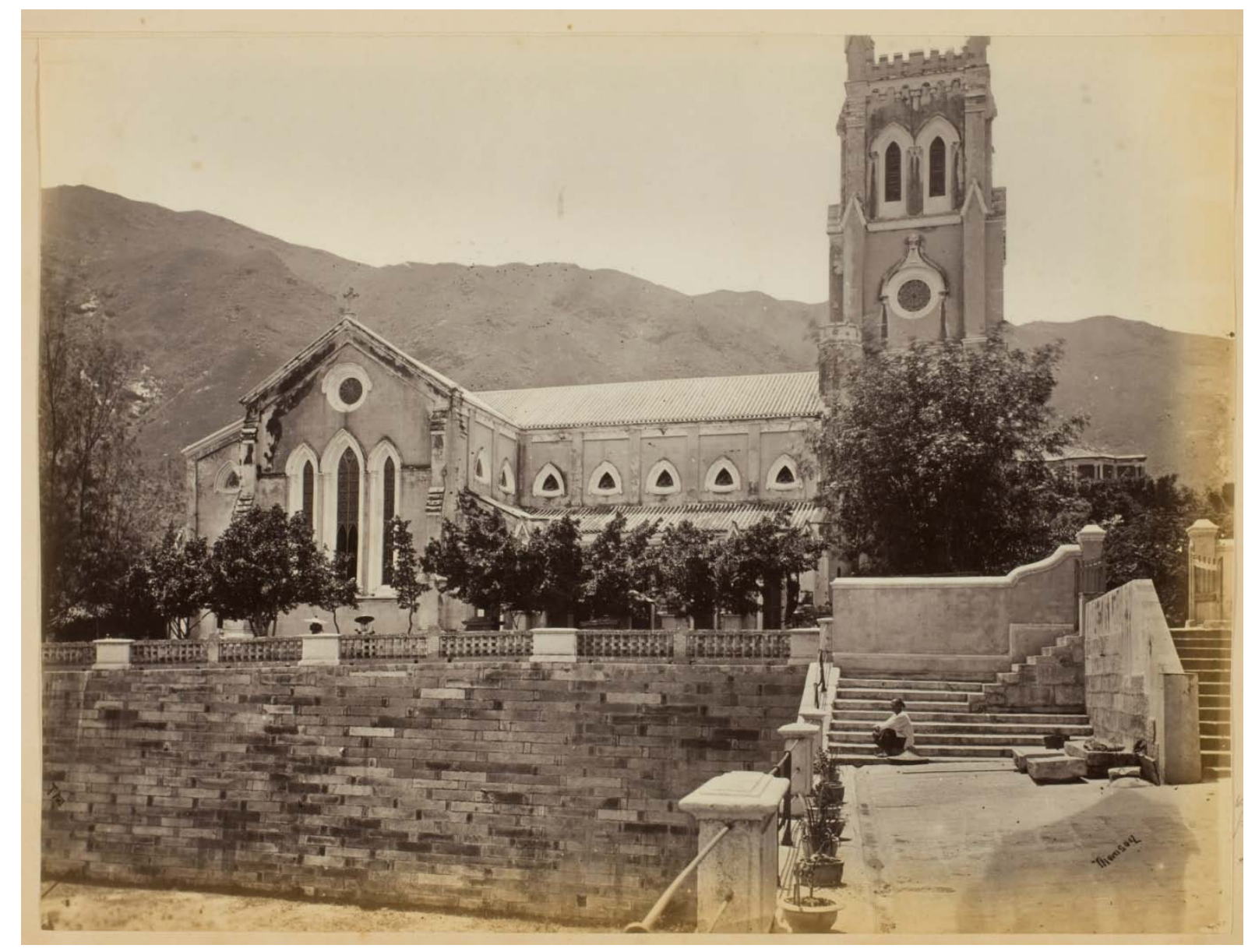

Accession No.: 1973:0219:0082

Page No.: 103

Date: $1862-1868$

Signature: Thomson's signature at lower right

Dimensions: 23.3 x $27.6 \mathrm{~cm}$

Inscriptions: recto on album page (ink from $19^{\text {th }}$ century hand): St John's Cathedral / Hong Kong recto on album page (pencil from Alden Scott Boyer hand): Signed Photo THOMSON recto in print (black lettering, printed through from negative): Thomson recto on print (ink from $19^{\text {th }}$ century hand): St John's Cathedral / HK

References: Roberta Wue, Picturing Hong Kong: Photography 1855-1910, 69.

Notes: St. John's Cathedral, officially The Cathedral Church of St. John the Evangelist, which is located at 4 Garden Road, was opened to the public in $1849 .{ }^{125}$

125 “A Brief History of St John's Cathedral,” accessed May 23, 2014, http://www.stjohnscathedral.org.hk/Page.aspx?lang=1\&id=97. 


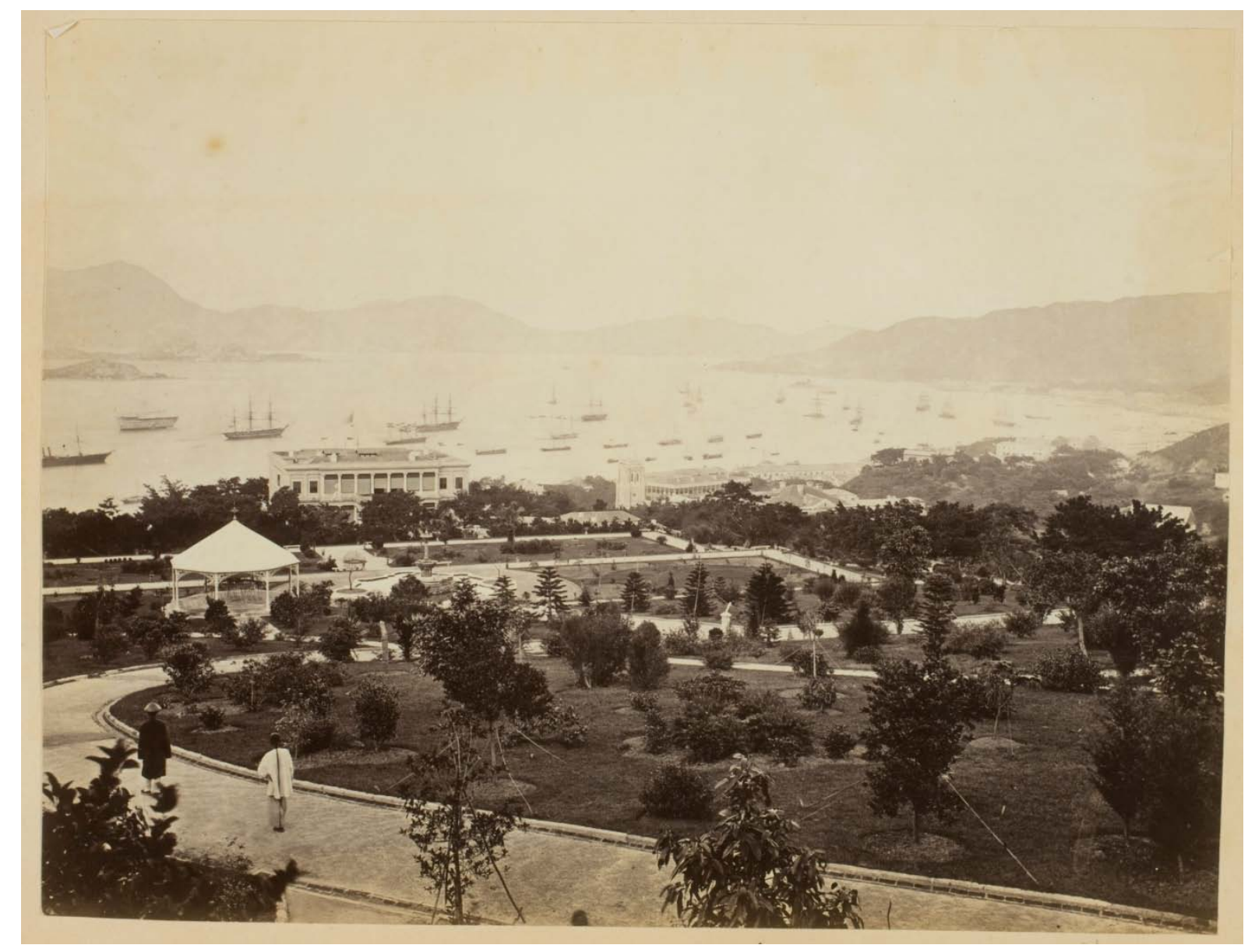

Accession No.: 1973:0219:0085

Page No.: 105

Date: $1862-1868$

Signature: no signature

Dimensions: 19.1 x $25.2 \mathrm{~cm}$

Inscriptions: recto on album page (ink from $19^{\text {th }}$ century hand): Botanical Gardens Hong Kong recto on album page (pencil from Alden Scott Boyer hand): Harbor of Hong Kong / B verso on print (ink from $19^{\text {th }}$ century hand): Botanical Garden

References: Wellcome Library Collection 18674i

http://search.wellcomelibrary.org/iii/encore/record/C_Rb1176552_S18674i Orightresult__U_X3?lang $=$ eng\&suite $=$ cobalt.

Notes: The Hong Kong Zoological and Botanical Gardens is one of the oldest zoological and botanical gardens in the world. It opened to the public in $1864 .{ }^{126}$

126 “Hong Kong Zoological and Botanical Gardens,” accessed May 23, 2014, http://www.lcsd.gov.hk/parks/hkzbg/en/index.php. 


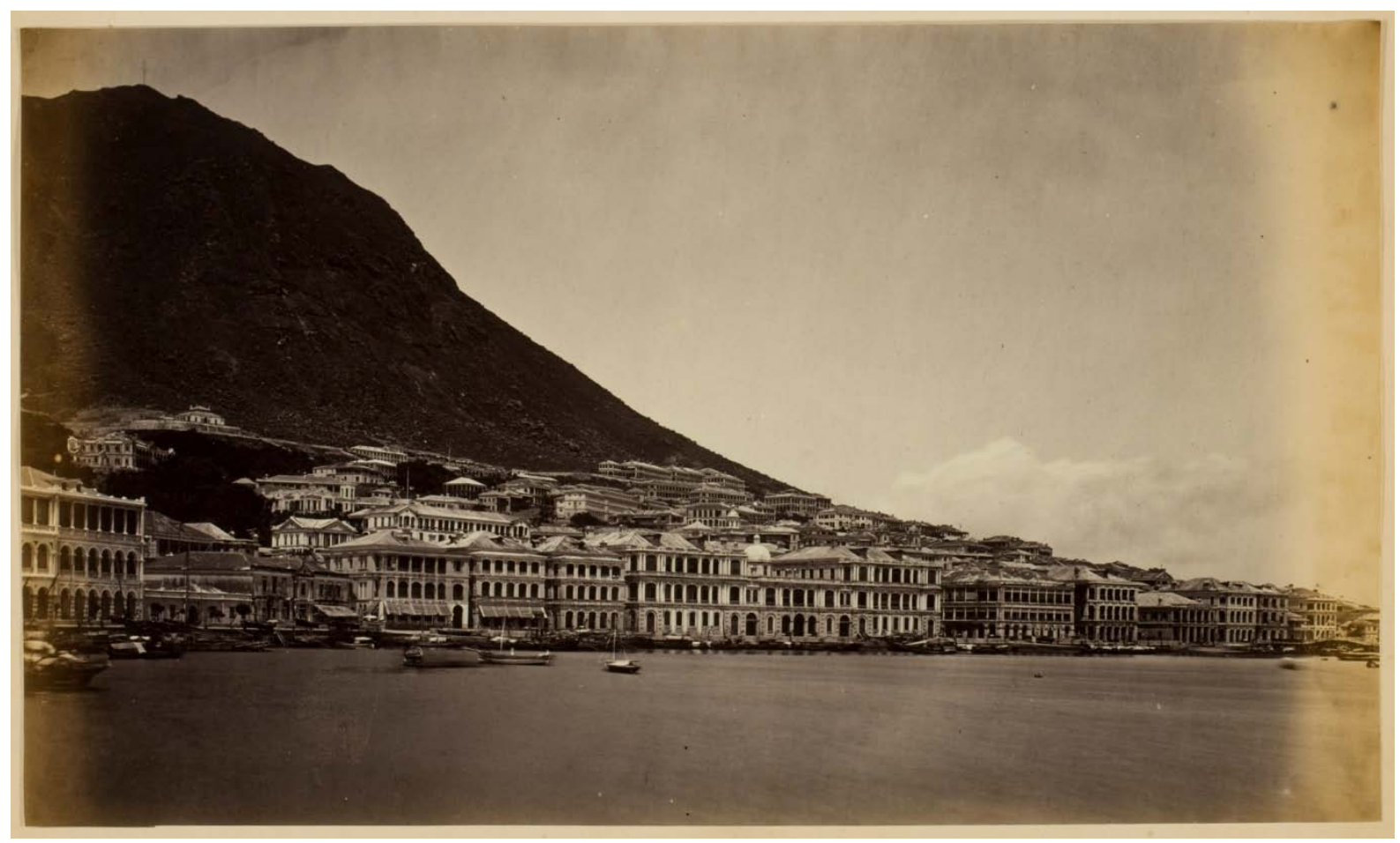

Accession No.: 1973:0219:0088

Page No.: 109

Date: $1862-1868$

Signature: no signature

Dimensions: 17.8 x $29.9 \mathrm{~cm}$

Inscriptions: recto on album page (ink from $19^{\text {th }}$ century hand): cms / Hong Kong recto on album page (pencil from Alden Scott Boyer hand): Fine. B verso on print (ink from $19^{\text {th }}$ century hand): View Through the Praya / HK

References: John Thomson, Illustrations of China and Its People, Vol. I, Plate VI, The Praya, Hong-Kong.

Notes: 


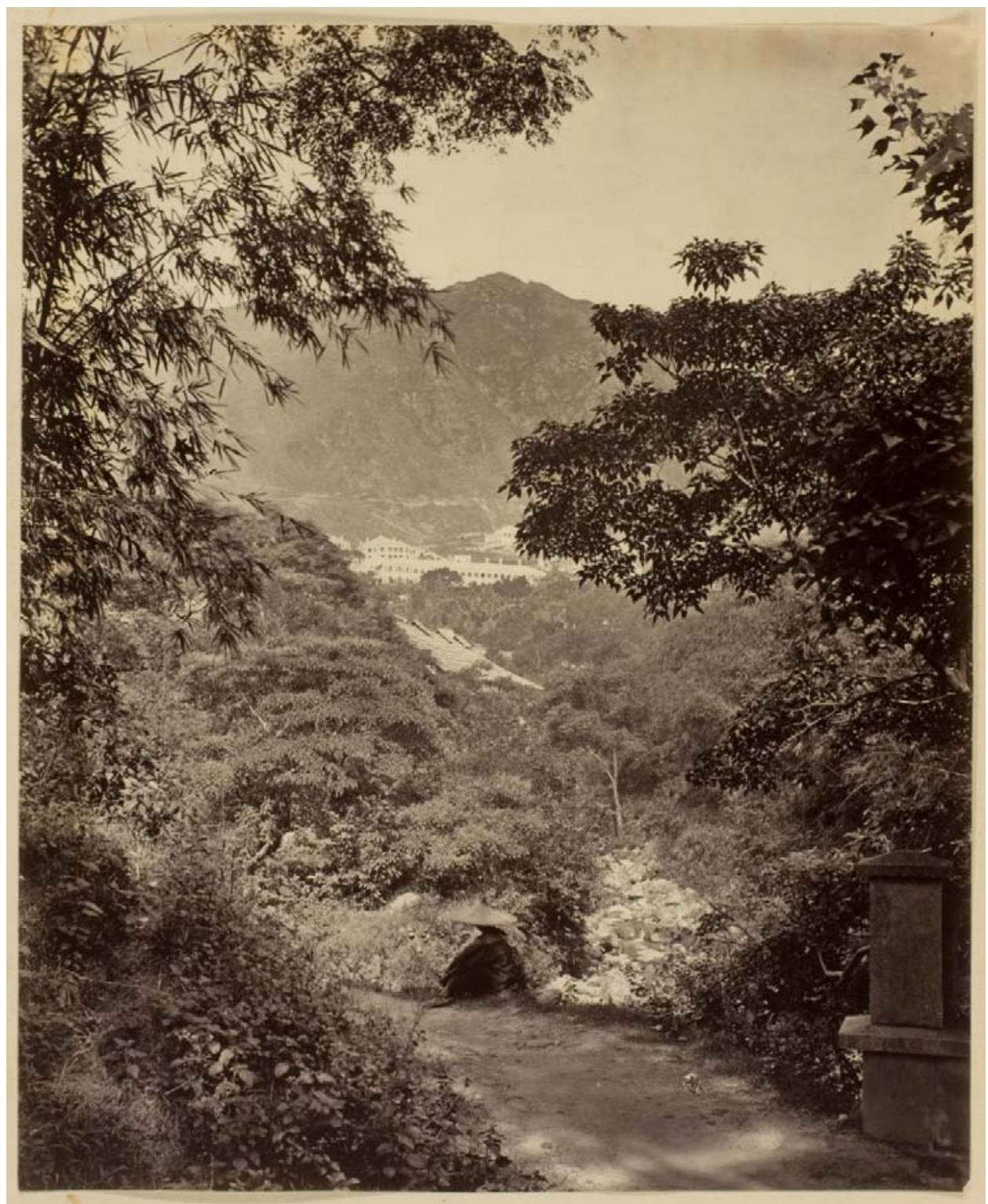

Accession No.: 1973:0219:0089

Page No.: 111

Date: $1862-1868$

Signature: no signature

Dimensions: 22.1 x $17.9 \mathrm{~cm}$

Inscriptions: recto on album page (ink from $19^{\text {th }}$ century hand): The Albany / Hong Kong

References: Wellcome Library Collection 18698i

http://search.wellcomelibrary.org/iii/encore/record/C_Rb1176576_S18698i

Orightresult__X3?lang $=$ eng\&suite $=$ cobalt.

Notes: 


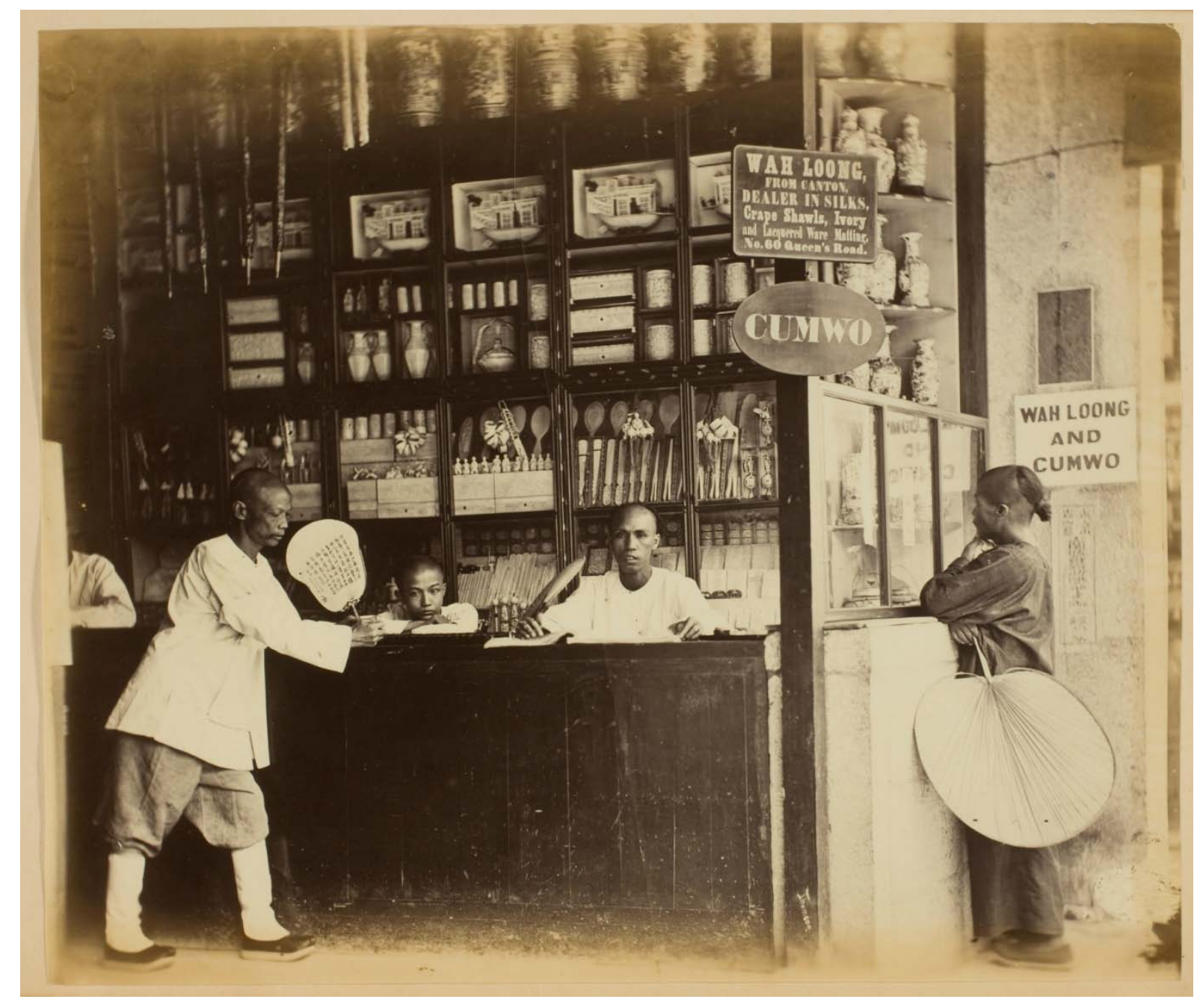

Accession No.: 1973:0219:0090

Page No.: 113

Date: $1862-1868$

Signature: Thomson's signature at lower centre

Dimensions: 23.2 x $27.6 \mathrm{~cm}$

Inscriptions: recto on album page (ink from $19^{\text {th }}$ century hand): Hong Kong recto on album page (pencil from Alden Scott Boyer hand): China / Store recto in print (white lettering, printed through from negative): Thomson verso on print (ink from $19^{\text {th }}$ century hand): Burn Shoh

References: Wellcome Library Collection 19974i

http://search.wellcomelibrary.org/iii/encore/record/C_Rb1177852_S19974i

Orightresult__U_X3?lang $=$ eng\&suite $=$ cobalt.

Notes: Shop of Wah Loong and Cumwo 


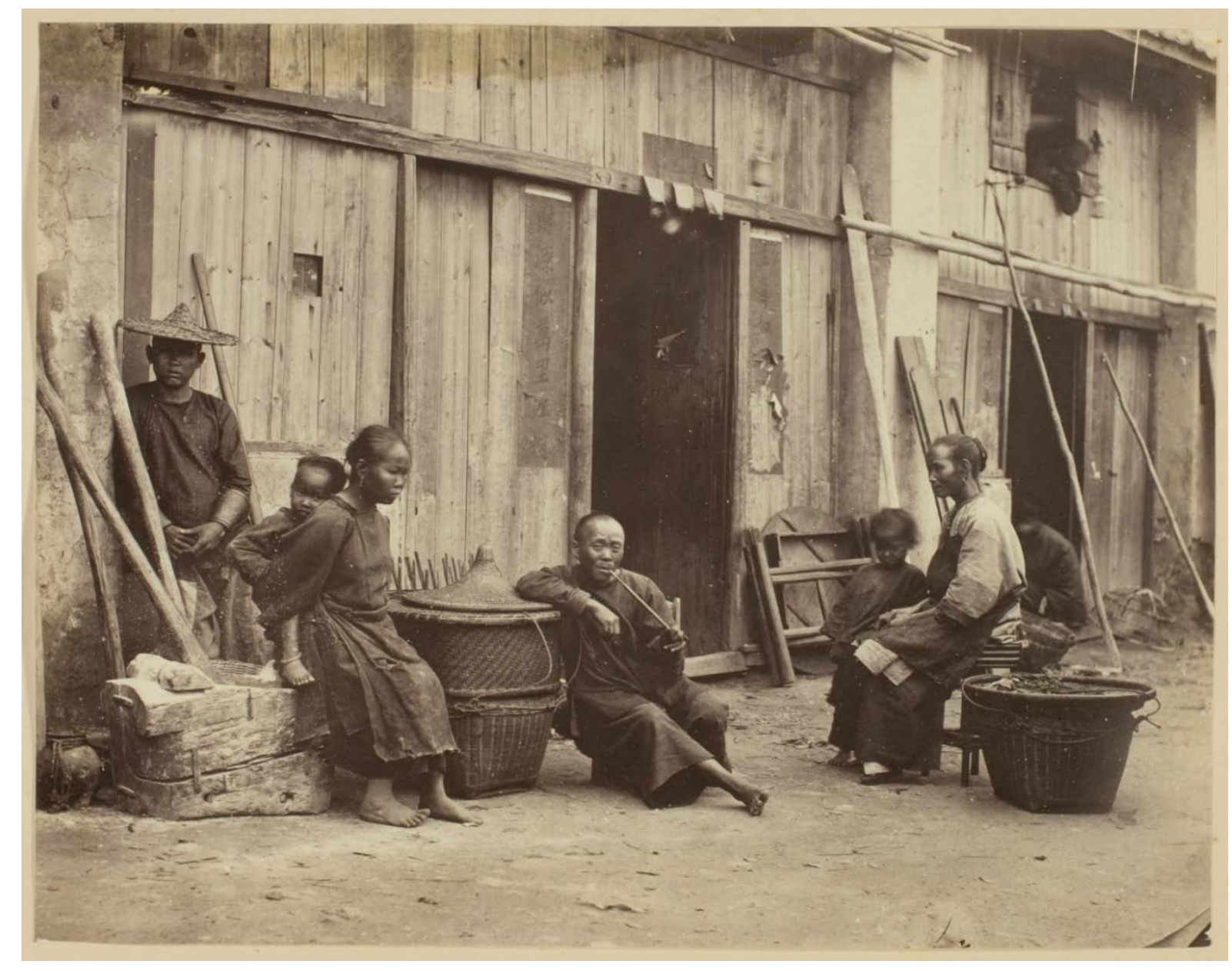

Accession No.: 1973:0219:0091

Page No.: 115

Date: $1862-1868$

Signature: no signature

Dimensions: 17 x $22 \mathrm{~cm}$

Inscriptions: recto on album page (ink from $19^{\text {th }}$ century hand): Canton verso on print (ink from $19^{\text {th }}$ century hand): Villages

References: Stephen White, John Thomson: A Window to the Orient, Plate 75.

Notes: White alone has attributed this image to Thomson, and it is not included in the surviving negatives at the Welcome Library, nor appeared in any of Thomson's publications, nor does it exist as a print in any known public collection. 


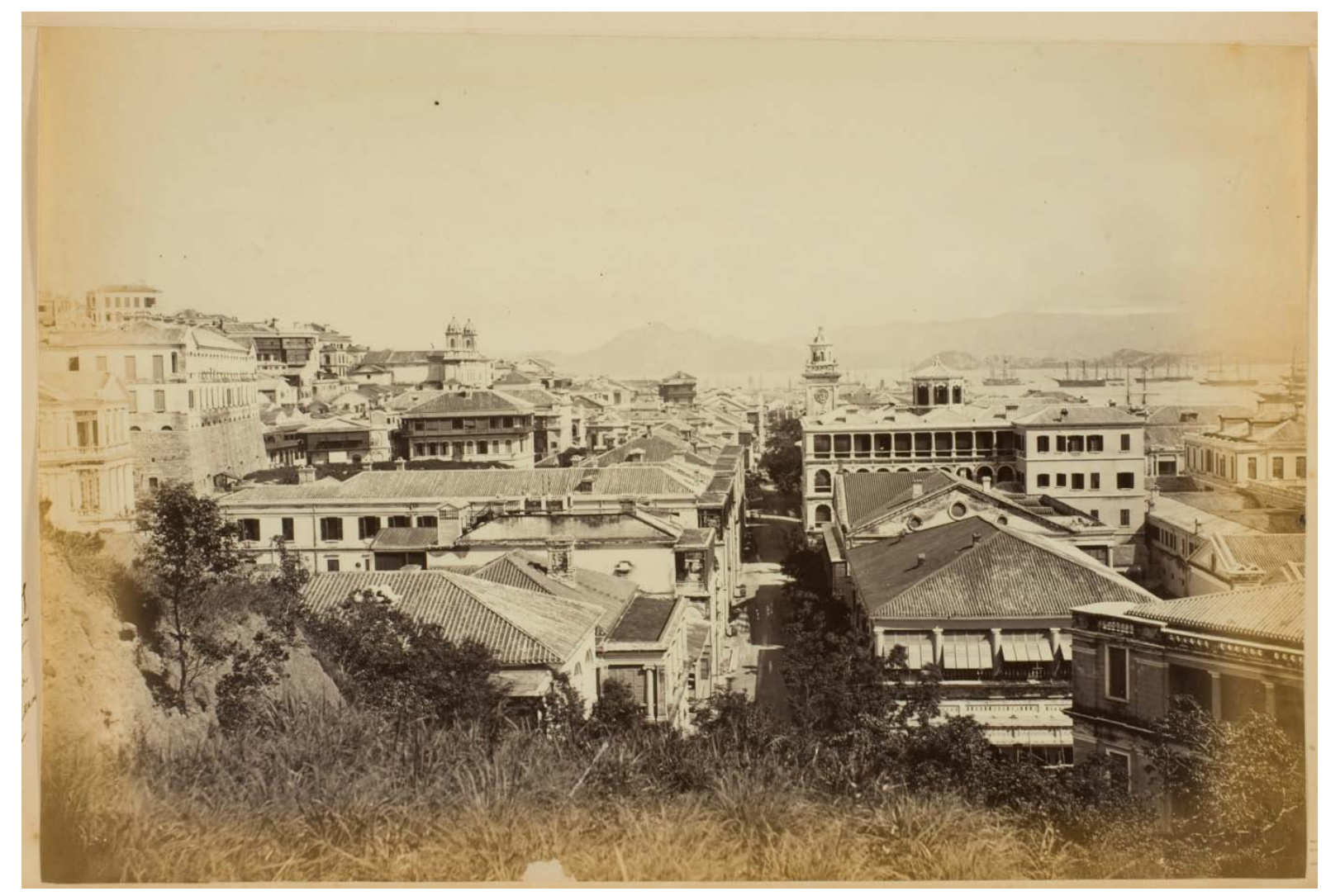

Accession No.: 1973:0219:0092

Page No.: 117

Date: $1862-1868$

Signature: no signature

Dimensions: 23.4 x $31 \mathrm{~cm}$

Inscriptions: recto on album page (ink from $19^{\text {th }}$ century hand): Hong / Kong/ Govet / office / Garden verso on print (ink from $19^{\text {th }}$ century hand): Government Office Garden

References: Wellcome Library Collection 18722i http://search.wellcomelibrary.org/iii/encore/record/C_Rb1176600_S18722i Orightresult__U_X3?lang $=$ eng\&suite $=$ cobalt.

\section{Notes:}




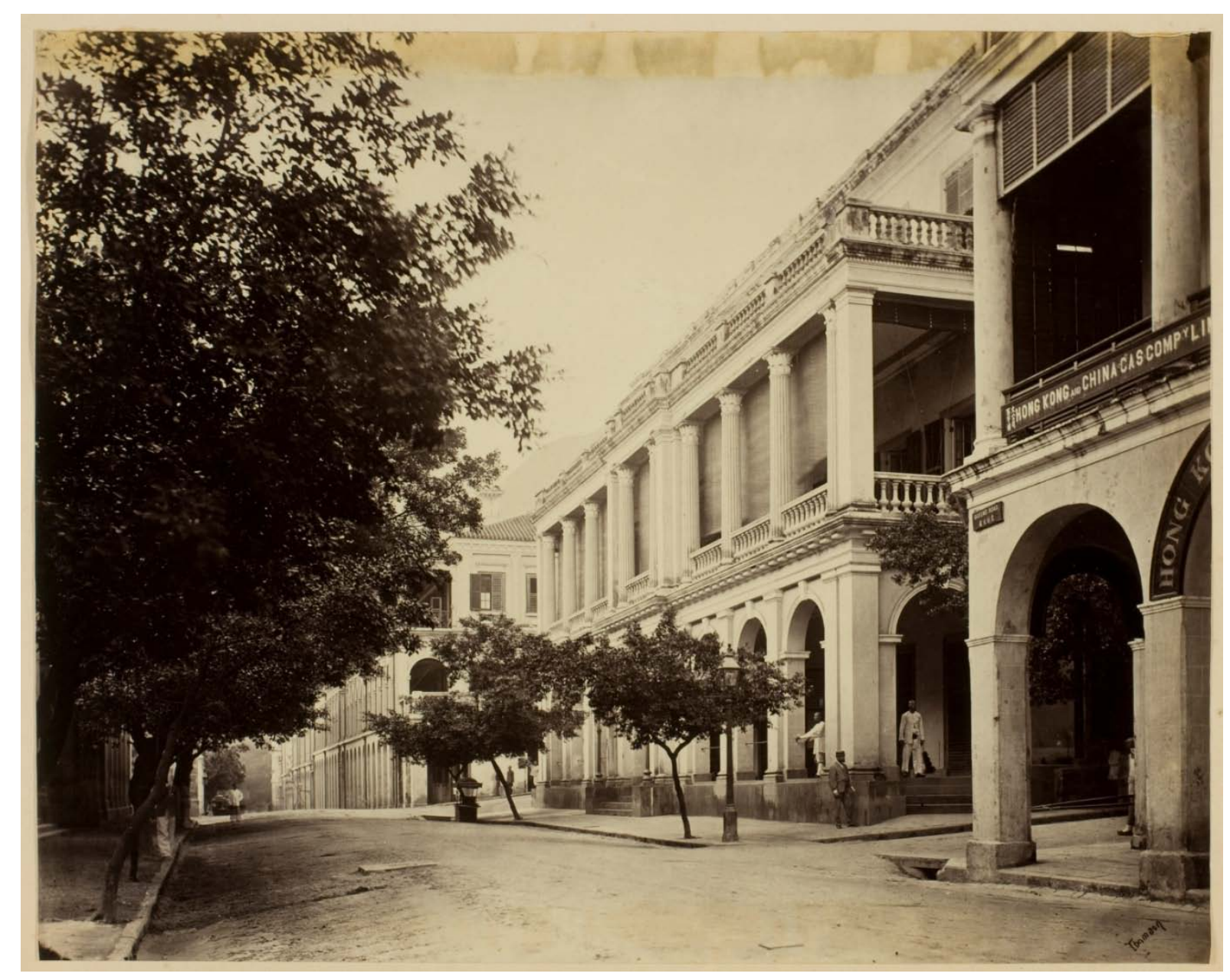

Accession No.: 1973:0219:0093

Page No.: 119

Date: $1862-1868$

Signature: Thomson's signature at lower right

Dimensions: 18.4 x $23.3 \mathrm{~cm}$

Inscriptions: recto on album page (ink from $19^{\text {th }}$ century hand): The Club Hong Kong recto in print (black lettering, printed through from negative): Thomson verso on print (ink from $19^{\text {th }}$ century hand): H Kong Club / HK

\section{References:}

Notes: The Hong Kong Club was the first private Gentlemen's club in Hong Kong. Opened in 1846, it was located at Central, Hong Kong. ${ }^{127}$

\footnotetext{
127 Wikipedia, “Hong Kong Club,” last modified on 30 October 2013, accessed July 11, 2014,
} http://en.wikipedia.org/wiki/Hong_Kong_Club. 


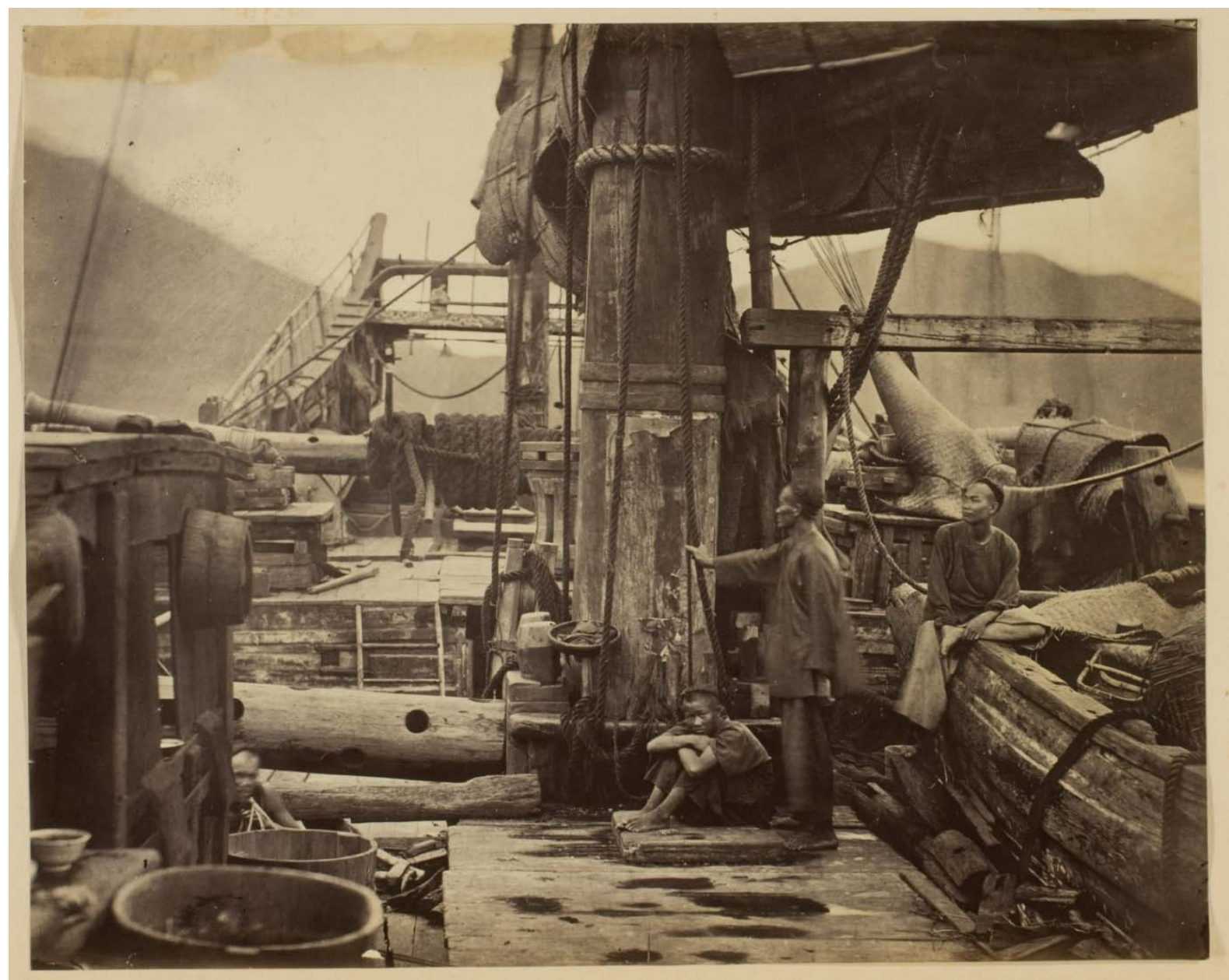

Accession No.: 1973:0219:0094

Page No.: 121

Date: $1862-1868$

Signature: no signature

Dimensions: 17.8 x $22.3 \mathrm{~cm}$

Inscriptions: recto on album page (ink from $19^{\text {th }}$ century hand): Chinese Junk recto on album page (pencil from Alden Scott Boyer hand): Note Gun / aboard a Chinese Junk verso on print (ink from $19^{\text {th }}$ century hand): Chinese Junk

References: John Thomson, The Straits of Malacca, Indo-China, and China, 270, Deck of A Chinese Junk.

\section{Notes:}




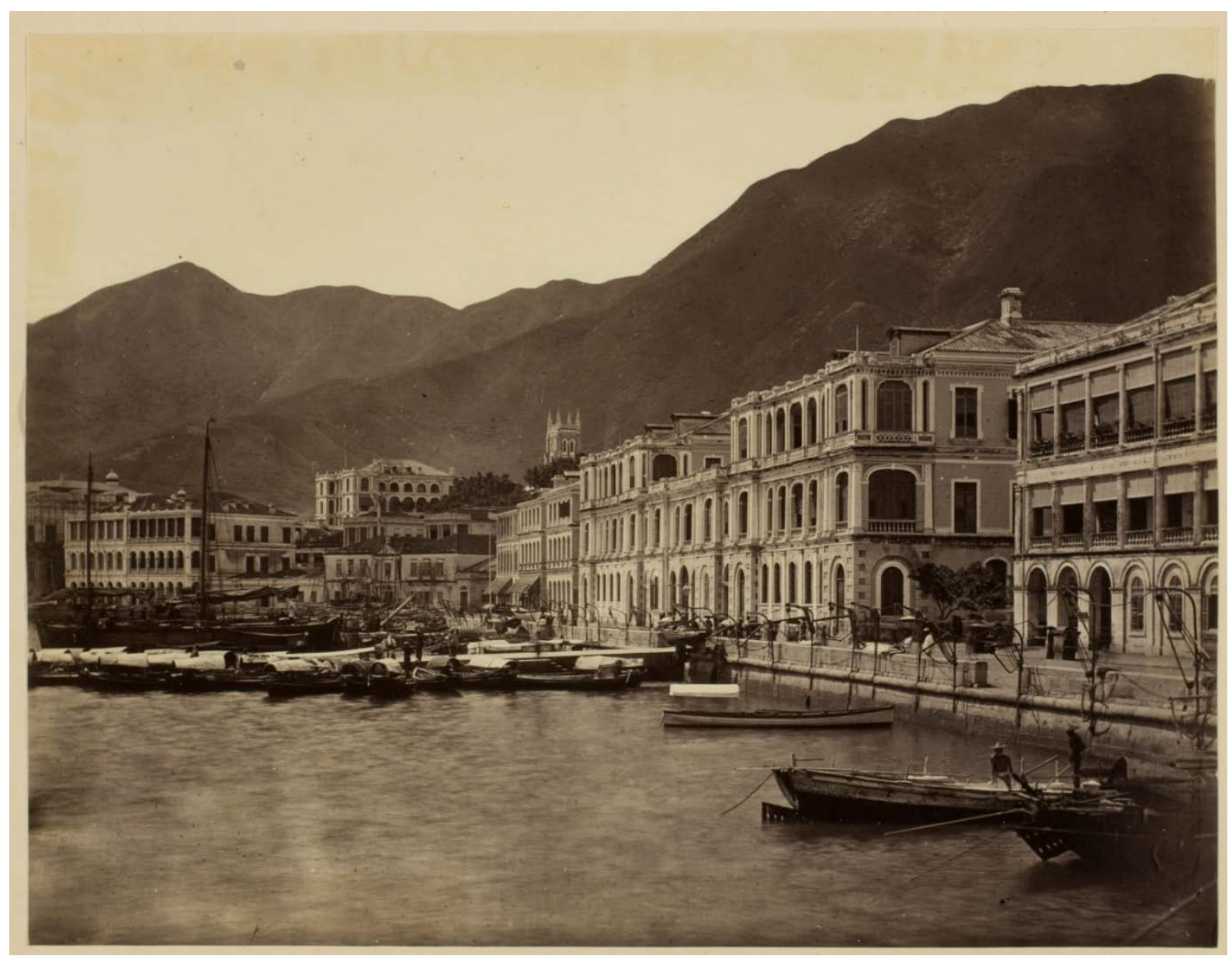

Accession No.: 1973:0219:0095

Page No.: 123

Date: $1862-1868$

Signature: no signature

Dimensions: 17.7 x $23.2 \mathrm{~cm}$

Inscriptions: recto on album page (ink from $19^{\text {th }}$ century hand): Hong Kong / Pedders Wharf verso on print (ink from $19^{\text {th }}$ century hand): May $2 \mathrm{HK}$

References: Wellcome Library Collection 18692i

http://search.wellcomelibrary.org/iii/encore/record/C_Rb1176570_SHong\%20 Kong\%20Bund_Orightresult_U_X3?lang=eng\&suite $=$ cobalt.

Notes: Pedder Wharf (1841-1890) served as the official wharf from 1841 well into the 1890s. After the Praya Reclamation Scheme, Pedder Wharf was replaced by Blake Pier. $^{128}$

\footnotetext{
${ }^{128}$ Eric Cavaliero, “Pedder Street Was Where It all Happened,” August 13, 1998, accessed May 23, 2014, http://www.thestandard.com.hk/news_detail.asp?pp_cat=\&art_id=40111\&sid=\&con_type=1\&d_str=19980813\& sear_year=1998.
} 


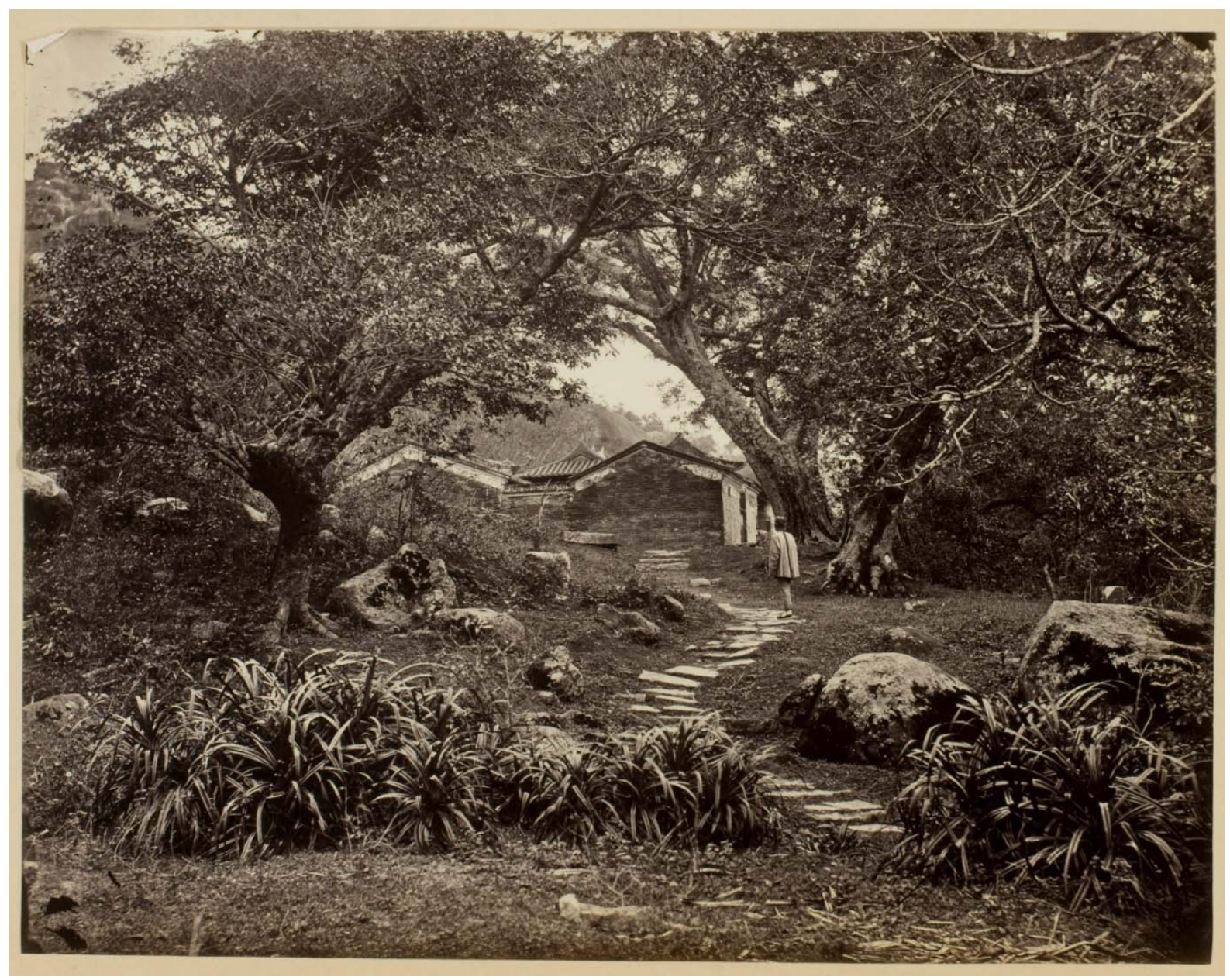

Accession No.: 1973:0219:0097

Page No.: 127

Date: $1862-1868$

Signature: no signature

Dimensions: 18.1 x $23.2 \mathrm{~cm}$

Inscriptions: recto on album page (ink from $19^{\text {th }}$ century hand): Joss House East Point

References: Wellcome Library Collection 18886i

http://search.wellcomelibrary.org/iii/encore/record/C_Rb1176764_S18886i Orightresult__U_XX? lang $=$ eng\&suite $=$ cobalt.

Notes: 


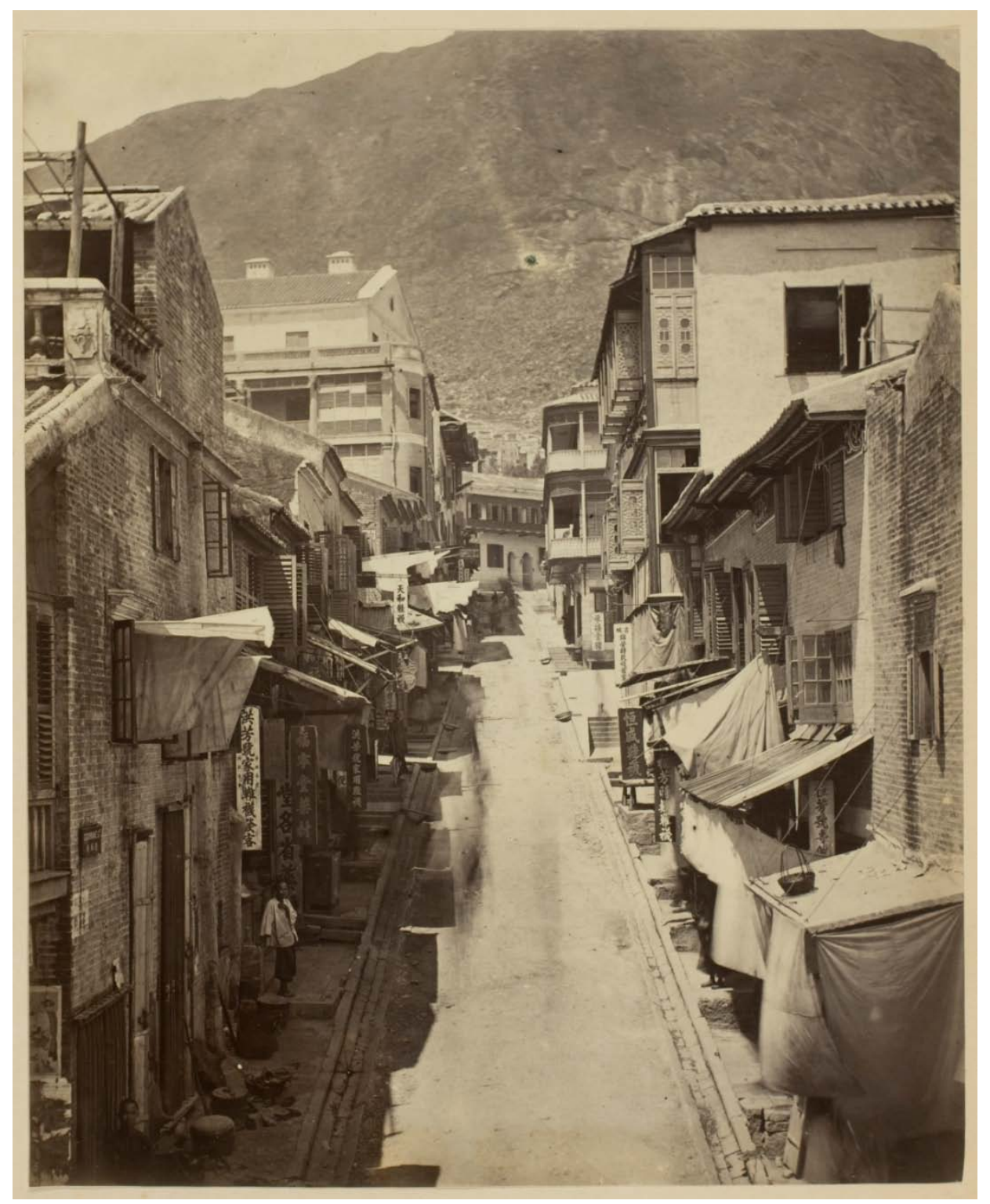

Accession No.: 1973:0219:0100

Page No.: 131

Date: $1862-1868$

Signature: no signature

Dimensions: 22.1 x $17.9 \mathrm{~cm}$

Inscriptions: recto on album page (ink from $19^{\text {th }}$ century hand): Cochrane Street / H Kong verso on print (ink from $19^{\text {th }}$ century hand): Cochrane Street / HK

References: Wellcome Library Collection 18696i http://search.wellcomelibrary.org/iii/encore/record/C_Rb1176574_S18696i Orightresult_U_X

Notes: 


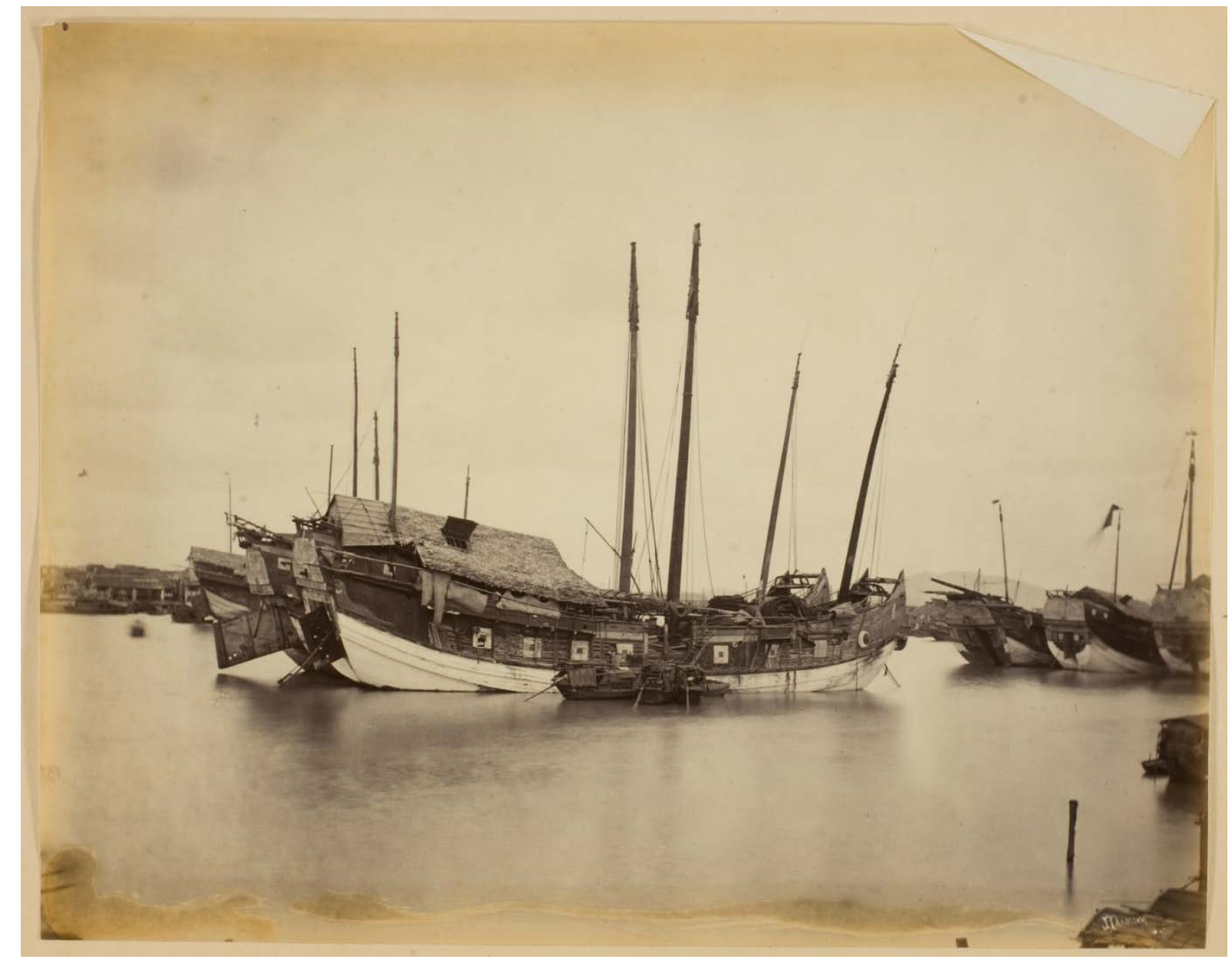

Accession No.: 1973:0219:0101

Page No.: 133

Date: $1862-1868$

Signature: Thomson's signature at lower right

Dimensions: 21.1 x $27 \mathrm{~cm}$

Inscriptions: recto on album page (ink from $19^{\text {th }}$ century hand): Junks / H Kong recto on album page (pencil from Alden Scott Boyer hand): JUNKS at Hong Kong / note sterns recto in print (white lettering, printed through from negative): J. Thomson

References: John Thomson, Illustrations of China and Its People, Vol. II, Plate XIX, Old Junks.

Notes: According to Thomson's book cited above, this photo was taken at Canton River (Pearl River). 


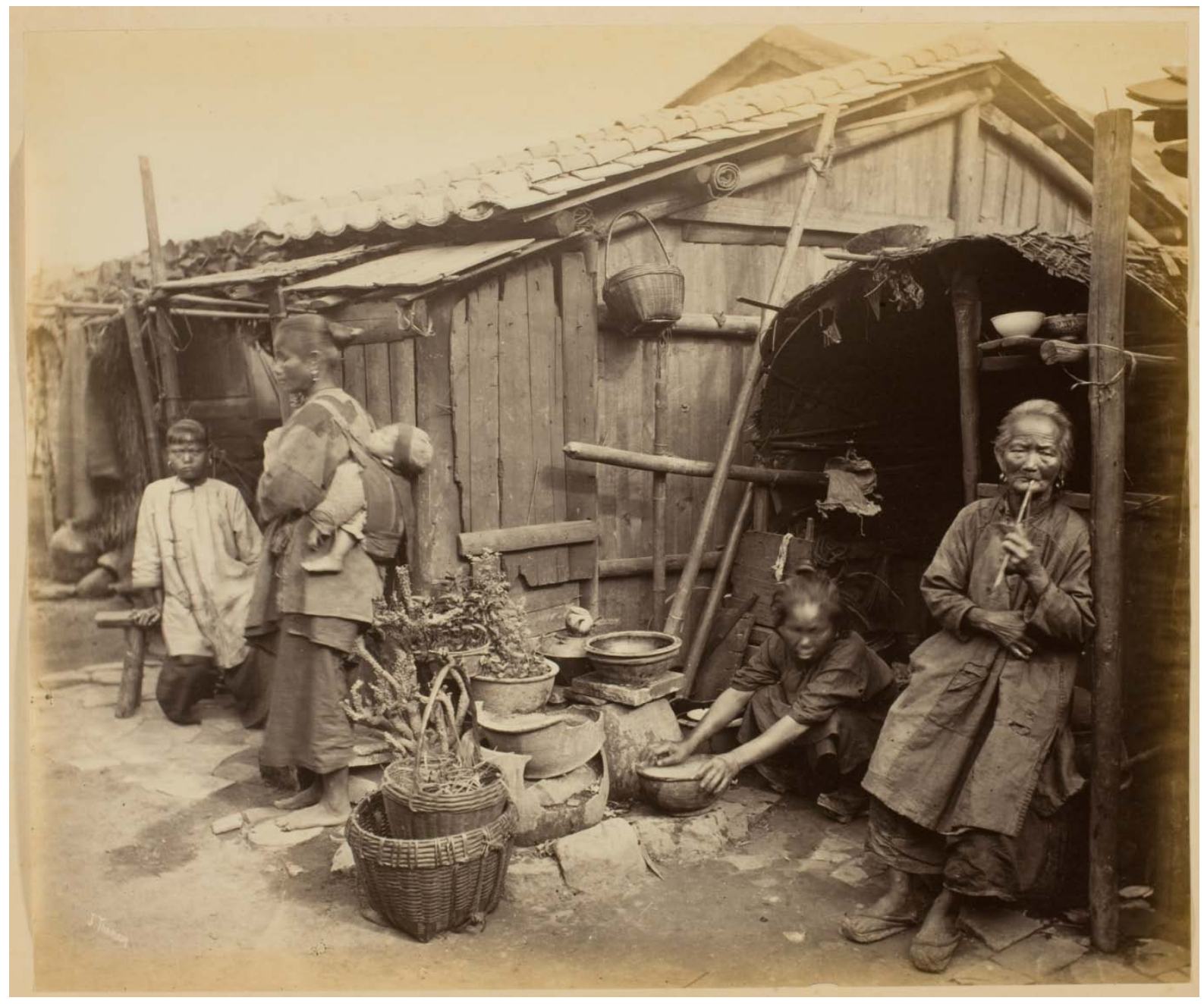

Accession No.: 1973:0219:0103

Page No.: 137

Date: $1862-1868$

Signature: Thomson's signature at lower left

Dimensions: 22.3 x $27 \mathrm{~cm}$

Inscriptions: recto in print (white lettering, printed through from negative): J. Thomson

References: John Thomson, Through China with a Camera, 59, Suburban Residents, Canton.

Notes: 


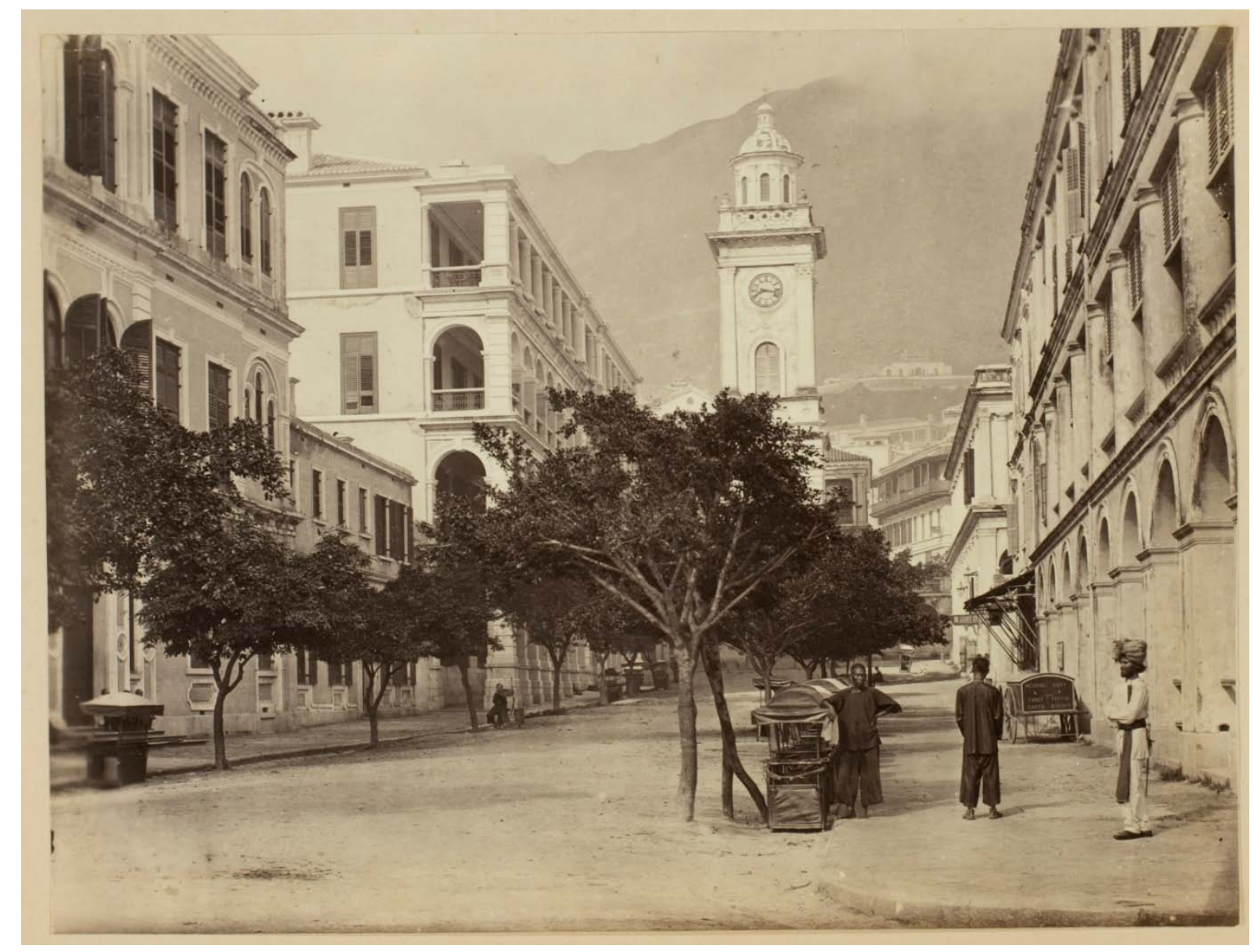

Accession No.: 1973:0219:0104

Page No.: 139

Date: $1862-1868$

Signature: no signature

Dimensions: 16.7 x $23 \mathrm{~cm}$

Inscriptions: recto on album page (ink from $19^{\text {th }}$ century hand): From / Pedders Wharf / $\mathrm{H}$ Kong verso on print (ink from $19^{\text {th }}$ century hand): Clock Tower / HK

References: Wellcome Library Collection 18700i http://search.wellcomelibrary.org/iii/encore/record/C_Rb1176578_S18700i Orightresult__U_X3?lang $=$ eng\&suite $=$ cobalt.

John Thomson, Illustrations of China and Its People, Vol. I, Plate V, The Clock-Tower, Hong-Kong.

Notes: 


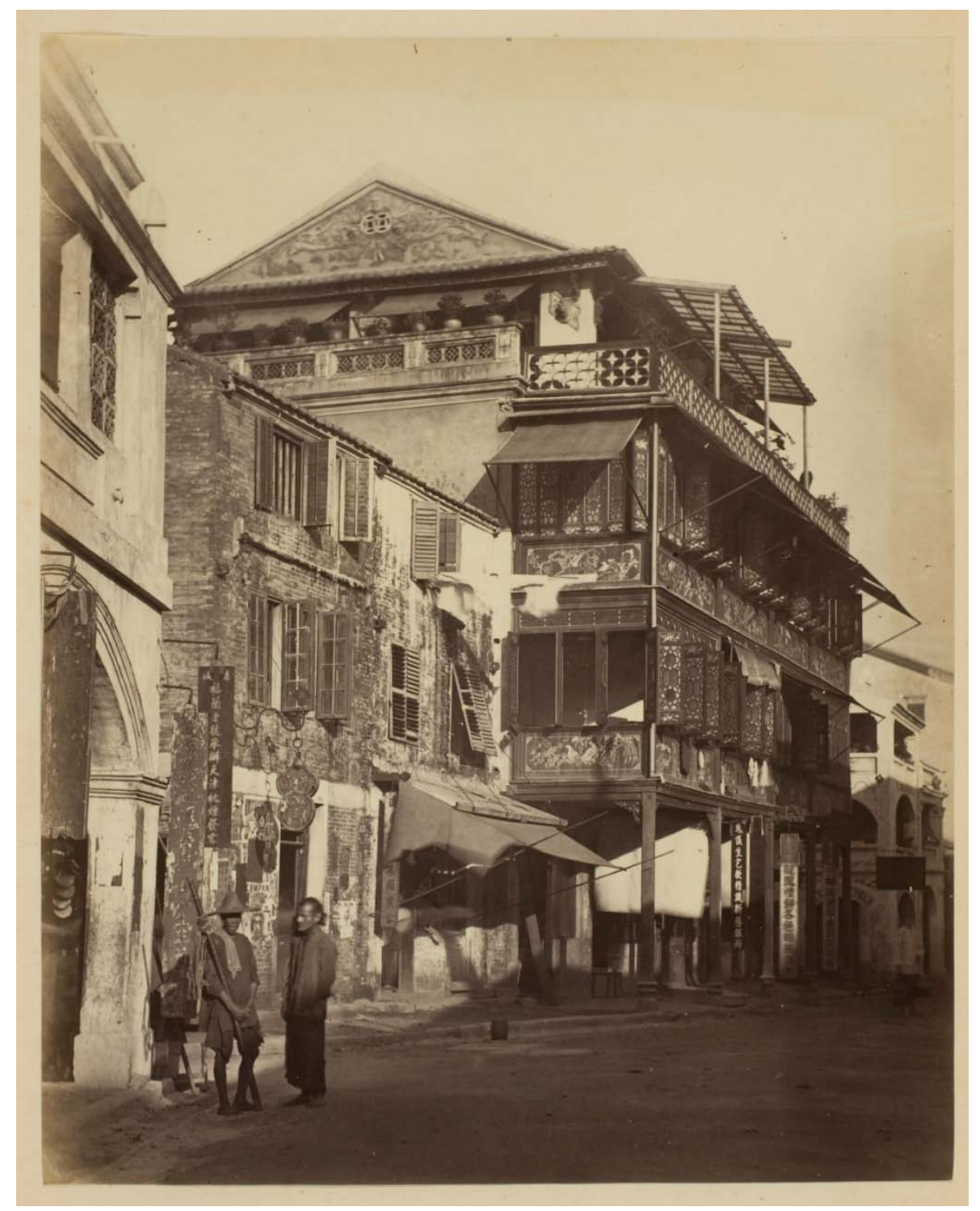

Accession No.: 1973:0219:0105

Page No.: 141

Date: $1862-1868$

Signature: no signature

Dimensions: 22.9 x $18.2 \mathrm{~cm}$

Inscriptions: recto on album page (ink from $19^{\text {th }}$ century hand): Hong Kong / Chinese / Entry House verso on print (ink from $19^{\text {th }}$ century hand): China Hotel

References: Wellcome Library Collection 19990i http://search.wellcomelibrary.org/iii/encore/record/C_Rb1177868_S19990i Orightresult_U_X3?lang=eng\&suite $=$ cobalt.

\section{Notes:}




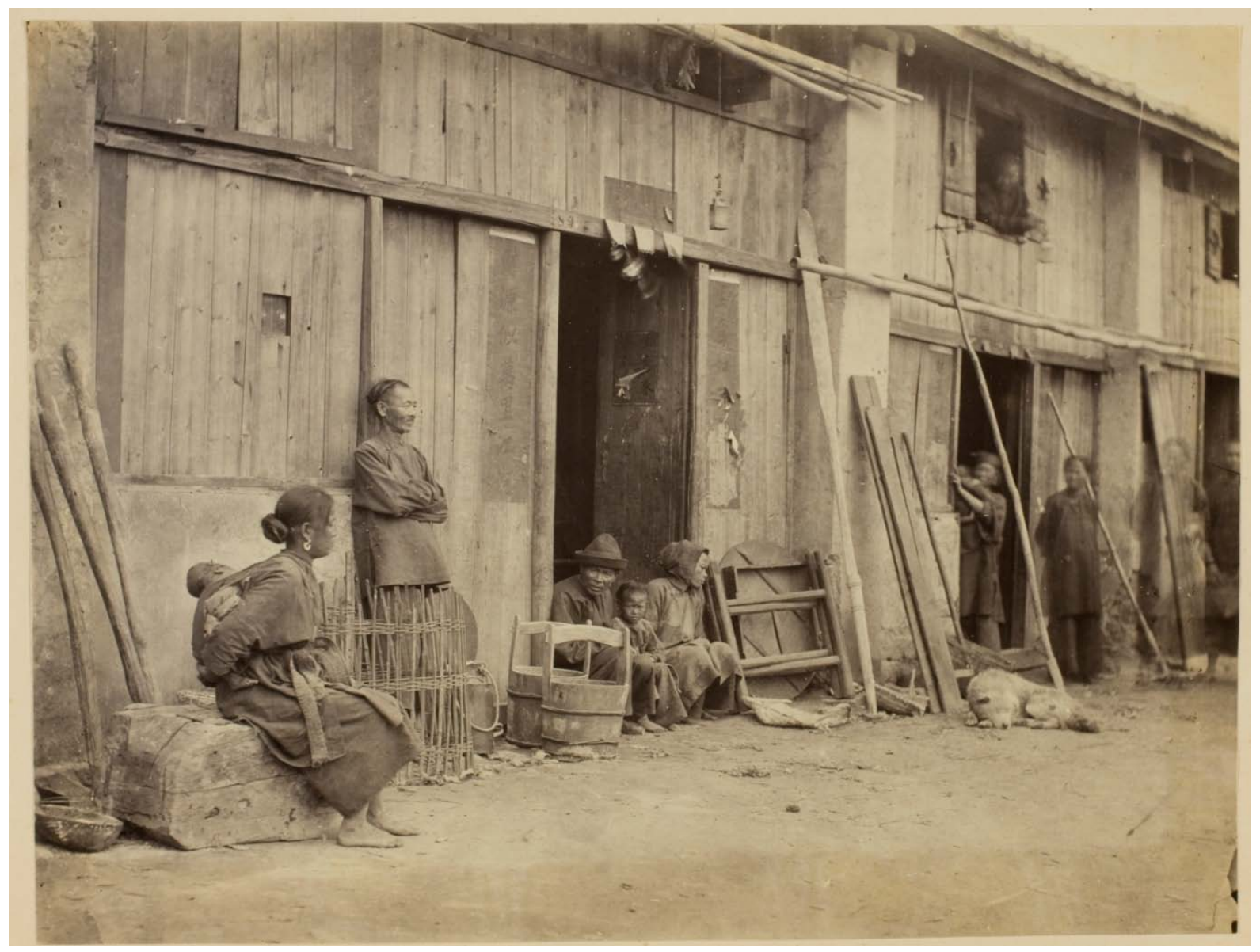

Accession No.: 1973:0219:0106

Page No.: 143

Date: $1862-1868$

Signature: no signature

Dimensions: 17.8 × $23.2 \mathrm{~cm}$

Inscriptions: verso on print (ink from $19^{\text {th }}$ century hand): Villages

References: Roberta Wue, Picturing Hong Kong: Photography 1855-1910, 95.

Notes: 


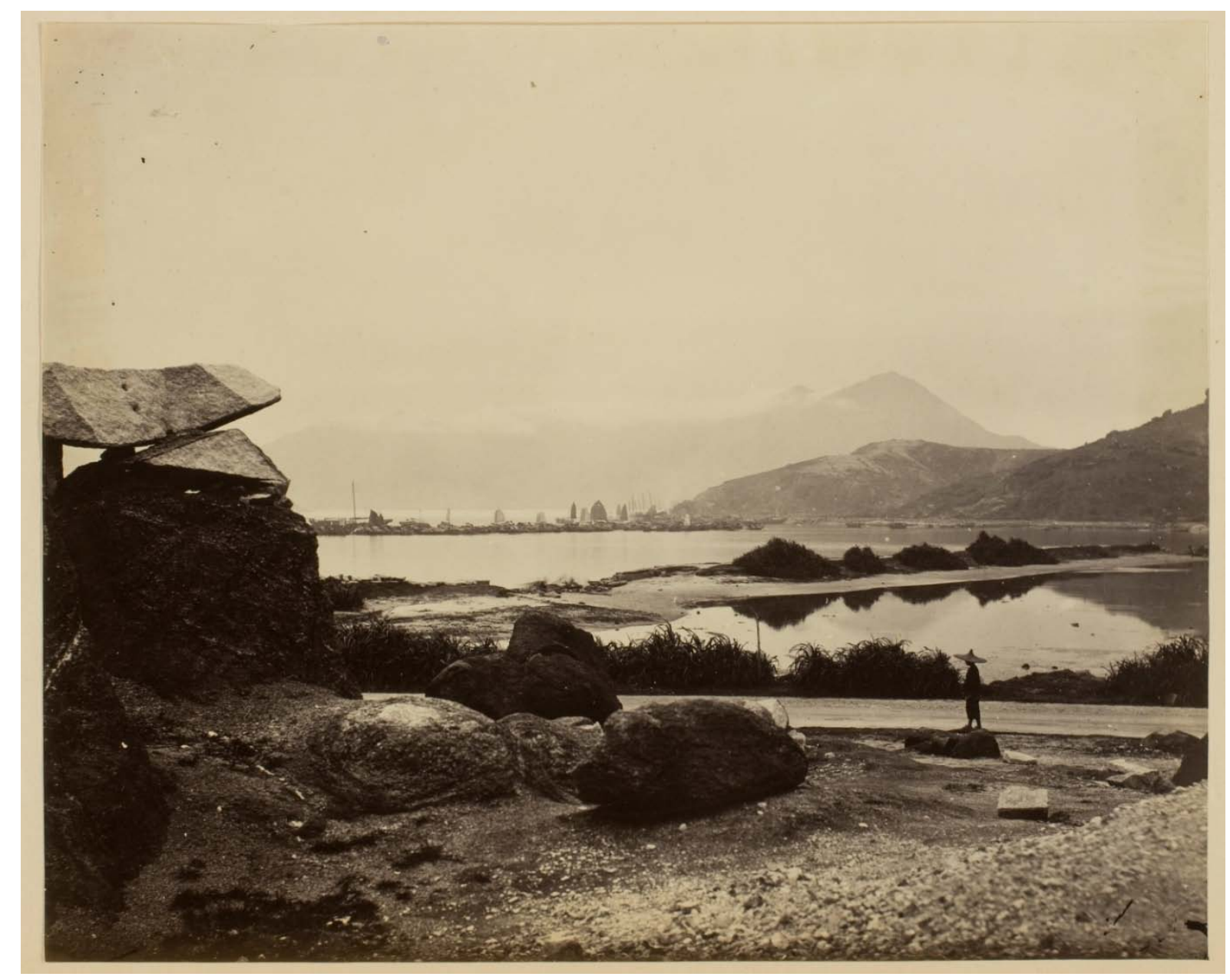

Accession No.: 1973:0219:0107

Page No.: 145

Date: $1862-1868$

Signature: no signature

Dimensions: 17.8 x $22.3 \mathrm{~cm}$

Inscriptions: recto on album page (ink from $19^{\text {th }}$ century hand): Causeway Bay verso on print (ink from $19^{\text {th }}$ century hand): Causeway Bay

References: Clark Worswick, Imperial China: Photographs 1850-1912, 101.

Roberta Wue, Picturing Hong Kong: Photography 1855-1910, 73.

Notes: Causeway Bay is located on Hong Kong Island. 


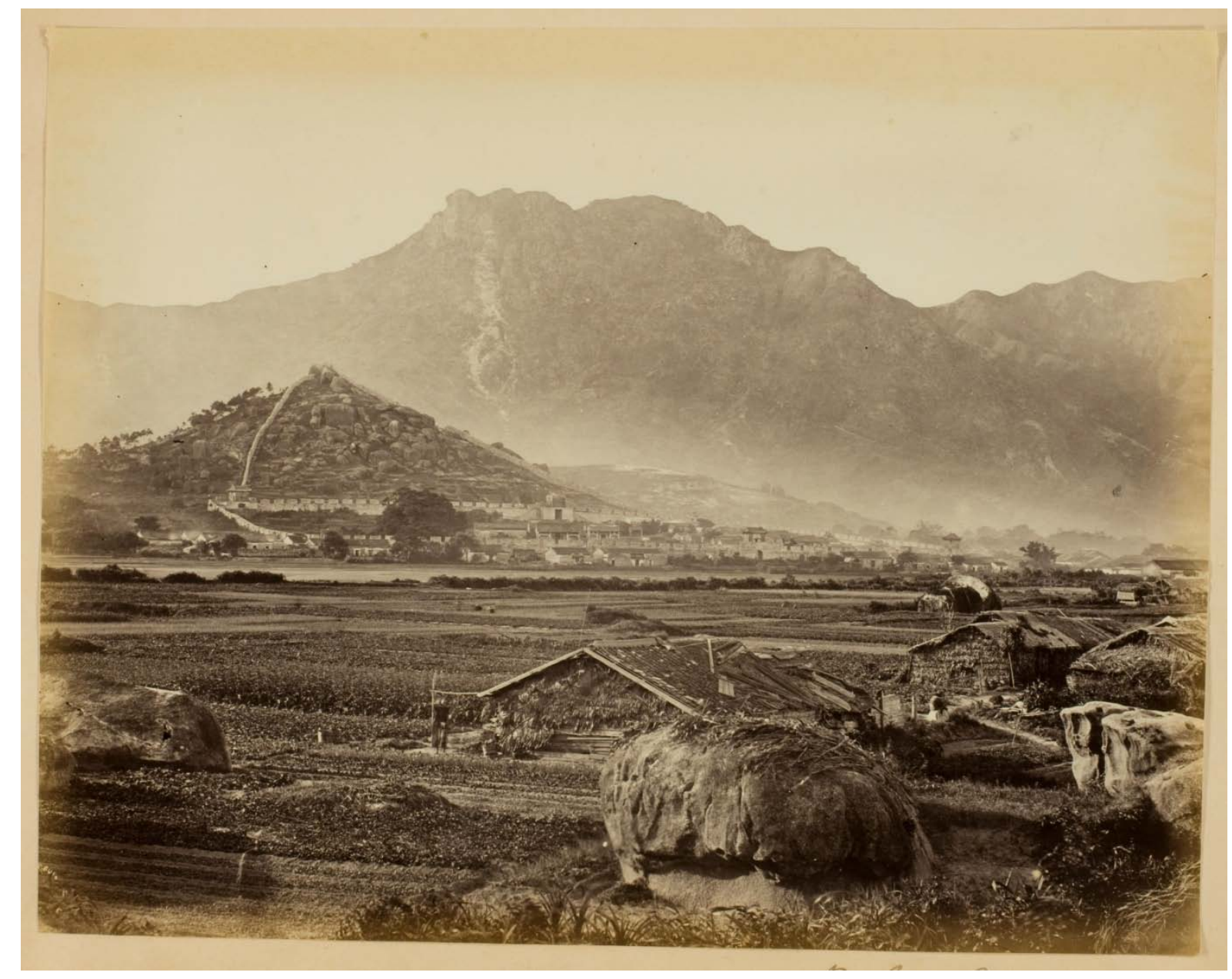

Accession No.: 1973:0219:0108

Page No.: 147

Date: $1862-1868$

Signature: no signature

Dimensions: 21.3 x $26.8 \mathrm{~cm}$

Inscriptions: recto on album page (ink from $19^{\text {th }}$ century hand): Kowloon City verso on print (ink from $19^{\text {th }}$ century hand): Kowloon City

References: John Thomson, Through China with a Camera, 17, Kowloon City, Mainland, Opposite Hong Kong.

Notes: Kowloon City is an area in Kowloon, Hong Kong. 


\section{Bibliography}

\section{Photographer John Thomson and Resources for Matching the Images}

Beach, Rev. William Roberts. The Visit of His Royal Highness the Duke of Edinburgh to Hong Kong in 1869. $2^{\text {nd }}$ ed. Hong Kong: Noronha and Sons, Government Printers, 1870.

Beijing World Art Museum. China Through the Lens of John Thomson 1868-1872. Bangkok: River Books Press: 2010.

Center for Creative Photography. "From the Archives: The Antiquities of Cambodia by John Thomson.” The Archives: Center for Creative Photography 25 (1988): 40-47.

Lehr, Janet. “John Thomson (1837-1921).” History of Photography 4.1 (1980): 67-71.

Library of Congress: Prints \& Photographs Online Catalog. Accessed July 11, 2014. http://www.loc.gov/pictures/search/?q=LOT\%204339 (LOT 4339).

Massachusetts Institute of Technology. "Visualizing Cultures.” Accessed April 4, 2014. http://ocw.mit.edu/ans7870/21f/21f.027/home/index.html.

National Library of Scotland. “The Photographs of John Thomson.” Accessed November 11, 2013. http://digital.nls.uk/thomson/index.html.

Ovenden, Richard. John Thomson (1837-1921) Photographer. Edinburgh: National Library of Scotland, 1997.

Parker, Elliott S. “John Thomson, 1837-1921: RGS Instructor in Photography.” Geographical Journal 144 (1978): 463-71.

Schupbach, William. “Focusing on History in Hong Kong.” Accessed April 4, 2014. http://blog.wellcomelibrary.org/2013/12/focusing-on-history-in-hong-kong/.

Smith, Adolphe. Street Life in London. New York: Benjamin Blom, INC., 1969.

Thomson, John. “Across Siam to Cambodia-I.” in Illustrated Travels: A Record of Discovery, Geography, and Adventure, edited by H. W. Bates, Vol.1, 307-10. London: Cassell, Petter, \& Gaplin, 1875.

"Across Siam to Cambodia." in Illustrated Travels: A Record of Discovery, Geography, and Adventure, edited by H. W. Bates, Vol.2, 43-44. London: Cassell, Petter, \& Gaplin, 1876.

“An Anamese Village.” China Magazine 1 (1868): 123-24. Accessed April 4, 2014. http://babel.hathitrust.org/cgi/pt?id=mdp.39015007035044;view=1up;seq=1.

“Hak-Kas.” China Magazine 1 (1868): 134-36.

“An Anamese Chief.” China Magazine 1 (1868): 150-51. 
“An Anamese Scholar.” China Magazine 1 (1868): 180-81.

“Chinese House at Cholon.” China Magazine 2 (1868): 166-67.

“The Cambodian Ruins (Part One).” China Magazine 2 (1868): 17-19.

“Three Pictures in Wong-nei-chung.” China Magazine 2 (1868): 52-56.

“The Cambodian Ruins (Part Two).” China Magazine 2 (1868): 80-82.

China, The Land and Its People: Early Photographs. Hong Kong: J. Warner

Publications, 1977.

— “Hong Kong Photographers.” British Journal of Photography 19 (1872): 569, 591-2.

Illustrations of China and Its People. London: S Low, Marston, Low and Searle, 1874.

“The Antiquities of Cambodia.” Journal of the North China Branch of the Royal Asiatic Society (1873): 197-204. Accessed April 4, 2014.

http://books.google.com/books?id=7YUuAAAAYAAJ\&pg=PA197\&hl=zh-CN\&so urce=gbs_toc_r\&cad=4\#v=onepage\&q\&f=false.

The Antiquities of Cambodia: A Series of Photographs Taken on the Spot. Edinburgh: Edmonston \& Douglas, 1867.

The Land and the People of China: A Short Account of the Geography, History, Religion, Social Life, Art, Industries, and Government of China and Its People. London: Society for promoting Christian knowledge; New York: Pott, Young \& Co., 1876.

The Inmost Shrine: A Photographic Odyssey of China, 1873. Delray Beach, FL: Levenger Press, 2009.

- The Straits of Malacca, Indo-China, and China; or, Ten Years' Travels, Adventures, and Residence Abroad. Illustrated with upwards of sixty wood engravings by J. D. Cooper, from the author's own sketches and photographs. London: Sampson Low, Marston, Low, \& Searle, 1875. Accessed April 4, 2014.

https://archive.org/details/straitsofmalacca00thomuoft.

— Through China with a Camera. Westminster: A. Constable \& Co., 1898. Accessed April 4, 2014. https://archive.org/details/throughchinawit00thomgoog.

Warner, John. “John Thomson: Compassionate Photographer.” Arts of Asia 6.3 (1976): 42-53.

White, Stephen. John Thomson: Life and Photographs. London: Thames and Hudson, 1985. and Robert A. Sobieszek. John Thomson: A Window to the Orient. New York: 
Thames and Hudson, 1985.

UMass Amherst Libraries, Special Collections \& University Archives. "John Thomson Photograph Collection.” Accessed April 4, 2014.

http://www.library.umass.edu/spcoll/ead/muph002.html\#.

Wellcome Library Collection Catalogues. Accessed April 4, 2014. http://search.wellcomelibrary.org/iii/encore/search/C__SThomson\%2C\%20J.\%20\% 201837-1921_Ff\%3Afacetmediatype\%3Ak\%3Ak\%3APictures\%3A\%3A__Orightr esult__X0?lang=eng\&suite=cobalt.

Wellcome Collection. "John Thomson's China: A Scot who Travelled Throughout the Far East, Photographing Everyday Life.” Accessed May 25, 2014.

http://www.wellcomecollection.org/explore/time--place/topics/john-thomsons-china/ john-thomsons-china.aspx.

\section{Histories of Photography in Malaysia, Singapore, Ceylon, India, and China}

Beijing World Art Museum. Imperial City Impression: Old Peking Images in Western Prints. Beijing: Zhong Hua Book Company, 2009.

and Qin Feng Studio. Disturbed Dreams in the Ruins of the Garden: Ernst Ohlmer and Historical Images of Yuanmingyuan. Guilin: Guangxi Normal University Press, 2010.

Bennett, Terry. History of Photography in China, 1842-1860. London: Bernard Quaritch Ltd., 2009.

_ History of Photography in China, Western Photographers 1861-1879. London: Bernard Quaritch Ltd., 2010.

History of Photography in China, Chinese Photographers 1844-1879. London: Bernard Quaritch Ltd., 2013.

Busey, Samuel C. "Early History of Daguerreotype in the City of Washington." Records of the Columbia Historical Society (Washington, D. C.) 3 (1900): 81-95. Accessed May 13, 2014. http://www.daguerreotypearchive.org/texts/P9000001_BUSEY_WASHINGTON_1 900.pdf.

Cody, Jeffrey W, and Frances Terpak. "Through A Foreign Glass: The Art and Science of Photography in Late Qing China.” In Brush and Shutter: Early Photography in China, edited by Jeffrey W. Cody and Frances Terpak, 33-68. Los Angeles: Getty Research Institute, 2011.

Dehejia, Vidya, and Charles Allen. India through the Lens: Photography 1840-1911. Washington, D.C.: Freer Gallery of Art and Arthur M. Sackler Gallery, Smithsonian Institution in association with Mapin Publishing, Ahmedabad, 2000. 
Edwards, Elizabeth, and Janice Hart, eds. Photographs Objects Histories: On the Materiality of Images. New York: Routledge, 2004.

Falconer, John. A Vision of the Past: A History of Early Photography in Singapore and Malaya; The Photographs of G. R. Lambert \& Co., 1880-1910. Singapore: Times Editions, 1987.

“John Ashton Papillon: An Amateur Photographer in China 1858-60.” The Photographic Collector 3.3 (1982): 346-62.

Gimon, Gilbert. “Jules Itier, Daguerreotypist.” History of Photography 5.3 (1981): 225-44.

Ginsburg, Henry. Thai Art and Culture: Historic Manuscripts from Western Collections. Honolulu: University of Hawaii, 2000.

Goodrich, L. Carrington, and Nigel Cameron. The Face of China as Seen by Photographers \& Travelers 1860-1912. New York: Aperture Foundation, 1978.

Hacker, Arthur, and Wattis Fine Art. "Hong Kong, A Rare Photographic Record of the 1860s.” Accessed April 4, 2014.

http://www.wattis.com.hk/cartographers/author-photographer/.

Hannavy, John, ed. Encyclopedia of Nineteenth-Century Photography. New York: Taylor \& Francis Group, 2008.

Harris, David. Of Battle and Beauty: Felice Beato's Photographs of China. Santa Barbara, CA: Santa Barbara Museum of Art, 1999.

Hu Zhichuan.胡志川, and Chen Shen.陈申, Zhongguo jiuying lu: 1840-1919. 中国旧影录: 1840-1919 [Early Chinese Photographs, 1840-1919]. Beijing: China Photographic Publishing House, 1999.

Lacoste, Anne, ed. Felice Beato: A Photographer on the Eastern Road. Los Angeles: The J. Paul Getty Museum: 2010.

Lai, Edwin K. “Liang Shitai, Chinese Court Photographer from Hong Kong.” In Responding to Art: From, Content, and Context, edited by Robert Bersson, 160-1. New York: McGraw-Hill, 2003.

"The History of the Camera Obscura and Early Photography in China.” In Brush and Shutter: Early Photography in China, edited by Jeffrey W. Cody and Frances Terpak, 19-32. Los Angeles: Getty Research Institute, 2011.

Lin, Jing. The Photographs of Cixi in the Collection of the Palace Museum. Beijing:

Forbidden City Publishing House, 2002.

Liu, Gretchen. “Archival Collections of Asia Photographs in Singapore’s National Archives, National Library and National Museum.” Archives 4.1 (2013). Accessed May 17, 2014.

http://quod.lib.umich.edu/t/tap/7977573.0004.110/--archival-collections-of-asia-phot 
ographs-in-singapores?rgn=main;view=fulltext.

Masselos, Jim, and Narayani Gupta. Beato’s Delhi 1857 and Beyond. Delhi: Ravi Dayal, 2011.

Moh, Alex, Li-En Chong, and Balai Seni Lukis Negara. Malaysian Photography: History and Beyond. Kuala Lumpur: National Art Gallery Malaysia, 2004. Accessed May 17, 2014. https://www.nikonclub.com.my/pages/Insights.aspx?cid=30.

Moore, Oliver. “Zou Boqi on Vision and Photography in Nineteenth-Century China.” In The Human Tradition in Modern China, edited by Kenneth J. Hammond and Kristin Stapleton, 33-54. Lanham, MD: Rowman \& Littlefield, 2008.

Morris, Rosalind C. ed. Photograhies East: The Camera and Its Histories in East and South East Asia. Durham: Duke University Press, 2009.

Nasution, Khoo Salma. More than Merchants: A History of the German-Speaking Community in Penang, 1800s-1940s. Penang: Areca Books, 2006.

Oliphant, Laurence. Narrative of the Earl of Elgin's Mission to China and Japan in the Years 1857, '58, '59. Edinburgh: William Blackwood \& Sons, 1859. Accessed May 13, 2014. https://archive.org/details/narrativeearlel03olipgoog.

Osman, Colin. “In Search of Thomson Child.” British Journal of Photography 6729 (1989): 16-17, 6730 (1989): 18-19, 6732 (1989): 14-15.

“Thomson Child (1841-1898) Photographer of Peking.” The Photo Historian 84 (1989): 3-5.

Pearce, Nick. Photographs of Peking, China 1861-1908: An Inventory and Description of the Yetts Collection at the University of Durham: Through Peking with a Camera. Lewiston, NY: The Edwin Mellen Press, 2005.

“A Life in Peking: The Peabody Albums.” History of Photography 31.3 (2007): 276-87.

Raheem, Ismeth, and Percy Colin Thomè. Images of British Ceylon: Nineteenth Century Photography of Sri Lanka. Singapore: Times Editions, 2000.

Stambler, Benita. “Maintaining the Photographic Legacy of Ceylon.” Archives 4.1 (2013). Accessed May 17, 2014.

http://quod.lib.umich.edu/t/tap/7977573.0004.105/--maintaining-the-photographic-le gacy-of-ceylon?rgn=main;view=fulltext.

Thiriez, Regine. Barbarian Lens: Western Photographers of the Qianlong Emperor's European Palaces. Amsterdam: Gordon and Breach, 1998.

Thomas, G. History of Photography, India, 1840-1980. Hyderabad: Andhra Pradesh State Akademi of Photography, 1981. 
Toh, Jason. Singapore Through $19^{\text {th }}$ Century Photographs. Singapore: Editions Didier Millet, 2009.

Warner, John. Fragrant Harbour: Early Photographs of Hong Kong. Hong Kong: John Warner Publications, 1977.

Welch, Stuart Cary, ed. India: Art and Culture, 1300-1900. New York: Metropolitan Museum of Art, Holt, Rinehart and Winston, 1985.

Worswick, Clark, ed. Sheying: Shades of China, 1850-1900. New York: D.A.P., 2008. and Ainslie Embree. The Last Empire: Photography in British India, 1855-1911. Millerton, NY: Aperture, 1976.

and Jonathan D. Spence. Imperial China: Photographs 1850-1912. New York: Pennwick, 1978.

Wright, Arnold, and H. A. Cartwright, ed. Twentieth Century Impressions of British Malaya: Its History, People, Commerce, Industries, and Resources. London, Durban, Colombo, Perth (W. A.), Singapore, Hong Kong, and Shanghai: Lloyd's Greater Britain Publishing Company, limited, 1908. Accessed May 17, 2014. https://archive.org/details/cu31924023134368.

Wu, Hung. "Inventing a 'Chinese' Portrait Style in Early Photography: The case of Milton Miller.” In Brush and Shutter: Early Photography in China, edited by Jeffrey W. Cody and Frances Terpak, 69-90. Los Angeles: Getty Research Institute, 2011.

Wue, Roberta. Picturing Hong Kong: Photography 1855-1910. New York: Asia Society Galleries and George Braziller, 1997.

\section{Photo Album Scholarship}

Bann, Stephen, ed. Art and the Early Photographic Album. Washington, D.C.: National Gallery of Art, 2011.

Coke, Van Deren. Photographs, Photographically Illustrated Books and Albums in the UNM Libraries, 1843-1933. Albuquerque: University of New Mexico, 1977.

Curtis, Verna Posever. Photographic Memory: The Album in the Age of Photography. New York: Aperture, 2011.

George Eastman House. “The Boyer Collection.” Image, Journal of Photography of the George Eastman House 2.7 (1953): 41-48.

George Eastman House's collection management system. (constituents name Alden Scott Boyer [constituents number 8103]; accessed June 21, 2014).

(object name John Thomson Scrapbook [accession number 1973:0219:0001-0123]; accessed November 8, 2013). 
Krauss, Rolf. “Travel Reports and Photography in Early Photographically Illustrated Books.” History of Photography 3.1 (1979): 15-30.

Langford, Martha. Suspended Conversations: The Afterlife of Memory in Photographic Albums. Montreal: McGill-Queen's University Press, 2001.

Levine , Barbara. Snapshot Chronicles: Inventing the American Photo Album. New York: Princeton Architectural Press, 2006.

Roth, Andrew. The Open Book: A History of the Photographic Book from 1878 to the Present. Göteborg: Hasselblad Center, 2004.

\section{History of Malaysia, Singapore, Ceylon, India, and China}

Cavaliero, Eric. “Pedder Street Was Where It all Happened.” August 13, 1998. Accessed May 23, 2014.

http://www.thestandard.com.hk/news_detail.asp?pp_cat=\&art_id=40111\&sid=\&con _type=1\&d_str=19980813\&sear_year=1998.

Contai Information Point. “Cyclones and Floods at Contai.” Accessed February 10, 2014. http://www.contai.info/cyclone1.php.

Gastrell, James Eardley, and Henry Francis Blanford. Report on the Calcutta Cyclone of the 5th October 1864. Calcutta: O.T. Cutter Military Orphan Press, 1866. Accessed May 25, 2014. https://archive.org/details/reportoncalcutt00blangoog.

Henandi Wenhua Xueshe 河南地文化学社 [Henan Culture Society]. "Yizhang Guangzhou laozhaopian yinfa de dili yian”一张广州老照片引发的地理疑案 [A Geographical Mystery from an Old Canton Photo]. Xinxi Shibao 信息时报 [Information Times], June 29, 2013. Accessed February 10, 2014. http://informationtimes.dayoo.com/html/2013-06/29/content_2301981.htm.

Hooker, Virginia Matheson. A Short history of Malaysia: Linking East and West. Crows Nest: Allen \& Unwin, 2003.

Leisure and Cultural Services Department. "Hong Kong Zoological and Botanical Gardens.” Accessed May 23, 2014. http://www.lcsd.gov.hk/parks/hkzbg/en/index.php.

Open Library. “Documents Connected with the Hong Kong Stamp Act.” Accessed May 27, 2014.

https://openlibrary.org/works/OL5425400W/Documents_connected_with_the_Hong _Kong_Stamp_Act_passed_in_the_Legislative_Council_Sept._5th.

St John's Cathedral. “A Brief History of St John's Cathedral.” Accessed May 23, 2014. http://www.stjohnscathedral.org.hk/Page.aspx?lang=1\&id=97. 